\title{
VERIDIANA MUNFORD
}

\section{DIVERSIDADE SOROLÓGICA E MOLECULAR DE ROTAVÍRUS IDENTIFICADOS EM HUMANOS EM SÃO PAULO, BRASIL}

Tese (Doutorado) apresentada ao Instituto de Ciências Biomédicas da Universidade de São Paulo, para obtenção do título de Doutor em Ciências (microbiologia). 


\section{VERIDIANA MUNFORD}

\section{DIVERSIDADE SOROLÓGICA E MOLECULAR DE ROTAVÍRUS IDENTIFICADOS EM HUMANOS EM SÃO PAULO, BRASIL}

Tese (Doutorado) apresentada ao Instituto de Ciências Biomédicas da Universidade de São Paulo, para obtenção do título de Doutor em Ciências (microbiologia).

Área de concentração:

Microbiologia

Orientadora:

Prof. Dra. Maria Lúcia Rácz 
Aos Meus Pais Marilene e Willian, que juntos me ensinaram o valor do AMOR, do RESPEITO e a importância do conhecimento para 0 crescimento humano.

Ao Ricardo, o homem que sempre amei e que se transformou no companheiro pelo qual estou MUITO APAIXONADA.

Aos Meus filhos MARIANA e GUILHERME vocês São o meu NORTE, meu OXIGÊNIO, minha VIDA!! "Perdão por ter estado tão ocupada nos últimos meses...agora temos muitos combinados para cumprir"

Dan e Max, você são a minha inspiração! 


\section{AGRADECIMENTOS ESPECIAIS}

\section{Ao Ricardo,}

Que me incentivou a começar esta jornada, e que nos últimos dias passou noites em claro, cuidou da casa e das crianças, pondo a "mão na massa" nas

coisas mais chatas e braçais.....

Guiga e Mari Obrigada pela paciência e compreensão 


\title{
AGRADECIMENTOS ESPECIAIS
}

\begin{abstract}
À Maria Lúcia Rácz,
Que possibilitou em todos os sentidos a realização deste trabalho. Acreditou e lutou para que eu pudesse fazer esta pós-graduação.

E que durante todos estes anos de convivência me ensinou muito, contribuindo dia a dia para que eu me tornasse profissional que sou hoje.

Agradeço ainda sua dedicação e amizade, ao longo de todos esses anos de convivência.
\end{abstract}




\section{AGRADECIMENTOS}

Ao finalizar este estudo agradeço a todos que, direta ou indiretamente, contribuíram para sua realização e, de maneira especial:

Às minhas amigas Suzana e Wilia que mesmo nem sempre presentes, sempre estiveram no meu coração e com as quais eu sempre pude contar para ouvir e ajudar.

À Regina Marques grande amiga, cujas conversas vão de filogenia a teologia.

Aos meu amigos do laboratório, Thabata, Carla, Norma, Hérika e Hugo cuja a energia positiva e alegria fizeram meus dias de trabalho bem mais leves, e que me fizeram tanta falta no último ano.

Aos amigos do Instituto Pasteur de São Paulo, Pedro, Rafael e Juliana que me ensinaram tudo de sequenciamento me ajudaram, deram muito do seu tempo e sempre com muito bom humor.

A Dra. Ivanette Kotait, diretora do Instituto Pasteur, que me possibilitou o treinamento e o uso do analisador automático de DNA, nas etapas finais do trabalho, deixando as portas do Instituto sempre abertas para mim.

Ao amigos Carlos Augusto e Anamaria, amigos sempre solícitos e colaborativos ajudando além das suas funções.

À minhas novas amigas Fernanda. Juliana, Daniela, Joselma, Tatiana, Paty e Patrícia que me acolheram sempre com um café quentinho neste ultimo ano, e me ajudaram a atravessar esta fase complicada.

Às minhas amigas Telma e Natasha que viveram e compartilharam comigo muitos momentos, me ouvindo e me apoiando.

Ao Prof. Dr.Carlos Frederico Menck, e Prof. Dr Luiz Carlos Ferreira, que foram chefes do Departamento de Microbiologia durante meu doutoramento, e me apoiaram e acreditaram na minha capacidade.

Aos Professores do Departamento de Microbiologia Jorge Timenetsky pelo uso constante do seu foto documentador.

Aos funcionários do Instituto de Ciências Biomédicas da Universidade de São Paulo, Antônia Aparecida Rodrigues, Elaine Fátima Santos, José Gomes, Severina Carolina Elza e Eliete, pelo suporte técnico realizado pelo SAT, indispensável em todas as pesquisas do Departamento de Microbiologia. 
Às funcionárias da Secretaria de Pós-Graduação e de Departamento do Instituto de Ciências Biomédicas II, da Universidade de São Paulo, Alice M. Shimabuku, Naíde R. Farripas, Anamaria França Seu Duvaldo e Vera Monesi pelo trabalho e dedicação ao departamento sem este suporte ficaríamos enrolados na teia da burocracia da USP.

À Antonieta Grimaldi, que me ajudou a atravessar com uma certa sanidade por estes e outros momentos onde o desespero parecia a única alternativa.

Ao Dr. Danilo Baltieri que me deu a coisa certa na dose certa para continuar vendo o mundo na perspectiva correta.

Às Bibliotecárias Eva pelo carinho com que me ajudou a passar por mais uma etapa burocrática e Maria José pelas orientações valiosas e pelo auxílio na revisão das referências bibliográficas deste trabalho.

Aos meus sogro e sogra Dr. Cestari e Jaci, que sempre me motivaram e estiveram ao lado da família dando o suporte que precisamos para concretizar este sonho.

À Bete e à Sandra que cuidaram das coisas lá em casa para que eu pudesse cuidar das coisas aqui no laboratório.

À Fundação de Amparo à Pesquisa do Estado de São Paulo (FAPESP), pela concessão de bolsa de doutorado e pelo apoio financeiro a esta pesquisa. 
“CONTINUE A NADAR....”

Dory

Filme: "Procurando Nemo"

Walt Disney Pictures 
"After all, tomorrow is another day" Scarlett O'Hara 


\begin{abstract}
From 187 fecal samples collected from outpatients at Hospital Universitário (HU)/ USP, between 1994 to 1996, 54 (28,9\%) were positive for rotavirus. Positive samples were submitted to electropherotyping, subgrouping, and G serotype. Electropherotypes were characterized as nine different long genome profiles, one short and one unusual profile. Subgroup II and G2 serotype were the most frequently found and three samples showed mixed serotypes. Rotavirus samples and an additional 163 positive fecal samples, collected in a private laboratory in 2000, were $G$ and P genotyped. Genotypes G2P[4] and G1P[8] were the most frequently found in 1994-1996 and, in 2000, G1P[8] and G9P[8] were the most frequent. Genotype G3 and G4 were detected as minor strains in both years. For HU, G genotype mixtures were found in 20 (38.5\%) samples and $P$ mixtures were found in 16 (29.6\%). No mixtures were identified in 2000. Nucleotide sequencing and phylogenetic analysis of 18 P[10] samples by RT-PCR showed 90.7 to $98.0 \%$ homology with the P[8] prototype.
\end{abstract}




\section{RESUMO}

De um total de 187 amostras fecais coletadas no ambulatório do Hospital Universitário/USP, entre 1994 a 1996, 54 (28,9\%) foram positivas para rotavírus. Entre as amostras caracterizadas por EGPA foram identificados nove perfis eletroforéticos longos, dois curtos e um tipo não usual. O subgrupo II e o sorotipo $\mathrm{G} 2$ foram os mais freqüentemente identificados. Foram caracterizadas três amostras com misturas de sorotipos. As amostras positivas e mais 163 amostras, coletadas em um laboratório particular, em 2000, foram genotipadas. Os genótipos G2P[4] e G1P[8] foram os mais freqüentes nos anos de 1994-1996 e G1P[8] e G9P[8], os mais freqüentes em 2000. Os genótipos G3 e G4 foram detectado em menor freqüência. No HU, 20 (38,5\%) amostras foram caracterizadas como misturas de genótipos G e 16 (29,6\%), como misturas de genótipos P; não foram identificadas misturas em 2000. Dezoito amostras foram caracterizadas como $\mathrm{P}[10]$ por RT-PCR mas a análise da seqüência de nucleotídeos mostrou uma homologia de 90,7 a 98,0\% com a amostra padrão $P[8]$. 


\section{LISTA DE FIGURAS}

Figura 1: Imagem de partícula de rotavírus observada ao microscópio eletrônico (aumento de 163.600X).Fonte: http://www.ncbi.nlm.nih.gov/ICTVdb/ICTVdB

Figura 2: Estrutura tridimensional da partícula de rotavírus. A numeração indica os eixos de simetrias. Adaptado de PRASAD e ESTES, 2000; LAWTON et al., 1997.

Figura 3: Estrutura da partícula de rotavírus, correspondência entre os segmentos de dsRNA (esquerda), diagrama esquemático (centro) e reprodução do vírus por crio-eletromicroscopia (direita). Localização das proteínas estruturais na partícula de rotavírus do grupo A. NSP, proteína não estrutural. Fonte: de GENTSCH, et al. 2005.

Figura 4: Representação esquemática da estrutura dos genes de rotavírus, segundo publicação das seqüências dos genes 1 a 11. Fonte: ESTES e KAPIKIAN, 2007).

Figura 5: Esquema da replicação dos rotavírus. Fonte: ESTES, 2001.

Figura 6: Combinações genótipos $P$ e $G$ de rotavírus isolados em crianças com diarréia, incluindo as combinações pouco usuais, distribuição regional, etária e espécie comumente identificada. Fonte: GENTSCH et al. 2005

Figura 7: Representação esquemática do nono ou oitavo segmento genômico dos rotavírus, que codifica para a glicoproteína VP7, com a localização das regiões variáveis, posição dos primers, o tamanho respectivo dos segmentos amplificados e genótipos a que correspondem.

Figura 8: Representação esquemática do quarto segmento genômico dos rotavírus, que codifica para a proteína VP4, com a localização das regiões variáveis, posição dos primers o tamanho respectivo dos segmentos amplificados e genótipos a que correspondem.Figura 9: Distribuição das amostras positivas para rotavírus de acordo com a faixa etária dos pacientes em São Paulo, Brasil no período de janeiro a dezembro de 2000.

Figura 10: Distribuição sazonal e número de amostras positivas identificadas nas amostras coletadas em São Paulo, Brasil no período março de 1994 a fevereiro de 1996.

Figura 11: Número de amostras positivas identificadas de fevereiro a outubro em São Paulo, Brasil no período de janeiro a dezembro de 2000. 
Figura 12: Eletroforese em gel de Poliacrilamida de amostras representativas dos rotavírus identificados em São Paulo no período estudado de 1994 a 1996. Canaletas 1, 5 e 6: controle positivo (SiRV-A/SA11); canaleta 2: amostra HuRV-A/ICB1375, padrão incomum; canaleta 3: amostra HuRV-A/ICB410, padrão "curto"; canaleta 4, amostra HuRV-A/ICB1410, padrão "longo"; canaleta 7 amostra HuRV-A/ICB1340 padrão "longo"; canaleta 8 amostra HuRVA/ICB1343 padrão "longo" com mistura de eletroferótipo, segmentos extras indicados.

Figura 13: Eletroforese em gel de poliacrilamida de amostras representativas dos rotavírus identificados em São Paulo no ano de 2000. Canaletas 1 e 10: controle positivo (SiRV-A/SA11). Perfil L1: canaletas 2 (HuRv/ICB3325); canaletas 3 (HuRV-A/ICB3332). Perfil L2: canaletas 4 (HuRv/ICB3337); canaletas 5 (HuRV-A/ ICB3371). Perfil L3: canaletas 6 (HuRV-A/ICB3368). Perfil L4: canaleta 7 (HuRV-A/ICB3374). Perfil L5 canaleta 8 (HuRVA/ICB3329); canaleta 9 amostra (HuRV-A/ICB337).

Figura 14: Distribuição mensal dos sorotipos $G$ identificados entre as amostras positivas para rotavírus coletadas em São Paulo, no período março de 1994 a fevereiro de 1996.

Figura 15: Caracterização molecular por RT-PCR de genótipos G, com primers únicos. Canaletas 1 e 20: padrão de peso molecular 100pb. Canaleta 2: ICB1269 G3. Canaletas 3 e 4: ICB1277 G2 e G4. Canaletas 5 e 6: ICB1299 G2 e G4. Canaletas 7 e 8: ICB1338: G4 e G9. Canaletas 9 e 10: ICB1340 G2 e G4. Canaletas 11 e 12: ICB1344 G9 e G5. Canaleta 13 e 14: ICB1345 G4 e G9 negativa. Canaletas 15, 16 e 17: ICB1347 G2, G4 e G9. Canaleta 18: $\mathrm{H}_{2} \mathrm{O}$ controle negativo. Canaleta 19: amostra padrão HuRv-A/RV4: G1.Figura 16: Caracterização molecular por RT-PCR com o pool de primers de genótipos $\mathrm{P}$. As amostras ICB1269, ICB1277, ICB1301 apresentam misturas P[4]P[6M]P[8]; as amostras ICB1340 e ICB1362, misturas de P[8]P[4]; a amostra ICB1274 $\mathrm{P}[4]$; as amostras ICB1296, ICB1327, ICB1357 P[8]; as amostras ICB1328, ICB1363 negativas. $\mathrm{H}_{2} \mathrm{O}$ controle negativo. Padrão de peso molecular 100pb. Amostra padrão HuRV-A/ST3 P[6].

Figura 17: Caracterização molecular por RT-PCR de genótipos P[10], com primers Con3 e 5T1. $\mathrm{H}_{2} \mathrm{O}$ controle negativo. Padrão de peso molecular 100pb.

Figura 18: Analise filogenética das seqüências parciais de nucleotídeos que codificam a proteína VP4 de 26 amostras protótipos do genótipo P, comparada as 18 amostras seqüenciadas. Dendrograma construído a partir do método de bootstrap utilizando o programa MEGA 3.1. O número na lateral da árvore representa. Comprimento do ramo indica distância entre as seqüências.

Figura 19: Alinhamento dos fragmentos de VP4, na região do primer 1T1, específico para $P[8]$, com as seqüências reversas complementares deste primer. Os resíduos diferentes do primer nas seqüências $A$ e $B$ são representados por -. A seqüência de nucleotídeos da amostra ICB3374 representa 17 amostras. E a seqüência de nucleotídeos da amostra ICB3368, é representada abaixo. 
Figura 20: Alinhamento dos fragmentos de VP4, na região do primer 5T1, específico para $P[10]$, com as seqüências reversas complementares deste primer. Os resíduos diferentes do primer nas seqüências $A, B$ e $C$ são representados por -. A seqüência de nucleotídeos da amostra ICB3369 representa as 14 amostras do subtipo P[8]-1 e da amostra ICB3374, as quatro amostras do subtipo P[8]-2. 


\section{LISTA DE TABELAS}

Tabela 1. Segmentos genômicos do rotavírus, as proteínas por eles codificadas e suas funções.

Tabela 2: Classificação de sorotipos e genotipos $G$ de rotavírus do grupo A. Cepas e espécies onde estas amostras foram identificadas. Fonte: ESTES e KAPIKIAN, 2007

Tabela 3: Classificação de sorotipos e genotipos $P$ de rotavírus do grupo $A$. Cepas e espécies onde estas amostras foram identificadas. Fonte: ESTES e KAPIKIAN, 2007; MARTELLA et al., 2007.

Tabela 4: Amostras padrão de rotavírus, cultivadas no Laboratório de Virologia, Departamento de Microbiologia, ICB-USP, com as respectivas classificações de subgrupo, sorotipos e genótipos $G$ e $P$.

TABELA 5: Seqüência de nucleotídeos dos primers utilizados na caracterização de genótipos $\mathrm{P}$ da proteína VP4, suas respectivas posições de anelamento; amostra usada como protótipo de genótipo e referência bibliográfica.

TABELA 6: Seqüência de nucleotídeos dos primers utilizados na caracterização do genótipo G da proteína VP7, suas respectivas posições de anelamento; amostra usada como protótipo de genótipo e referencia bibliográfica.

Tabela 7: Ciclagem utilizada para a "semi-nested - RT-PCR" utilizando os primer descritos por DAS et al. 1994; GOUVEA et al. 1990, 1994a e b; GENTSCH et al. 1992

Tabela 8: Tamanho dos segmentos produzidos pela "semi nested RT-PCR" para cada um dos genótipos $\mathrm{G}$ de rotavírus testados e seus respectivos primers.

Tabela 9: Tamanho dos segmentos produzidos pela "semi nested RT-PCR" para cada um dos genótipos $\mathrm{P}$ de rotavírus testados e seus respectivos primers.

Tabela 10: Padrões usados para comparação da seqüência de DNA, seus respectivos genótipos e número de depósito no GenBanck.

Tabela 11: Distribuição das amostras positivas para rotavírus de acordo com a faixa etária das crianças em São Paulo, Brasil no período de março de 1994 a fevereiro de 1996.

Tabela 12: Comparação da porcentagem de amostras positivas identificadas por faixa etária das crianças de zero a cinco anos de idade, no dois grupos de amostras estudadas em São Paulo, Brasil nos períodos de março de 1994 a fevereiro de 1996 e fevereiro a outubro de 2000.

Tabela 13: Subgrupo, sorotipo e perfil eletroforético obtidos na caracterização das 54 amostras de rotavírus obtidas em São Paulo, no período de março de 1994 a fevereiro de 1996. 
Tabela 14: Número de amostras identificadas com cada genótipo considerados isoladamente, através da técnica semi-nested RT-PCR nas amostras de rotavírus identificadas em São Paulo, entre 1994 e 1996.

Tabela 15: Resultado total da genotipagem por RT-PCR das amostras de rotavírus identificadas em São Paulo, Brasil entre 1994 e 1996.

Tabela 16: Resultado total da genotipagem por RT-PCR das amostras de rotavírus identificadas em São Paulo, em 2000 


\section{SUMÁRIO}

Página

1 Introdução

1.1 Histórico $\quad 20$

1.2 Aspectos gerais 22

1.3 Estrutura 22

3.4 Replicação 31

3.5 Classificação sorológica 34

$\begin{array}{lll}3.6 & \text { Patogenese } & 39\end{array}$

3.7 Diagnóstico laboratorial $\quad 42$

$\begin{array}{lll}3.8 & \text { Imunidade } & 45\end{array}$

3.9 Epidemiologia $\quad 47$

3.10 Prevenção e controle 53

2 Objetivos $\quad 58$

3 Material e Métodos

3.1 Amostras de fezes 59

3.2 Amostras Padrão 59

3.3 Preparo da suspensão das amostras de fezes 60

3.4 Ensaio imunoenzimático para rotavírus e adenovírus (EIERA/FIOCRUZ) 61

3.5 Eletroforese de RNA de rotavírus em gel de poliacrilamida (EGPA) 63

3.6 Ensaio imunoenzimático para determinação de subgrupo 65

3.7 Ensaio imunoenzimático para determinação de sorotipo 67

3.8 Caracterização molecular de genótipos G e P 69

$\begin{array}{ll}3.9 \text { Sequenciamento genômico } & 74\end{array}$

4 Resultados $\quad 80$

5 Discusão 100

6 Conclusões $\quad 121$

$\begin{array}{ll}\text { Referências Bibliográficas } & 123\end{array}$ 


\section{INTRODUÇÃO}

\subsection{HISTÓRICO}

Os rotavírus têm sido apontados como um dos principais agentes etiológicos de gastroenterites virais em lactentes e crianças durante a primeira infância (PARASHAR et al., 2003; KANE et al., 2004). Além do homem, sua presença tem sido demonstrada apenas em animais vertebrados de várias espécies, tanto em animais domésticos como bovinos (VAN DER HEIDE et al., 2005; REIDY et al., 2006), suínos (ASENSI et al., 2006; RÁCZ et al., 2000), eqüinos (RÁCZ et al., 1993), cães (GABBAY, et al., 2003) entre outros (ESTES et al., 1983; MARTELLA et al., 2005; PISANELLE et al., 2005) e, além disso, os rotavírus também foram detectados em animais silvestres (PARRE et al., 2004; ESTES e KAPIKIAN, 2007).

A primeira descrição relacionada à etiologia das diarréias associadas a agentes infecciosos não bacterianos foi feita na década de 40 , quando Light e Hodes (1943) induziram diarréia em bezerros, após inoculação, por via oral, de filtrados de suspensões de fezes de crianças com gastroenterites (LIGHT e HODES, 1943). Em 1969, Mebus et al. demonstraram a associação entre a presença de partículas virais identificadas por microscopia eletrônica e o quadro clínico de diarréia em bezerros. Este quadro clínico foi reproduzido experimentalmente "in vivo", após a inoculação por via oral de filtrados de materiais fecais livres de bactérias (MEBUS et al., 1969).

Apesar da magnitude dos problemas causados pela diarréia infantil, do desenvolvimento das técnicas de cultivo celular e do descobrimento de um grande número de enterovírus durante os anos 1950 e 1960; nenhum importante agente etiológico de diarréia foi identificado (ESTES e KAPIKIAN, 2007; YOW et al., 1970). Esta situação mudou durante a década de 1970, quando, em 1972 foi feita a primeira descrição da presença de partículas virais associadas a quadros clínicos de diarréias, Kapikian et al., descreveram a descoberta de um agente viral de $27 \mathrm{~nm}$ associado à diarréia em jovens e adultos, por meio de identificação direta do vírus em fezes observadas ao microscópio eletrônico (ME) (KAPIKIAN et al., 1972).

Seguindo esta linha de pesquisa, em 1973, Bishop et al utilizaram a mesma técnica, e identificaram partículas virais de aproximadamente $70 \mathrm{~nm}$ em 
cortes histológicos de mucosa duodenal associadas a um quadro severo de diarréia, em lactentes e crianças pequenas (BISHOP et al., 1973a, 1973b, 1974). Neste mesmo ano, Flewett et al. também identificaram, através de microscopia eletrônica, partículas virais semelhantes a reovírus em amostras de fezes de crianças com diarréia (FLEWETT et al., 1974).

Após estas descobertas, em um curto período de tempo, inúmeros estudos em vários paises relataram a detecção de rotavírus em fezes de crianças com o quadro clinico de diarréia, caracterizando os rotavírus como o principal agente etiológico de diarréia severa, tanto em paises desenvolvidos como em desenvolvimento (BISHOP et al., 1979; ESTES e KAPIKIAN, 2007).

No Brasil, os primeiros relatos da presença de rotavírus foram feitos no final da década de 70 por Linhares et al., (1977) e Candeias et al., (1978). Estes autores descreveram a presença de rotavírus em crianças com diarréia. (LINHARES et al., 1977; CANDEIAS et al., 1978).

Em 1974, a denominação rotavírus foi sugerida pela primeira vez para os anteriormente chamados "reovirus-like" (FLEWETT et al., 1974). Este nome foi proposto devido à semelhança morfológica da partícula viral com uma roda (em latim "rota"), quando observada ao microscópio eletrônico, conforme mostra a figura 1.

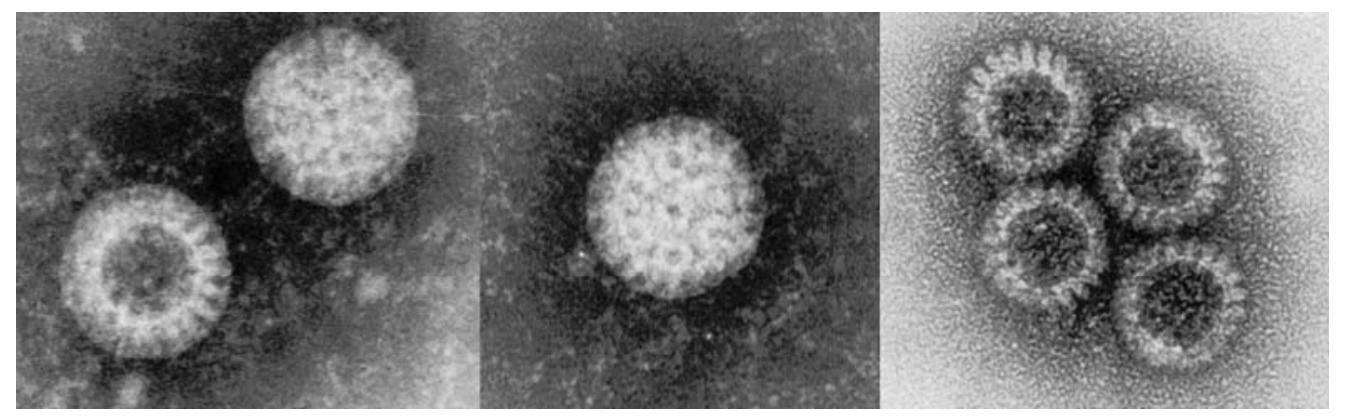

Figura 1: Imagem de partícula de rotavírus observada ao microscópio eletrônico (aumento de 163.600X). Fonte: http://www.ncbi.nlm.nih.gov/ICTVdb/ICTVdB

Em 1976, o Comitê Internacional de Taxonomia dos Vírus (I.C.T.V. International Committe on Taxonomy of Viruses) incluiu pela primeira vez o gênero Rotavirus na família Reoviridae, classificação mantida até hoje. O I.C.T.V. propõe atualmente que os rotavírus sejam divididos em cinco espécies designadas de Rotavirus $A$ até $E$ (RV-A a RV-E), com duas possíveis espécies adicionais (RV-F e RV-G) (FAUQUET et al., 2007). Desta forma, a 
denominação das amostras de rotavírus é feita pela abreviatura da espécie de origem, humana ou animal, da amostra, seguida da espécie de rotavírus à qual ela pertence, e do nome da amostra estabelecido pelo laboratório onde foi isolada. Assim por exemplo, a amostra humana protótipo Hu/Wa é atualmente denominada (HuRV-A/Wa), sendo que Hu refere-se à espécie de origem humana; RV-A refere-se espécie Rotavírus espécie $A$ e Wa ao nome original da amostra (MATTHEWS et al., 1979; FAUQUET et al.,2007).

\subsection{ASPECTOS GERAIS}

Semelhantes a outros membros da família Reoviridae, os rotavírus apresentam uma partícula icosaédrica não envelopada. A partícula íntegra e infectiva dos rotavírus mede aproximadamente $100 \mathrm{~nm}(1000 \AA)$ de diâmetro. $O$ cápside é formado por três camadas protéicas: cápside interno, intermediário e externo com 60 espículas distribuídas na superfície. A integridade do cápside externo é dependente da presença de cálcio. A partícula possui em sua composição as enzimas necessárias à transcrição precoce do vírus (VP1 RNApolimerase RNA dependente e VP3 guanilio tranferase). No interior desta partícula encontra-se o genoma viral composto por 11 segmentos de RNA de fita dupla (dsRNA) (ESTES e KAPIKIAN, 2007).

\subsection{ESTRUTURA}

A estrutura tridimensional dos rotavírus tem sido revelada através de técnicas de criomicroscopia eletrônica (crio-ME), associadas ao uso de programas de computador para o processamento e análise de imagens e, mais recentemente, através do estudo de partículas virais produzidas a partir da expressão gênica de proteínas estruturais em baculovírus (DORMITZER et al., 2004; VENKATARAMAN et al., 2006). A importância destes estudos está na determinação das estruturas moleculares envolvidas nos mecanismos virais de adsorção, penetração, replicação, liberação e neutralização viral, propiciando um melhor entendimento dos aspectos funcionais destas estruturas em processos (PRASAD e CHIU, 1994).

A partícula viral íntegra é formada por três camadas protéicas, o que resulta em três tipos diferentes de partículas, quando os rotavírus são 
observados ao microscópio eletrônico (ME). A partícula completa e infectiva é também denominada de "partícula com tripla camada" (TLPs "tripe-layered particle"). A camada protéica mais externa é denominada de cápside externo (Figura 2A). Quando as TLPs são tratada com agentes quelantes como EDTA (10mM) é possível observar a segunda camada protéica denominada de cápside interno formada por trímeros protéicos da proteína VP6 (figura 2B). A partícula sem a camada externa é denominada "partícula de dupla camada" (DLPs "doble-layered particle") ou partícula rugosa, devido às projeções protéicas do cápside interno. E o terceiro tipo de partícula observada, é denominada de "partícula de camada simples" (SLPs "single-layered particles") também conhecida como "core", freqüentemente observada ao ME à qual o RNA genômico está associado (ESTES e KAPIKIAN, 2007).

Trabalhos recentes propõem que o "core" seja formado pelas proteínas VP1, VP2 e VP3, codificadas respectivamente pelos segmentos 1, 2 e 3 de dsRNA e seja subdividido em duas camadas. As proteínas VP2 formariam uma camada intermediária entre o cápside interno (figura 2b) e o "subcore", este ultimo constituído pelas proteínas VP1 e VP3, associadas ao genoma viral (PRASAD e CHIU, 1994; SHAW et al., 1993).
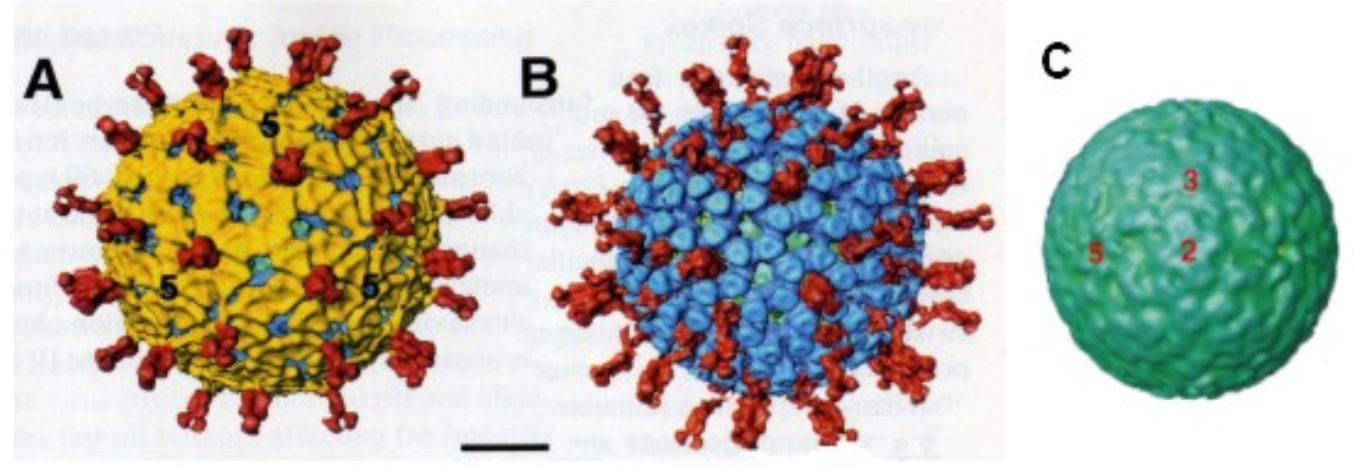

Figura 2: Estrutura tridimensional da partícula de rotavírus. A numeração indica os eixos de simetrias. Adaptado de PRASAD e ESTES, 2000; LAWTON et al., 1997.

O core é composto da proteína VP2 arranjada em 60 dímeros, medindo aproximadamente $51 \mathrm{~nm}$ de diâmetro e $3,5 \mathrm{~nm}$ de espessura com simetria icosaédrica $T=2$ (VENKATARAM et al., 2001). Esta camada envolve o dsRNA genômico que está associado a outras duas proteínas estruturais, VP1(Pol) e a 
VP3 (Cap). Este conjunto é altamente ordenado formando uma estrutura de 12 complexos enzimáticos, ligados à superfície interna da camada de VP2, próximos ao eixo de simetria 5' (PRASAD et al., 1996). A associação do RNA genômico ao complexo enzimático dodecaédrico possui um diâmetro total de 44nm e é denominado "sub-core" (ESTES e KAPIKIAN, 2007).

As duas outras camadas da partícula possuem número de triangulação $T=13$, e são caracterizadas pela presença de 132 canais distribuídos em ambas as camadas protéicas, ligando as camadas externas ao core.

Como é observado na figura 2B, a camada de VP2 (figura 2C) é envolvida pelo cápside interno composto por 780 moléculas de VP6 arranjada em 260 trímeros (Figura 2B). Esta camada forma a parte externa das DLPs e tem aproximadamente $70,5 \mathrm{~nm}$ de diâmetro. A associação da camada de VP6 à camada de VP2 confere à partícula viral maior homogeneidade morfológica e estabilidade por longo prazo, o que sugere que a proteína VP6 seja a maior responsável pela integridade da estrutura da partícula de rotavírus (ZENG, 1994). Esta camada é envolvida pelo cápside externo, formado por duas proteínas estruturais, a VP7 (Figura 2A em amarelo) e a VP4 (Figura 2A em vermelho), ambas importantes para a infectividade viral. A glicoproteína VP7 compõe a superfície do cápside externo, semelhante ao cápside interno, e é formado de 780 moléculas protéicas arranjadas em 260 trímeros agrupados em pentâmeros ou hexâmeros, que interagem com o ápice dos trímeros de VP6. A camada de VP7 apresenta um diâmetro de aproximadamente $75 \mathrm{~nm}$. A glicoproteína VP7 é considerada a proteína "major" do cápside externo, codificada pelos segmentos 7,8 ou 9 de dsRNA dependendo de cada amostra de vírus. Além disso, esta proteína contém um dos antígenos indutores de anticorpos neutralizantes (PRASAD e CHIU, 1994).

Ainda no cápside externo são encontradas 60 espículas compostas de dímeros de VP4, distribuídas sobre sua superfície (figura 2A). Estas espículas estão localizadas nas bordas dos canais nas regiões do eixo do pentâmero (PRASAD et al., 1990). Além disso, já se sabe que estas espículas de VP4 medem aproximadamente $20 \mathrm{~nm}$ sendo que $12 \mathrm{~nm}$ projetam-se da superfície do cápside interno, conferindo à partícula viral dos rotavírus um diâmetro total de $100 \mathrm{~nm}$ (FAUQUET et al., 2007). 
Além disso, $8 \mathrm{~nm}$ da espícula se estende para o interior da partícula viral, interagindo com as proteínas VP7, VP6 e possivelmente com a VP2. Sendo assim, as espículas têm grande importância na manutenção da estrutura da camada tripla protéica (DIRMITZER et al., 2004).

Apesar de ser o componente em menor quantidade do cápside externo, a proteína VP4 parece estar associada a muitas funções importantes para o vírus, e tem função semelhante às proteínas de fusão em vírus envelopados, atuando na aglutinação de hemácias e na virulência; está envolvida no processo de entrada do vírus nas células, e também na indução de anticorpos neutralizantes (PRASAD e CHIU, 1994; BOTH et al., 1994).

A proteína VP4 era anteriormente denominada de VP3 e, após a descrição dos produtos protéicos dos genes 3 e 4, esta proteína passou a ser chamada de VP4 uma vez que corresponde ao produto do gene 4 (PRASAD e CHIU, 1994; ESTES e COHEN, 1989; LIU et al., 1988; MASON et al., 1983).

A camada externa do vírus é extremamente lábil, sendo sua estabilidade dependente de cálcio (HOSHINO e KAPIKIAN, 1994). Desta forma, para manter a integridade e infectividade da partícula viral é necessária a presença de íons cálcio (ESTES e COHEN, 1989). Por outro lado, a estrutura da espícula é estabilizada através da clivagem da VP4 por agentes proteolíticos, e sofre alterações irreversíveis de conformação na presença de pHs altos.

O genoma viral é composto de 11 segmentos de dsRNA com pesos moleculares que variam de 663 a 3.302 pares de bases (pb). No total o genoma dos rotavírus corresponde a 18550 pb (FAUQUET et al., 2007). O dsRNA viral não é infectivo sem a presença das proteínas do cápside, isto por que as proteínas estruturais VP1 e VP3 fazem parte do complexo enzimático responsável pela síntese do mRNA. (ESTES e KAPIKIAN, 2007).

Na maioria dos casos, quando amostras de Rotavírus $A$ são submetidas à eletroforese em gel de poliacrilamida EGPA, o genoma apresenta um padrão eletroforético de migração (eletroferótipo) característico, com os 11 segmentos distribuídos em quatro grupos compostos por 4:2:3:1 segmentos de dsRNA (Figura 3). Estes segmentos são numerados de 1 a 11 de acordo como sua migração na EGPA, o primeiro composto de quatro segmentos de alto peso molecular (1 a 4), seguido de 2 segmentos de médio peso molecular (5 e 6 ) e 
um grupo de três segmentos distintos (7 a 9) e finalmente um grupo formado pelos menores segmentos 10 e 11 (Figura 3). Entretanto a ordem de migração pode variar de cepa para cepa, especialmente os segmentos 7, 8 e 9 ou 10 e 11 dos Rotavírus $A$. Adotou-se como base para a numeração o padrão observado para a amostra SiRV-A/SA11. (GOMBOLD e RAMIG, 1994; PEREIRA et al., 1983; LOURENÇO et al., 1981).

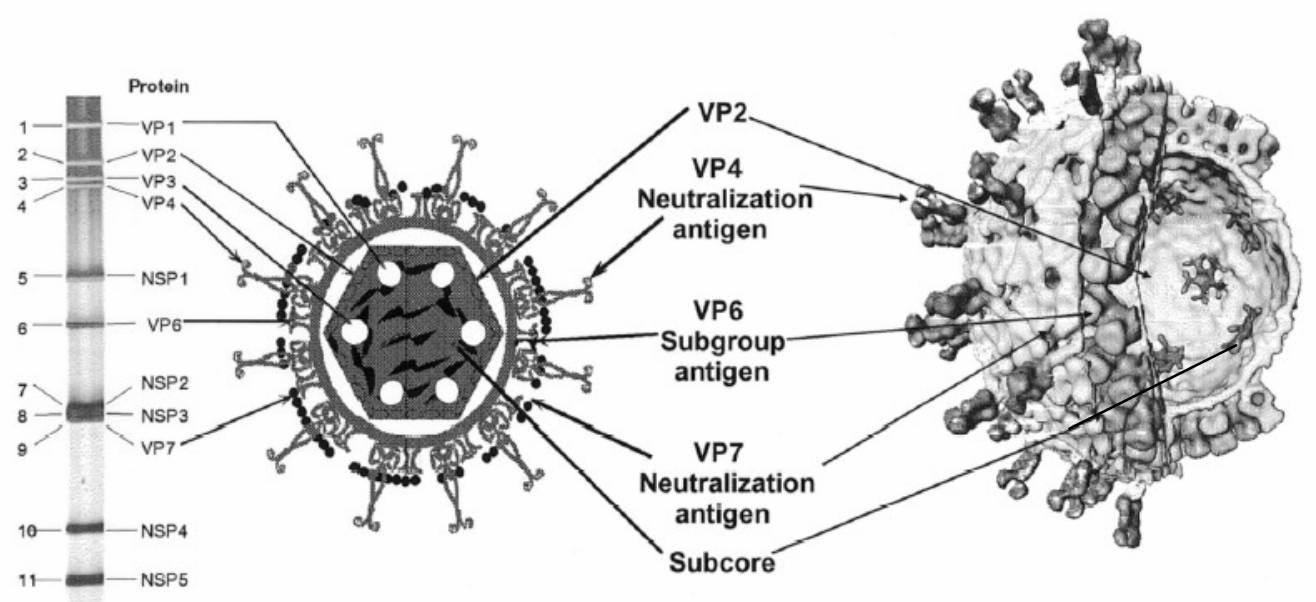

Figura 3: Estrutura da partícula de rotavírus, correspondência entre os segmentos de dsRNA (esquerda), diagrama esquemático (centro) e reprodução do vírus por crio-eletromicroscopia (direita). Localização das proteínas estruturais na partícula de rotavírus do grupo A. NSP, proteína não estrutural. Fonte: de GENTSCH, et al. 2005.

Os rotavírus são os únicos agentes infecciosos conhecidos de vertebrados, com mamíferos e aves, que possuem 11 segmentos de dsRNA o que favorece sua identificação através da técnica de eletroforese em gel de poliacrilamida - EGPA (ESTES et al., 1984; ESTES, 1994). A análise eletroforética do genoma dos rotavírus é relativamente fácil e rápida, sendo uma técnica ainda muito usada para a deteç̧ão e estudos de epidemiologia molecular, sendo útil para monitorar a transmissão em surtos de rotavírus. Diferentes perfis eletroforéticos podem surgir como resultado de mecanismos como shifts, drifts e rearranjos. A identificação de um perfil eletroforético distinto do padrão clássico de 4 grupos (4:2:3:2), pode também ser resultado da análise de amostras de rotavírus aviários de rotavírus não $A$, de um rotavírus $A$ com um rearranjo individual do genoma ou ainda um novo rotavírus A. Contudo a técnica de EGPA não deve ser usada como único critério de 
classificação destas cepas (PEREIRA et al., 1983.; SAIF e JIANG, 1994; ESTES e KAPIKIAN, 2007).

A amostra padrão SiRv-A/SA11 foi a primeira amostra a ter o seu genoma completo seqüenciado. Atualmente várias amostras humanas e animais tiveram as seqüências de nucleotídeos dos 11 segmentos do genoma determinadas. Com base nestas seqüências foi possível estabelecer as características gerais de cada um dos 11 segmentos. O genoma tem se mostrado rico em $A+U$ cerca de $58-67 \%$ do genoma é composto por estes nucleotídeos. Os segmentos possuem um cap na extremidade 5' da fita de polaridade positiva. Além disso, todos os segmentos são pareados de ponta a ponta o que confere a eles uma maior estabilidade.

O esquema dos segmentos de dsRNA dos rotavírus está representado na Figura 4 sendo que cada fita de polaridade positiva inicia-se com uma guanidina na porção 5', seguida de um grupo de seqüências conservadas que corresponde à região 5' não codificadora; Em seguida, observa-se a seqüência codificadora da proteína (ORF - Open Reading Frame), seguida por um código terminador (stop codon). Uma nova região não codificadora na porção terminal é formada por um grupo na região terminal 3', com duas citosinas. Quase todos os mRNA tem uma sua seqüência consenso 5'-UGUGACC-3', que contém um importante sinal para a expressão e replicação gênica (ESTES e KAPIKIAN, 2007).

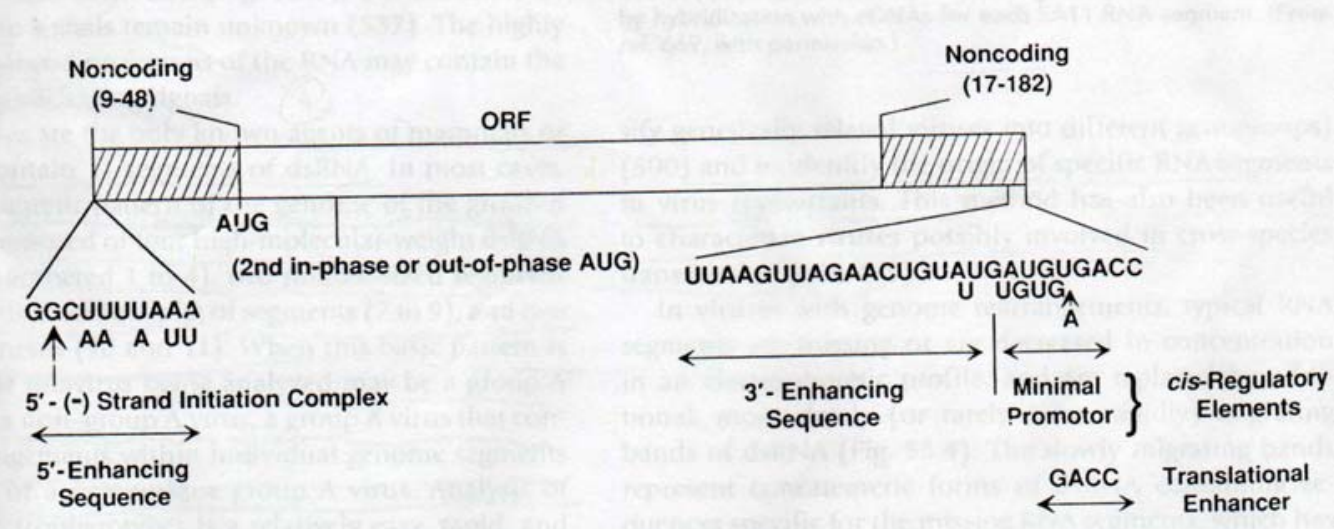

Figura 4: Representação esquemática da estrutura dos genes de rotavírus, segundo publicação das seqüências dos genes 1 a 11. Fonte: ESTES e KAPIKIAN, 2007).

O comprimento total das seqüências não codificadoras 3' e 5' regiões podem variar de gene para gene, mas as seqüências de amostras homólogas 
são altamente conservadas, o que sugere que possuam informações importantes para a replicação, como sinais para transcrição, transporte e empacotamento do RNA e montagem da partícula. Estudos das seqüências das ORFs tem indicado que todos os genes são monocistrônicos, exceto o gene 11 (PATTON et al., 1999). Desta forma, cada segmento de dsRNA codifica pelo menos uma proteína e apenas o gene 11 codifica duas proteínas não estruturais (MATTION et al. 1991; ESTES e KAPIKIAN, 2007). A correspondência entre os segmentos de dsRNA, proteínas virais por eles codificadas e a localização das proteínas estruturais na partícula viral são bem conhecidas (Figura 3), entretanto novas funções destas proteína são descobertas freqüentemente.

A nomenclatura para designação das proteínas virais foi originalmente proposta para as proteínas encontradas na cepa SiRv-A/SA11, quando submetidas à técnica de gel de poliacrilamida com lauril sulfato de sódio (SDSPAGE). As proteínas estruturais são designadas VP (virus protein) seguida da posição desta proteína no gel, sendo 1 a proteína que migra mais lentamente ou a de maior peso molecular (ESTES e KAPIKIAN, 2007). Proteínas originadas da clivagem de um precursor maior são seguidas de um asterisco (ESPEJO et al., 1981; ESTES et al., 1981).

São conhecidas seis proteínas estruturais: VP1, VP2, VP3, VP4, VP6 e VP7, além das proteínas VP5* e VP8* oriundas da clivagem da VP4. Estas proteínas fazem parte da estrutura viral e além disso possuem funções específicas relacionadas à replicação viral. A proteína VP1 é também a enzima polimerase viral, e a VP3 representa as enzimas guanilio transferase e metiltransferase. Estas duas proteínas associadas estão relacionadas à ligação do ssRNA. A proteína VP2 é necessária à atividade de replicase da VP1. A proteína VP4 tem inúmeras funções, como descrito anteriormente, de hemaglutinina, similar a proteínas de fusão, sensível a proteases, participa da ligação vírus célula, está relacionada à virulência e à produção de anticorpos neutralizantes. A proteína VP6 é necessária durante o processo de transcrição e parece estar relacionada ao processo de neutralização intracelular. E finalmente a proteína VP4 está possivelmente relacionada à adsorção do vírus na célula, e suposto sítio de ligação dos íons cálcio. 
Até o momento são conhecidas 6 proteínas não-estruturais, detectadas em células infectadas, que não estão presentes na partícula viral. A nomenclatura adotada para identificar esta proteínas inclui a utilização do prefixo NSP (non-structural protein) seguido do número correspondente à posição desta proteína no gel SDS-PAGE, sendo 1 a proteína que migra mais lentamente. Inicialmente estas proteínas eram identificadas pelo seu peso molecular. Em 1994 Mattion et al. propuseram esta mudança para a numeração sequencial (ESTES e KAPIKIAN, 2007).

A proteína NSP1 com $58 \mathrm{KDa}$, codificada pelo segmento 5 do dsRNA viral, é produzida no início da infecção em baixa concentração. Acredita-se que esta proteína esteja envolvida na replicação do RNA viral associada ao "pré core". A NSP3, com 34,6 KDa, é detectada em larga escala associada ao core durante os últimos estágios da montagem da partícula viral e liga-se 'a extremidade 3' do mRNA viral. A proteína NSP2 com 36,7 kDa é encontrada na partícula sub-viral com atividade de replicase, apresentando propriedades na replicação do RNA e de ligação não específica com o ssRNA. Associa-se à VP1 na formação do viroplasma, sendo então denominada matriz protéica do viroplasma (VIP). Estas duas proteínas (NSP2 e 3) são codificadas por um dos segmentos 7,8 ou 9, dependendo da amostra viral (ESTES e KAPIKIAN, 2007).

A glicoproteína NSP4 com 20,3 kDa é codificada pelo segmento 10 e a glicosilação desta proteína é necessária para a montagem da partícula viral, sendo uma proteína transmembrânica do retículo endoplasmático rugoso (RER), tem papel na morfogênese e recentemente foi descrita como a primeira enterotoxina viral, indispensável à infecção (MATTION et al., 1992; HUANG et al., 2001). As proteínas NSP5 e NSP6 são codificadas pelo segmento 11 e têm pesos moleculares de 21,7 e 12 kDA respectivamente. A NSP5 é uma proteína quinase, fosforilada, com ligação ao RNA e interage com a NSP2 e NSP6, atuando no viroplasma. A NSP6 está presente no viroplasma da maioria das cepas virais interagindo com a NSP5 (ESTES e KAPIKIAN, 2007).

Na Tabela 1 estão relacionadas todas as proteínas virais conhecidas até o momento, o segmento responsável por sua síntese bem como o peso molecular de cada uma destas proteínas e suas respectivas funções. 


\section{Tabela 1. Segmentos genômicos do rotavírus, as proteínas por eles codificadas e suas funções.}

\begin{tabular}{|c|c|c|c|c|c|c|}
\hline $\begin{array}{l}\text { Segmento } \\
\text { Genômico }\end{array}$ & $\begin{array}{c}\text { Tamanho do } \\
\text { segmento em } \\
\mathrm{pb}\end{array}$ & $\begin{array}{l}\text { Nomenclatura } \\
\text { da proteína }\end{array}$ & $\begin{array}{l}\text { Peso molecular da } \\
\text { proteína ( } n^{\circ} \text { de aa) }\end{array}$ & $\begin{array}{c}\text { Localização } \\
\text { da proteína } \\
\text { na partícula viral }\end{array}$ & $\begin{array}{c}\text { No de cópias } \\
\text { por partícula } \\
\text { viral } \\
\end{array}$ & Função \\
\hline 1 & 3302 & VP1 (Pol) & 125,005 (1088) & Core & $<25$ & $\begin{array}{l}\text { RNA polimerase } \\
\text { RNA-dependente }\end{array}$ \\
\hline 2 & 2690 & VP2 (T2) & $102,431(880)$ & Core & 120 & Ligação do RNA \\
\hline 3 & 2591 & VP3 (Cap) & $98,120(835)$ & Core & $<25$ & Guaniltransferase \\
\hline 4 & 2362 & $\begin{array}{l}\text { VP4 } \\
\text { VP5* } \\
\text { VP8* }\end{array}$ & $\begin{array}{l}86,782(776) \\
60,000(529) \\
28,000(247)\end{array}$ & Cápside externo & 120 & $\begin{array}{l}\text { Espícula de superfície, } \\
\text { Antígeno de neutralização (tipos P) } \\
\text { Proteína de adsorção envolvida na } \\
\text { virulência; sua clivagem por tripsina } \\
\text { em VP5* e VP8* aumenta a } \\
\text { infectividade. }\end{array}$ \\
\hline 5 & 1611 & NSP1 & $58,654(495)$ & não estrutural & 0 & $\begin{array}{l}\text { Mais alta diversidade intraespécie, } \\
\text { região rica em Cisteína (zinc finger) } \\
\text { próxima ao residuo aminoterminal. } \\
\text { Componente do pré core. }\end{array}$ \\
\hline 6 & 1356 & VP6 (T3) & 44,816 (397) & Cápside interna & 780 & $\begin{array}{l}\text { Proteína Major,hidrofóbica compõe } \\
\text { camada intermediaria em forma } \\
\text { de unidades trimericas. } \\
\text { Determinantes antigênicos de } \\
\text { grupo e subgrupo. }\end{array}$ \\
\hline 7 & 1104 & NSP3 & $34,600(315)$ & não estrutural & 0 & $\begin{array}{l}\text { Associada ao citoesqueleto, } \\
\text { une-se especificamente à região } \\
\text { 3'dos RNAm dos rotavírus. }\end{array}$ \\
\hline 8 & 1059 & NSP2 (VIP) & $36,700(317)$ & não estrutural & 0 & $\begin{array}{l}\text { Possível papel na replicação do } \\
\text { RNA. Forma multímeros associados } \\
\text { com VP1, envolvidos na formação } \\
\text { do viroplasma. Mostra ligação não } \\
\text { especifica ao ssRNA. }\end{array}$ \\
\hline 9 & 1062 & $\begin{array}{c}\text { VP7 (1) } \\
\text { VP7 (2) } \\
\text { forma clivada } \\
\text { madura }\end{array}$ & $\begin{array}{c}37,368(326) \\
33,919(297) \\
276\end{array}$ & cápside externa & 780 & $\begin{array}{l}\text { Gene bicistrônico,alta glicolsilação } \\
\text { Glicoproteína da membrana do } \\
\text { RER, possível proteína de adsorção, } \\
\text { antígeno de neutralização (tipos G), } \\
\text { sítio putativo de ligação de Ca++. }\end{array}$ \\
\hline 10 & 751 & NSP4 & $20,290(175)$ & não estrutural & 0 & $\begin{array}{l}\text { Glicoproteína trans- membrana do } \\
\text { RER, papel na morfogênese, duas } \\
\text { regiões hidrofóbicas na região amino } \\
\text { terminal, enterotoxina } \\
\text { sitio putativo de ligação de Ca++ }\end{array}$ \\
\hline 11 & 667 & $\begin{array}{l}\text { NSP5 } \\
\text { NSP6 }\end{array}$ & $\begin{array}{c}21,725(198) \\
11,012(92)\end{array}$ & não estrutural & $\begin{array}{l}0 \\
0\end{array}$ & $\begin{array}{l}\text { Fosforilada, rica em serina e } \\
\text { treonina, ligação ao RNA, a quinase } \\
\text { Interage com a NSP6, produto da } \\
\text { 2a. região aberta de leitura } \\
\text { Presente nos corpúsculos de } \\
\text { inclusão viral }\end{array}$ \\
\hline
\end{tabular}

Fonte ESTES, 2001; VAN-REGENMORTEL, 2000. 


\section{4 REPLICAÇÃO}

Os estudos da replicação dos rotavírus foram primeiramente realizados em linhagens continuas de células de rim de macaco (MA-104) e ME. Atualmente a utilização de células de epitélio intestinais polarizadas, associada ao uso de microscopia confocal, permite o estudo das interações específicas das proteínas e do ácido nucléico, através do uso de sondas específicas para cada etapa da replicação viral. Estes avanços permitiram a elucidação completa de várias etapas da replicação dos rotavírus (ESTES e, KAPIKIAN, 2007).

Os principais estágios da replicação viral estão representados na Figura 5 e são descritos a seguir, seguindo a respectiva numeração indicada entre parênteses e em algarismos romanos, após a descrição de cada evento.

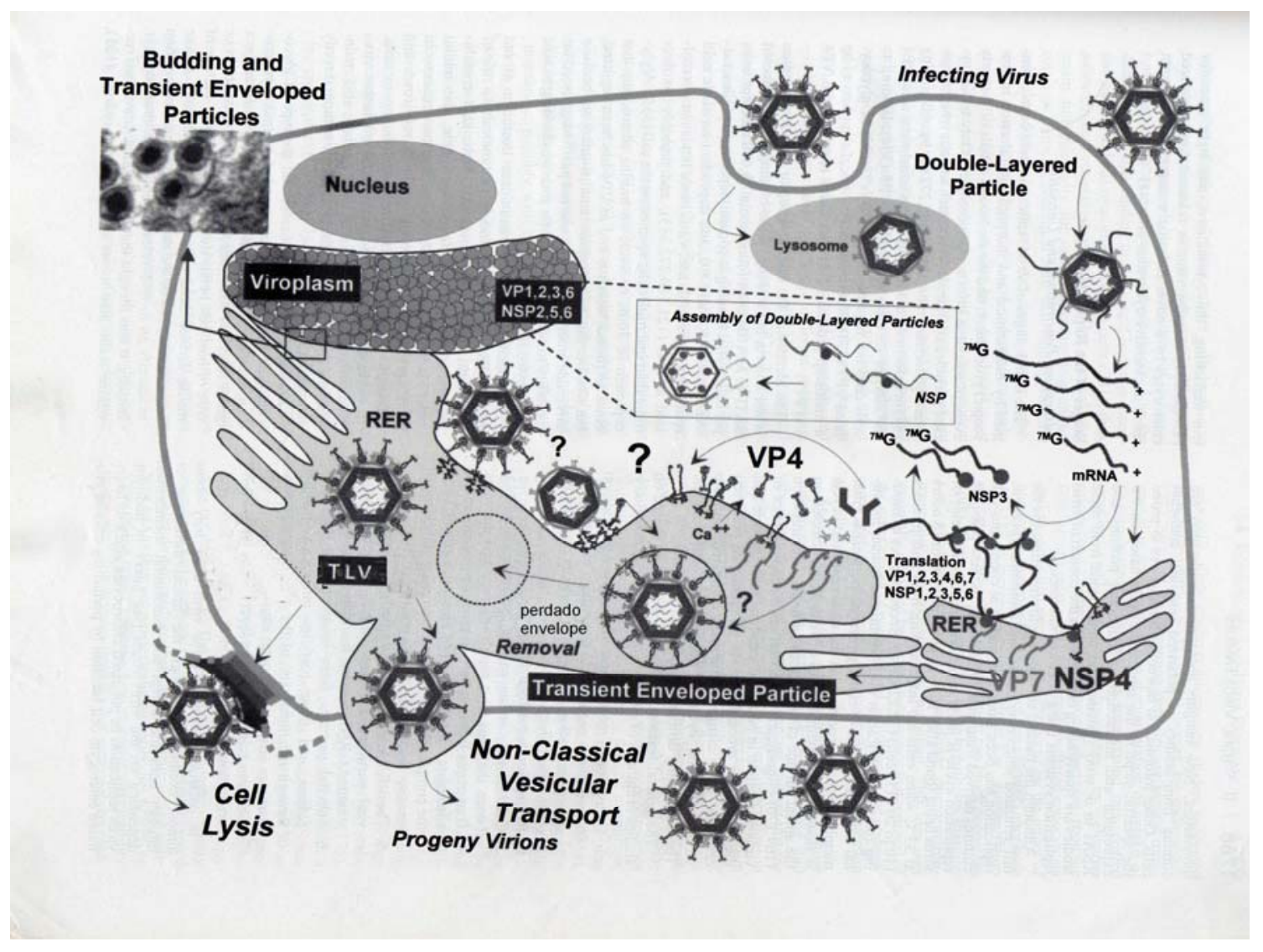

Figura 5: Esquema da replicação dos rotavírus. Fonte: ESTES, 2001.

Os estudos revelaram que a adsorção da partícula viral completa é afetada por variações de $\mathrm{pH}$ e de temperatura. A ligação ocorre entre os anti- 
receptores virais presentes no cápside externo, formados pelas espículas de VP4 e os receptores celulares presentes na membrana plasmática (I). Em células animais, a ligação vírus célula se dá através dos resíduos de ácido siálico, presentes na superfície da membrana plasmática. A observação do processo de adsorção em células polarizadas indicou dois locais distintos onde as partículas virais costumam se ligar, na região apical onde a ligação se dá com resíduos de ácido siálico e a região basolateral onde a ligação se dá de maneira independente do ácido siálico. Isto indica a existência de mais de um receptor de membrana envolvido na ligação vírus-célula. Além disso, participa da adsorção uma forma glicosilada da proteína VP7 e a proteína VP5*. Sabese também que esta ligação inicial vírus célula é sódio-dependente.

Estudos demonstram que a penetração da partícula viral na célula hospedeira pode ser direta através da membrana celular e por endocitose mediada por receptores celulares. A penetração direta (Ila) ocorre "in vivo" (ROSETO et. al., 1981) como resultado da alteração da permeabilidade da MP, após a clivagem da VP4, na presença enzimas proteolíticas. Acredita-se que esta clivagem ocorra dentro do intestino delgado pela ação de proteases pancreáticas (GRAHAM e ESTES, 1980; BASS et. al., 1992). Quando a penetração se dá por endocitose (Illb), ou seja, sem a ação de enzimas proteolíticas, a partícula permanece dentro de um lisossomo e é posteriormente degradada no interior da célula. Este fato tem sugerido que a infecção produtiva ocorra somente através da entrada do vírus por penetração direta, através da membrana celular (VENKATARAM et al., 2001; ESTES, 2001).

Após a internalização do vírus, o cápside externo é perdido, e a DLP ativa é liberada no citoplasma da célula infectada e tem suas enzimas transcricionais ativadas (III) (JAYARAM et al., 2004). Como as células hospedeiras não contém as enzimas necessárias para a replicação do dsRNA, a DLP se mantêm íntegra estruturalmente durante o processo de replicação, possuindo todas as enzimas necessárias à transcrição, que ocorre por ação da RNA-polimerase-RNA-dependente (VP1) e do complexo enzimático de VP1 + VP3 . Os mRNA transcritos agem tanto na produção de proteínas quanto como molde para a produção da fita negativa complementar, que permanece associada à fita positiva, dando origem ao genoma da progênie viral. A síntese 
do dsRNA parece atingir seu pico máximo entre 9 a 12 horas após a infecção. (SILVESTRI et al., 2004; ESTES e KAPIKIAN, 2007).

Alguns aspectos importantes na replicação do ácido nucléico dos rotavírus são: (a) O mRNA é o único ácido nucléico viral encontrado livre no citoplasma da célula infectada, e portanto as interações genéticas ocorrem no nível do mRNA. (b) $O$ dsRNA genômico e da progênie estão sempre associados à partícula viral, nunca o dsRNA é encontrado livre. (c) Todas as atividades de polimerase, transcriptase ou replicase estão também associadas à partícula viral (PATTON et al., 2004).

Estudos sobre a síntese das proteínas virais revelam que, quatro horas após a infecção, a síntese de polipeptídios celulares encontra-se fortemente inibida, e é substituída pela síntese de proteínas virais. O processo através do qual os onze segmentos de dsRNA são encapsidados dentro de cada virion ainda não está bem esclarecido. Entretanto, parece ser provável que pelo menos as proteínas não estruturais NSP1, NSP2, NSP3 e NSP4 estejam envolvidas neste processo (TARAPOREWALA e PATTON, 2004; PATTON e SPENCER, 2000).

A montagem das partículas de DLP está associada à formação de viroplasmas. No interior do RER as DLP brotam através da membrana do RER adquirindo a camada TLP. Durante esse processo, ocorrem interações específicas entre as proteínas estruturais (VP4, VP7 e VP6) e a NSP4 e as partículas virais apresentam-se transitoriamente envelopadas. Não está claro se a montagem de VP4 ocorre antes ou após o brotamento. A partícula viral completa perde o seu envelope durante os estágios finais de maturação, migra para o citoplasma e os virions são liberados através de lise celular na luz do intestino (GONZALEZ et al., 2000; BERKOVA et al., 2006). As diferenças de concentração de $\mathrm{Ca}^{2+}$ intracelular parecem ter papel determinante para a maturação do vírus, e posterior morte celular (PEREZ et al., 1999; BERKOVA et al., 2006).

A replicação dos rotavírus ocorre nos enterócitos (células epiteliais) maduros do topo das vilosidades. A severidade e o local da infecção por rotavírus parece variar de acordo com a espécie animal, ocorrendo na maioria das vezes nos limites do intestino delgado, sendo o jejuno o principal local da 
infecção. Entretanto, trabalhos recentes têm demonstrado a ocorrência de replicação viral em outras regiões (CRAWFORD et al., 2006; FENAUX, et al. 2006).

\section{5 CLASSIFICAÇÃO SOROLÓGICA}

Do ponto de vista sorológico e molecular, os rotavírus são classificados em grupos (sorogrupos), que apresentam subdivisões em subgrupos e sorotipos/genótipos.

Até o momento são conhecidos sete grupos sorológicos distintos de rotavírus denominados de $A$ até $\mathrm{G}$, caracterizados em função de diferenças em determinantes antigênicos, localizados na proteína VP6. Em um mesmo sorogrupo são incluídas amostras que apresentam reação sorológica cruzada, quando avalizada por alguma técnica sorológica como imunofluorescência, ensaio imunoenzimático (ELISA) ou imunomicroscopia eletrônica (IME). (ESTES e KAPIKIAN, 2007).

Os rotavírus dos grupos A, B e C são encontrados tanto em humanos, como em animais, enquanto que os rotavírus dos grupos $D, E, F$ e $G$ têm sido descritos apenas em animais.

Em humanos, os rotavírus do grupo $B$ e $C$ são freqüentemente associados à epidemias em adultos e crianças (YEE et al., 2006, SANCHEZFAUQUIER, et al. 2003). Os primeiros casos ocorreram na China e no Japão nos anos 80 (SAIF e JIANG,1994), e mais recentemente, em outros países (PHAN et al., 2004; STEYER et al., 2006; RAHMAN, 2005; SCHNAGL et al., 2004), sugerindo que estes vírus sejam patógenos emergentes para o homem. O diagnóstico dos rotavírus dos grupos não-A tem sido feito através de microscopia eletrônica, eletroforese em gel de poliacrilamida e, para rotavírus do grupo B e C, através de ensaio imunoenzimático (NAKATA et al., 1986; YOLKEN et al., 1988; GATTI et al., 1989). Além disso, técnicas moleculares têm sido aplicadas para ampliar o conhecimento sobre as proteínas destes grupos (SCHNAGL et al., 2004; CHEN et al., 2002; AHMED et al., 2004; JIANG et al., 2005; BARMAN et al., 2006).

Os rotavírus do grupo A são também classificados em subgrupos e sorotipos/genótipos G e P. Na classificação dos rotavírus do grupo A em 
subgrupos, são utilizados determinantes antigênicos localizados também na proteína VP6, detectados por ensaio imunoenzimático ou hemaglutinação por imunoaderência (ESTES e KAPIKIAN, 2007). São conhecidos dois subgrupos distintos, designados pelos algarismos romanos I e II (FAUQUET et al., 2007). Em humanos são identificadas mais freqüentemente amostras dos subgrupos I ou II. Trabalhos com rotavírus animais têm identificado amostras de origem eqüina com especificidade para ambos os subgrupos I e II, (HOSHINO et al., 1987) e outras amostras de origem eqüina, bovina ou aviária sem especificidade para ambos os subgrupos, que são denominadas subgrupo nãoI não-II (HOSHIRO e KAPIKIAN, 1994; LIPRANDI et al., 1990.), o que sugere a possível existência de novos subgrupos.

Para a classificação dos rotavírus do grupo $A$ em sorotipos, são considerados dois determinantes antigênicos distintos, localizados nas duas proteínas do cápside externo, a VP7 e a VP4. A primeira, a glicoproteína VP7, constitui o determinante primário da especificidade de sorotipo, determinando os sorotipos/genótipos $\mathrm{G}$, assim denominados por estarem relacionados à glicoproteína (ESTES e KAPIKIAN, 2007). Esta, dependendo da amostra, é codificada pelos segmentos genômicos 7, 8 ou 9. A proteína VP4, que é a segunda proteína que compõe o cápside externo, determina os sorotipos $P$, assim denominados devido à sensibilidade desta proteína às proteases (ESTES e KAPIKIAN, 2007). A determinação de sorotipo pode ser feita por técnicas sorológicas como ensaios imunoenzimático utilizando-se anticorpos monoclonais (NAKAGOMl et al., 1989; TANIGUCHI et al., 1987) inibição de focos fluorescentes com soros policlonais monovalentes (NAKAGOMI et al., 1989), absorvidos para os demais sorotipos ou através da reação de neutralização. Além destas técnicas, também têm sido usadas para a caracterização dos rotavírus técnicas moleculares para determinar os genótipos $\mathrm{G}$ e $\mathrm{P}$ de amostras de rotavírus. Neste caso, é feita a comparação da seqüência de aminoácidos ou nucleotídeos das proteínas VP7 ou VP4 e, quando existe uma homologia igual ou maior a $89 \%$, as amostras são consideradas do mesmo genótipo (GOUVEIA et al., 1990; GENTSCH et al., 1992; NAKAGOMI et al., 1993; PARWANI et al., 1993; DAS et al., 1994). 
Atualmente são conhecidos 15 sorotipos/genótipos $\mathrm{G}$ de rotavírus designados de G1 a G15 (FAUQUET et al., 2007). Em humanos, os sorotipos G1 a G4 são encontrados com maior freqüência. Além destes já foram descritas amostras dos genótipos G5, G6, G8, G9, G10, G11 e G12. Todos os 15 sorotipos/genótipos $\mathrm{G}$ foram observados em animais TABELA 2 (ESTES e KAPIKIAN, 2007).

Quanto à diferenciação sorológica e molecular baseada na proteína VP4, existem duas classificações distintas em uso na literatura: os genótipos $\mathrm{P}$ e os sorotipos P. Como descrito acima, estas duas classificações são conseqüência do método de análise das proteínas das amostras virais. Entretanto, no caso da proteína VP4, não existe ainda uma correspondência entre os resultados obtidos na sorotipagem, e os obtidos na genotipagem. Como é possível observar na Tabela 3, são hoje estabelecidos 27 genótipos (MARTELLA et al., 2007) e 15 sorotipos $\mathrm{P}$ de rotavírus (ESTES e KAPIKIAN, 2007). Com relação aos tipos $P$ recomenda-se que a designação completa do sorotipo e genótipo $P$ deva ser feita utilizando-se numeração simples para indicar o sorotipo, seguido de numeração entre colchetes para indicar o genótipo (p.ex. amostra padrão HuRV-A/WA é designada P1A[8] (ESTES, 2001). 
Tabela 2: Classificação de sorotipos e genótipos $G$ de rotavírus do grupo $A$. Cepas e espécies onde estas amostras foram identificadas. Fonte: ESTES e KAPIKIAN, 2007.

\begin{tabular}{|c|c|c|}
\hline \multirow{2}{*}{$\begin{array}{l}\text { Sorotipol } \\
\text { Genotipo } \\
\end{array}$} & \multicolumn{2}{|c|}{ Espécie de origem seguida danome da amostra } \\
\hline & Humanos & Animais \\
\hline 1 & $\begin{array}{l}\text { Wa, KU, RV-4, K8, D, M37, Mont, AU64, W179, AU19. } \\
\text { AU32, HN-1, GR475/87, 89-12, GR67/91 }\end{array}$ & $\begin{array}{l}\text { Bo/7449, } \mathrm{ro} / \mathrm{C} 60, \mathrm{Po} / \mathrm{C} 91, \mathrm{Po} / \mathrm{C} 95, \mathrm{Fo} / \mathrm{CN} 117, \mathrm{Po} / \mathrm{CBS} \\
\mathrm{Po} / \mathrm{S7}, \mathrm{Po} / \mathrm{S8A}\end{array}$ \\
\hline 2 & $\begin{array}{l}\text { DS-1, SC2, S2, RV-5, RV-6, KUN, HN-126, 1076, E201, } \\
\text { E210, HUS, 7PE/89, BS3585/99, TB-Chen, TA3, TA20 }\end{array}$ & $\mathrm{Po} / 34461.4^{\circ}$ \\
\hline 3 & $\begin{array}{l}\text { Ito, YO, P, M, Nemoto, AU-1, RV-3, W178, AK-35, ST8, } \\
\text { MO, McN13, McN14, HCR33, CH927A, Ro } 1845 \text {, } \\
\text { O264, AU228, PA710, 02/92, CH-32, CHW2, CHW17, } \\
\text { CH-55, Al-75, J-12, TKO8, TK28, 107E18, 157C, B4106 }\end{array}$ & 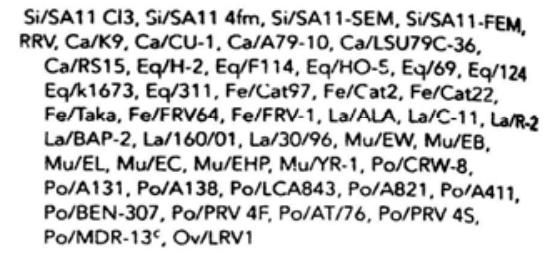 \\
\hline 4 & Hochi, Hosokawa, ST3, 57M, BrB, ST4, VA70 & $\begin{array}{l}\text { Po/Gottfried, Po/SB-1A, Po/SB-2A, Po/BEN-144. } \\
\text { Po/BMl-1 }\end{array}$ \\
\hline 5 & BR1054, IAL28' & $\begin{array}{l}\mathrm{Po} / \mathrm{OSU}, \mathrm{Po} / \mathrm{EE}, \mathrm{Po} / \mathrm{TFR}-41, \mathrm{PO} / \mathrm{A} 34, \mathrm{PO} / \mathrm{A} 46, \mathrm{Po} / \mathrm{C} 134, \\
\mathrm{Po} / \mathrm{CC} 117 . \mathrm{Po} / \mathrm{SBB}, \mathrm{Po} / 134 / 04-15, \mathrm{E} / \mathrm{H}-1\end{array}$ \\
\hline 6 & PA151, PA169, MG6, Hun4, Hun5, ASG6.02 & 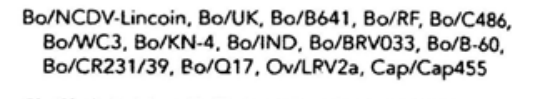 \\
\hline 7 & & $\mathrm{Ch} / \mathrm{Ch}-2, \mathrm{~T}_{y} / \mathrm{Ty}_{\mathrm{y}} 1, \mathrm{~T}_{\mathrm{y}} / \mathrm{T}_{\mathrm{y}}-3, \mathrm{P} / \mathrm{PO} \mathrm{P}-13, \mathrm{Bo} / 993 / 83$ \\
\hline 8 & $\begin{array}{l}\text { 69M. B37, HAL1166, HAL 1271, HAL8590, EGY2295, } \\
\text { GRVS70. DG8. OEH14262, HMG89. MW333, } \\
\text { MW023, EGY1850 }\end{array}$ & $\begin{array}{l}\text { Bo/678, Bo/AS, BN/NCDV-Cody, Bo/J2538, Bo/BRV16, } \\
\text { Bo/Sun9, Bo/Niigata, Eq/26/94, Ov/OVR762, LURio } \\
\text { Negro, L/Chubut }\end{array}$ \\
\hline 9 & W161, F45, Mc523, AU32, US1205, Mc345, 116E, Mc323 & Po/ISU-64, Po/S5, Po/A2, Po/S8 Ov/LRV2c \\
\hline 10 & 1321. Mc35 A28. A64 & $\begin{array}{l}\text { Bo/B223, Bo/61A, Bo/N1005, Bo/KK3, Bo/B-11, Bo/A4, } \\
\text { Bo/CR129, Bo/BR65/225, Eq/R-22, OV /LP14, OV/K923 } \\
\text { Po/P343 }\end{array}$ \\
\hline 11 & Dhaka6 & Po/MM, Pc/A253 \\
\hline 12 & $\begin{array}{l}\text { L20, L27, US585, T152, Se585, K12, isO-1, ISO-2, } \\
\text { ISO-5, CP727, CP1030, }\end{array}$ & Po/RU1\%2 \\
\hline 13 & & Eq/L338 \\
\hline 14 & & $\mathrm{Eq} / \mathrm{F} 123, \mathrm{Eq} / \mathrm{FR} 4, \mathrm{Eq} / \mathrm{FR} 5, \mathrm{Eq} / \mathrm{FR} 8, \mathrm{Eq} / \mathrm{EO} 431, \mathrm{Eq} / \mathrm{CH} 3$ \\
\hline 15 & & Bo/Hg18 \\
\hline
\end{tabular}


Tabela 3: Classificação de sorotipos e genótipos $P$ de rotavírus do grupo $A$. Cepas e espécies onde estas amostras foram identificadas. Fonte: ESTES e KAPIKIAN, 2007; MARTELLA et al., 2007.

\begin{tabular}{|c|c|c|c|}
\hline \multirow[b]{2}{*}{ Genotipo } & \multirow[b]{2}{*}{ Sorotipos } & \multicolumn{2}{|c|}{ Espécie de origem seguida danome da amostra } \\
\hline & & Humano & Animal \\
\hline 7 & 6 & & $\begin{array}{l}\text { Bo/C486, Bo/NCDV, Bo/BRVO33, BoBPV16, Bo/A5, } \\
\text { Ro/CR231/39, Bo/J2536, Bo/RF, Si/SA11 4fm, } \\
\text { Si/SA11-FEM, Eq/26/94, OV/LRV1 }\end{array}$ \\
\hline 2 & $5 B$ & & Si/SA11, C13, Si/SA11-SEM \\
\hline 3 & 58 & & $\mathrm{Si} / \mathrm{RRV}, \mathrm{Fe} / \mathrm{FRV} 64 ; \mathrm{Bu} / 10733 ; \mathrm{Ca} / \mathrm{GRV}$ \\
\hline & 5A & Ro1845, HCR3a & $\mathrm{Ca} / \mathrm{Ka}, \mathrm{Ca} / \mathrm{CU}-1, \mathrm{Ca} / \mathrm{RS} 15, \mathrm{Fe} / \mathrm{Cat} 97$ \\
\hline 4 & 18 & $\begin{array}{l}\text { RV-5, DS-1, S2, L26, KUN,E210, E201, } \\
\text { CHW17, AU64, 107E18, MW333, TB.Chen }\end{array}$ & \\
\hline 5 & 7 & A6Gi & $\begin{array}{l}\text { Bo/UK, Bo/WC3, Bo/B64i1, Bo/t1A, Bo/NMR', } \\
\text { Bo/678, BoN/1005, Bo/iND, Po/PRV 4S, Po/343 }\end{array}$ \\
\hline 6 & $2 \mathrm{~A}$ & $\begin{array}{l}\text { M37, 1076, RV-3, ST3, SC2, BrB } \\
\text { McN13, US1205, MWO23, US585 }\end{array}$ & Po/134-04-8, Po/134/4-10 \\
\hline & $\begin{array}{l}2 \mathrm{~B} \\
2 \mathrm{C}\end{array}$ & 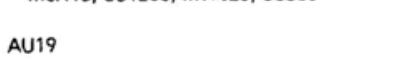 & $\begin{array}{l}\text { Po/Gottfried, Po/BEN-144, Po/S5, Po/S7, Po/SB-2A } \\
\text { Po/JP3-6, Po/JP29-6 }\end{array}$ \\
\hline 7 & 9 & AUIY & 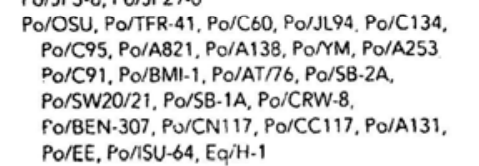 \\
\hline 8 & $1 \mathrm{~A}$ & $\begin{array}{l}\text { Wa, Ku, P, YO, MO, VA70, D, AU32, CH-32, } \\
\text { CH-55. CHW2, CH927A, W161, F45, Ai-75, } \\
\text { Hochi, Hosokawa, BR1054, WI78, W79 }\end{array}$ & $\mathrm{PO} / \mathrm{SBA}, \mathrm{PO} / \mathrm{SBB}, \mathrm{OV} / \mathrm{LVVZC}$ \\
\hline 9 & 3 & $\begin{array}{l}\text { K8, AU-1, PA151, M318, AU228, 02/92, } \\
\text { T152, O264 }\end{array}$ & $\mathrm{Fe} / \mathrm{FRV}-1, \mathrm{Fe} / \mathrm{Cat} 2$ \\
\hline 10 & 4 & $69 \mathrm{M}, 57 \mathrm{M}, 837$ & \\
\hline 11 & 8 & $116 E, 1321,157 \mathrm{C}$ & $\begin{array}{l}\text { Bo/B223, Bo/A44, Bo/KK3, Bo/B-11, Bo/Cr, } \\
\text { Bo/KN-4, Bo/CR129, Bo/BR65/25S, Eq/R-22, } \\
\text { Ov/LRV2a }\end{array}$ \\
\hline 12 & 4 & & $\begin{array}{l}\text { Eq/H-2, Eq/F114, Eq/F123, Eq/FR4, Eq/FR5, } \\
\text { Eq/FP8. Eq/K311, Eq,'K1673, Eq/CH3, Eq/69. } \\
\text { Eq/124, Eq/EO431 }\end{array}$ \\
\hline 13 & & & Po/MDR-13, Po/A46, Po/Clon8 \\
\hline 14 & 11 & $\begin{array}{l}\text { PA169, HAL1166, HAL1271, HAL8590, } \\
\text { Mc35, MG6, GR475/87, 84106 }\end{array}$ & $\begin{array}{l}\text { Cap/Cap455 } \\
\text { La/MV1, La/MV3, L/Rio Negru, L/Chubut } \\
\text { Ov/OVR762 }\end{array}$ \\
\hline 15 & Not tested & & Ov/Lp14, Ov/Lp16, Ov/K923 \\
\hline 16 & 10 & & Mu/EBB, Mu/EW, Mu/EC \\
\hline 17 & Not tested & & $\mathrm{Pi} / \mathrm{PO}-13, \mathrm{BO} / 993 / 83, \mathrm{Ch} / \mathrm{Ch}-1, \mathrm{~T}_{y} / \pi_{\mathrm{y}-1}, \mathrm{~T}_{\mathrm{y}} / \mathrm{T}_{\mathrm{y}-3}$ \\
\hline $\begin{array}{l}18 \\
19\end{array}$ & Not tested & & Eq/L338 \\
\hline 19 & 12 & Mc323, Me345 & PO/PRV AF \\
\hline 20 & 13 & & MU/EHP \\
\hline 21 & Not tested & & Bo/Hg18 \\
\hline 22 & Not tested & & $\begin{array}{l}\mathrm{La} / 160 / / 11, \mathrm{La} / 229 / 01, \mathrm{La} / 308 / 01, \mathrm{La} / \mathrm{MV} 2, \mathrm{La} / \mathrm{Mv} 4 \text {, } \\
\mathrm{La} / \mathrm{MVS}\end{array}$ \\
\hline 23 & 14 & & Po/A34, Po/34461-4 \\
\hline 24 & Not tested & & $\mathrm{Si} / \mathrm{TUCH}$ \\
\hline 25 & Not tested & Dhakab & \\
\hline $\begin{array}{l}26 \\
27\end{array}$ & Not tested & & $\mathrm{Po} / 134 / 04.15$ \\
\hline 27 & & & Po/344-04-1* \\
\hline
\end{tabular}




\section{6 PATOGENESE}

A infecção por rotavírus pode ser assintomática ou produzir sintomas que variam da diarréia branda à severa, com desidratação que pode levar à morte (ESTES e KAPIKIAN, 2007). É importante lembrar que a patogênese das infecções por rotavírus tem sido revelada através de estudos utilizando modelos animais e vírus do grupo A. A ocorrência de sintomas e sua gravidade estão relacionadas com a idade, o estado nutricional, imunidade do hospedeiro, bem como com o potencial de patogenicidade da cepa viral (LINHARES e BRESSE, 2000; BURKE e DESSELBERGER, 1996).

As manifestações clínicas mais comumente observadas são diarréia, vômito, febre, desidratação e dor abdominal. A diarréia dura em média de 5 a 8 dias (OFFIT, 1996). Um efeito colateral grave é a ocorrência intussuscepção intestinal, uma condição na qual uma porção do intestino invagina em outra porção produzindo obstrução intestinal (NAKAGOMI, 2000). Além disso, estudos em modelos animais demonstraram que a infecção do pâncreas pelos rotavírus pode originar um quadro de diabetes tipo 1, que seria o resultado de um processo auto-imune (COULSON et al., 2002).

Ramig (2004) em seu trabalho de revisão sobre patogenia das infecções por rotavírus sugere que este processo deva ser considerado como um evento envolve múltiplos fatores, apresentando componentes relacionados à partícula viral e ao hospedeiro, bem como fatores relacionados ao próprio processo diarréico. Todos estes fatores devem ser considerados para seu completo entendimento. De um modo geral, estes fatores possuem como componentes a má absorção, resultante dos danos iniciais causados pela infeç̧ão viral ao epitélio intestinal, fatores relacionados à síntese e ação da NSP4 e efeitos relacionados ao sistema nervoso entérico que sofre a ação dos processos envolvidos na infecção por rotavírus.

A infecção viral é rapidamente lítica para os enterócitos. Em alguns modelos são observadas alterações microscópicas, que incluem encurtamento leve das vilosidades, hipertrofia da cripta, presença de microvilosidades esparsas e irregulares, bem como infiltração mononuclear moderada da lâmina própria, vacuolização celular e até hiperplasia da cripta. Devido à perda das células maduras das vilosidades, a migração das células da cripta é acelerada. 
Estas células que migram das criptas para o topo das vilosidades apresentam deficiência na produção de dissacaridases e na absorção, devido à sua imaturidade.

Este processo altera completamente as funções do epitélio do intestino delgado, o que leva a uma diarréia do tipo osmótica, que inclui a diminuição da absorção de sais e água relacionada à perda da capacidade de absorção, atividade normalmente executado pelos enterócitos maduros. A má-absorção resulta no trânsito e não digestão dos monossacarídeos e dissacarídeos, carboidratos, gorduras e proteínas pelo colon. Alguns trabalhos sugerem que a má absorção e os danos causados ao epitélio sejam resultado não só da infecção das células da cripta, mas também da isquemia das vilosidades (GRAHAM e ESTES, 1991).

Outro fator importante na diarréia causada pela infecção por rotavírus é a presença da proteína NSP4. Esta proteína possui uma atividade semelhante a de enterotoxinas bacterianas, já que ela provavelmente interage na mediação da diarréia, afetando locais do intestino ainda não infectados pelo vírus (RAMIG, 2004).

Os aspectos intracelulares da diarréia por rotavírus parecem estes intimamente relacionados à atividade da NSP4. Esta enzima promove a alteração na membrana do retículo endoplasmático rugoso (RER) levando a saída de íons $\mathrm{Ca}^{2+}$ do interior do RER, o que promove um aumento da concentração destes íons no interior do citoplasma celular, que acarreta a ruptura do citoesqueleto das vilosidades (JOURDAN, et al., 1998). Causa ainda a diminuição da síntese de dissacarídeos, diminuição da síntese de enzimas digestivas pelas células apicais e também a inibição do transporte de $\mathrm{Na}^{+} \mathrm{e}$ outros solutos (MIR et al., 2007). Estes fenômenos contribuem para a redução da capacidade de absorção do epitélio (RAMIG, 2004).

A ação da NSP4 atinge também as células não infectadas. A NSP4 usa receptores celulares relacionados à fosfolipase para entrar nas células vizinhas, promovendo uma ação em cascata que culmina com a queda da concentração de $\mathrm{Ca}^{2+}$ no interior do retículo, e conseqüentes alterações da capacidade celular de absorção. A atuação direta da NSP4 sobre os enterócitos resulta na alteração da permeabilidade celular (RAMIG, 2004). 
Estudos recentes com fármacos que atuam no sistema nervoentérico (ESN) tem demonstrado que existe uma relação entre a diarréia por rotavírus e a produção de fluídos eletrolíticos pelo ESN, mediada também pela presença da NSP4 (GILGER, et al., 1992). A ativação do ENS durante a infecção por rotavírus explicaria também como as células infectadas do topo das vilosidades poderiam estimular a secreção de eletrólitos e água. Outro aspecto importante da diarréia por rotavírus relacionado à ação do ENS é a diminuição do trânsito ou motilidade intestinal (RAMIG, 2004).

Fatores relacionados ao hospedeiro também parecem ser importantes na determinação da intensidade a diarréia durante a infecção por rotavírus. A má nutrição parece ser um fator importante relacionado à severidade das infecções por rotavírus, causando um retardo na recuperação das células intestinais e também acarretando uma resposta inflamatória diferente. Além disso, aparentemente, a ocorrência mais freqüente de infecções entre lactentes e crianças na primeira infância não está associada à presença ou não de receptores celulares para os rotavírus ou a NSP4, já que estes são encontrados tanto em animais adultos como em neonatos, apesar de ser observada uma forte queda na presença destes receptores com o aumento da idade. A idade parece estar principalmente associada à produção de anticorpos neutralizantes (BURKE e DESSELBERGER, 1996).

Outro fator importante para a infecção por rotavírus e também a idade parecem estar relacionado aos níveis de produção de proteases que são necessárias à clivagem da proteína VP4. Em recém-nascidos os níveis intestinais de protease são baixos. A idade esta relacionada também à produção de muco intestinal, à taxa de renovação das células epiteliais e conseqüente absorção de fluídos, fatores que afetam a infecções por rotavírus (RAMIG, 2004). 


\section{7 DIAGNÓSTICO LABORATORIAL}

A infecção causada pelos rotavírus não gera sintomas característicos e específicos o suficiente para que se possa fechar um diagnóstico apenas com base em sintomatologia, uma vez que outras infecções virais também causam quadros clínicos de gastroenterites e sintomas semelhantes ao causados durante uma infecção por rotavírus (ESTES e KAPIKIAN, 2007).

Alguns fatores relacionados às características das infecções por rotavírus levaram ao desenvolvimento de inúmeras técnicas de diagnóstico baseadas na identificação direta de partículas ou antígenos virais nas fezes. A grande dificuldade encontrada para cultivar estes vírus e, além disso, o grande número de partículas virais $\left(10^{9}\right.$ a $10^{11}$ partículas $/ g$ de fezes) encontrado nas fezes durante um período relativamente longo (de 5 a 7 dias) possibilitaram o desenvolvimento destas técnicas diretas de diagnóstico.

Desde sua identificação em 1973, a técnica de ME têm sido muito usada para a identificação direta de rotavírus. Esta técnica ainda é freqüentemente utilizada para resolver discrepâncias de resultados obtidos por outras técnicas, já que permite a detecção em $80 \%$ a $90 \%$ das amostras positivas (BRANDT et al., 1981; LANDAETA et al., 2003). Entretanto o uso rotineiro da ME torna-se inviável quando se trata do diagnóstico de um grande número de amostras (ELLENS et al., 1978). Além disso, os custos elevados do equipamento e a necessidade de pessoal especializado para a leitura são fatores que restringem o uso desta técnica. A técnica de imunomicroscopia eletrônica possui as mesmas características da microscopia eletrônica, mas tem uma maior especificidade, decorrente da utilização de anticorpos específicos antirotavírus. Entretanto sua utilização é questionada por alguns autores, diante da aparência distinta das partículas de rotavírus, facilmente identificadas sem a necessidade de usar um soro imune (SUZUKI et al., 1987; ESTES e KAPIKIAN, 2007).

Um dos métodos imunológicos mais usados no diagnóstico das rotaviroses tem sido o ensaio imunoenzimático (EIE); esta é uma técnica muito específica e sensível e a sua especificidade pode ser ampliada pela utilização de anticorpos monoclonais. Sua utilização é facilitada pela grande comercialização de "kits" (ELLENS, et al., 1978; PEREIRA et al., 1985; 
YOLKEN, et al., 1977). Além disso, este método tem sido largamente utilizado para se fazer a caracterização sorológica de subgrupo e sorotipo de amostras do grupo A, utilizando-se anticorpos monoclonais (MAb) (GREENBERG et al., 1983; LIPRANDI et al., 1990). Esta técnica possui vantagens como a possibilidade de automação para a triagem de grande quantidade de amostras e por outro lado, não necessita de muitos equipamentos, permitindo a aplicação também em pequena escala.

Alguns laboratórios possuem como rotina o uso de outros métodos como: contraimunoeletroforese, eletroforese do RNA viral, aglutinação em látex, co-aglutinação, hemaglutinação reversa (RPHA) e testes de hibridização em membrana. Atualmente existem inúmeros "kits" comerciais viáveis baseados nestas técnicas, entretanto deve-se ficar atento a "kits" que não possuam reagentes confirmatórios evitando assim falsos positivos (ESTES e KAPIKIAN, 2007).

Deve-se lembrar que atualmente já existem alguns testes imunoenzimáticos desenvolvidos para a detecção de rotavírus dos grupos $\mathrm{B}$ e C. Estes testes, a exemplo dos existentes para o grupo $A$, são voltados não só para a identificação dos antígenos virais como também para os anticorpos (JAMES et al., 1998).

A eletroforese em gel de poliacrilamida (EGPA) ainda tem sido muito utilizada na identificação do genoma composto de 11 segmentos de dsRNA, característico dos rotavírus (HOULY et al., 1986; PEREIRA et al.,1983). Devido a esta característica de genoma segmentado, o padrão eletroforético tem sido usado para identificar e diferenciar amostras de vírus, sendo útil em estudos epidemiológicos (ALFIERI et al., 1994; STEWEIEN et al., 1994), possibilitando, por exemplo, a monitoração de padrões de transmissão dos rotavírus, a determinação da prevalência de determinadas amostras virais, em diferentes localidades e épocas do ano (CARDOSO et al., 1989; GATTI et al., 1989), e a determinação da origem de surtos de diarréias causadas por rotavírus (BITTENCOURT e RÁCZ., 1992; THEIL e McCLOSKEY, 1989). Além disso, esta técnica ainda é uma das maneiras de se fazer a identificação de rotavírus dos grupos não-A, que não podem ser identificados pela maioria das técnicas 
sorológicas disponíveis (GATTI et al., 1989; McCRAE,1987; SAIF e JIANG,1994).

Os rotavírus dos grupos não-A exibem perfis distintos, permitindo sua identificação preliminar e sugestiva, pela ausência do grupo III que inclui os segmentos 7, 8 e 9, encontrado nos rotavírus do grupo A (PEREIRA et al.,1983; SAIF e JIANG,1994). Nestes vírus, este grupo é, em geral, composto por dois segmentos de dsRNA.

Durante muito tempo a EGPA, foi usada também para a diferenciação sorológica dos rotavírus do grupo $A$. Inicialmente, acreditava-se que havia uma relação entre a especificidade de subgrupo de rotavírus humanos do grupo $A$, e o perfil eletroforético do RNA viral. Rotavírus com um perfil eletroforético do dsRNA do tipo "curto", em que os segmentos do grupo IV (10 e 11) migravam mais lentamente no gel, eram considerados como sendo do subgrupo I e rotavírus com perfil eletroforético do dsRNA do tipo "longo", eram considerados como pertencentes ao subgrupo II (BEARDS, 1982; MASCARENHAS et al., 1989; BINGNAN et al., 1991). Entretanto, amostras classificadas sorologicamente como sendo do subgrupo I têm apresentado perfil eletroforético longo do dsRNA e amostras do subgrupo II, perfil "curto" (MASCARENHAS et al., 1989). Desta forma, o perfil eletroforético do dsRNA do rotavírus não deve ser usado para a classificação sorológica dos rotavírus do grupo A. Para a determinação de subgrupo e sorotipo, as reações sorológicas ou moleculares específicas são imprescindíveis.

A dificuldade de cultivo dos rotavírus e o desenvolvimento de inúmeras técnicas de biologia molecular tais como a reação em cadeia pela polimerase (PCR) e a análise da seqüência de nucleotídeos levou a um rápido aumento do número de informações sobre a etiologia das rotaviroses, fornecendo dados específicos e completos sobre os rotavírus circulantes em todo o mundo (GOUVEA et al., 1990; 1994 a e b; GENTSCH et al., 1992; RÁCZ et al., 2000). O sequenciamento genômico muitas vezes completa ou certifica resultados obtidos por outras técnicas, além de fornecer dados que permitem o estudo evolutivo (genealógico ou filogenético) dos rotavírus circulantes em dada região, reforçando e ampliando dados epidemiológicos sobre estes vírus (GAULT et al., 1999; ADAH et al., 2002; MARTELLA, et al., 2005). Além disso, 
espécimes colhidos nos primeiros quatro dias de do início dos sintomas são facilmente detectáveis por EIE ou EM. Contudo, amostras colhidas até três semanas após o surgimento dos sintomas dependendo do tempo de duração podem ser identificadas por técnicas mais sensíveis, como a RT-PCR.

$O$ recente desenvolvimento da técnica de $P C R$ em tempo real $e$ adaptação aos protocolos de diagnostico de rotavírus possibilitarão a utilização da técnica de RT-PCR de maneira mais ampla, já que esta técnica dispensa a eletroforese, permitindo a rápida e fácil interpretação dos resultados. Um exemplo disto é descrito em 2006 por Logan et al. demonstraram um aumento de $111 \%$ na deteç̧ão de amostras positivas para rotavírus quando comparadas às técnicas de RT-PCR em tempo real e aglutinação em látex (LOGAN et al., 2006). Em 2004, Pang et al. observaram que ao analisarem amostras através da técnica de RT-PCR em tempo real foram detectadas rotavírus em 123 amostras, enquanto que o RT-PCR convencional identificou apenas 113 amostras. Ambas as técnicas foram mais eficientes na detecção dos rotavírus quando comparadas a ME que detectou apenas 79 amostras positivas para rotavírus (PANG, et al., 2004).

\subsection{IMUNIDADE}

Os mecanismos responsáveis pela imunidade nas infecções por rotavírus ainda não foram completamente entendidos, especialmente nos seres humanos onde os estudos sobre o papel dos anticorpos do soro forneceram resultados conflitantes (ESTES e KAPIKIAN, 2007). Os modelos animais têm sido amplamente utilizados para fornecer respostas sobre a importância da imunidade sistêmica e local durante a infecção por rotavírus (SAIF e JIANG, 1994; WARD, 1996).

De acordo com Paul e Lyoo (1993), parece existir uma resistência natural à infecção por rotavírus relacionada com a idade, onde animais neonatos de diversas espécies mostraram-se susceptíveis enquanto os animais mais velhos foram resistentes à diarréia por rotavírus.

Após experimento realizado em bezerros, foi observado que esses animais freqüentemente desenvolvem quadros de diarréia por rotavírus, apesar de possuírem altos níveis de anticorpos circulantes derivados do colostro 
(WOODE et al., 1975). Estas observações sugerem que os anticorpos presentes no lúmen do intestino delgado são os primeiros determinantes da resistência contra rotavírus, mesmo que os anticorpos sanguíneos tenham falhado na proteção das rotaviroses.

O papel das proteínas virais VP6, VP4 e VP7 tem sido avaliados durante a realização de várias pesquisas apesar da proteína VP6 ter sido reconhecida como a mais imunogênica. Outros estudos demonstraram que anticorpos séricos contra as proteínas VP4 e VP7 podem proteger os indivíduos susceptíveis (OFFIT e Blavat, 1986; HOSHINO et al., 1988). A análise dos anticorpos neutralizantes contra as proteínas VP4 ou VP7 de rotavírus têm revelado que ambas as proteínas possuem epítopos sorotipo-específico (ESTES e KAPIKIAN, 2007).

Estudos relacionados aos anticorpos anti-rotavírus na saliva, nas fezes e no soro têm sido realizados com a finalidade de investigar a existência de correlações imunológicas de proteção, tendo sido observado que: (a) os níveis de IgA séricos possuem correlação com a resistência à doença severa (HJELT et al., 1987); (b) existe correlação direta entre os altos níveis de anticorpos do tipo IgA intestinal com o nível de proteção contra infecções por rotavírus e contra a doença, em crianças e em animais (COULSON et al., 1992); (c) a infecção natural primária pelos rotavírus parece fornecer proteção contra a forma severa da doença, não somente após a reinfecção com o mesmo vírus, mas também se a reinfecção ocorrer com um vírus de outro sorotipo (VELAZQUEZ et al., 1996); (d) infecções repetidas com o mesmo sorotipo $G$ podem ocorrer, mas a probabilidade é menor, sugerindo uma proteção homotípica (ESTES e KAPIKIAN, 2007); (e) em geral, as amostras de rotavírus homólogas são mais potentes do que as heterólogas na indução da resposta imune humoral local (WARD, 1996). 


\section{9 EPIDEMIOLOGIA}

Os rotavírus são considerados em quase todo o mundo como o principal agente etiológico causador de diarréias. Em 2003, Parashar et al., concluiu que a cada ano os rotavírus infectam 111 milhões de crianças com menos de cinco anos, que apresentam quadros clínicos de diarréia e são tratadas em casa; 25 milhões de crianças a cada ano procuram tratamento médico e 2 milhões de crianças nesta faixa etária são hospitalizados; são observadas 440 mil mortes entre os casos mais graves ou seja, 1.205 mortes por dia em todo o mundo. Em países extremamente pobres os rotavírus são responsáveis por $82 \%$ das mortes em crianças com menos de cinco anos (PARASHAR et al., 2003).

Estudos epidemiológicos sobre as infecções por rotavírus são nítidos indicadores quanto à relevância que assumem esses agentes nas gastroenterites virais. (LINHARES, 2000). Apesar dos rotavírus serem o agente etiológico mais freqüentemente associado a casos graves de diarréias em crianças de todo o mundo, as taxas mais altas de mortalidade associadas à esta doença são observadas nos países em desenvolvimento. Apesar da alta freqüência de infecções causadas por rotavírus em países desenvolvidos, as taxas de mortalidade associados a esta doença é muito baixa (ESTES e KAPIKIAN, 2007). Nos EUA estima-se que os rotavírus sejam responsáveis por cerca de 3 milhões de casos anuais e apenas de 20 a 40 casos são fatais, ou seja 1 morte a cada 100 mil crianças infectadas nos primeiros 5 anos de vida. Além disso, esta doença representa um alto custo social, resultado das 500 mil visitas médicas, de 60 a 70 mil hospitalizações, falta dos responsáveis ao trabalho para acompanhar as crianças ao médico, etc, acarretando um custo estimado de cerca de 1,5 bilhões de dólares.

Em paises em desenvolvimento os rotavírus também são apontados como o principal agente em casos de diarréias severas que representam risco de morte; nestas regiões estima-se que ocorram mais de 100 milhões de casos, e cerca de 20 milhões não são encaminhados aos hospitais e que ocorram de 454 a 705 mil mortes. Estudos desenvolvidos na Ásia, África e América Latina demonstram que de $25 \%$ a $55 \%$ das hospitalizações de crianças até cinco anos de idade estejam relacionadas às infecções por rotavírus e cerca de $80 \%$ destas mortes ocorrem na Ásia e África. 
Na América Latina, estima-se que ocorram cerca de 75 mil de casos de diarréia, e aproximadamente 15 mil mortes por ano em crianças menores de cinco anos, isto corresponde de 6600 a 9000 mortes por dia (LINHARES, 2000). Kane et al. (2004) demonstraram que os rotavírus são a maior causa de hospitalização e de visitas ambulatórias entre os pacientes com diarréia. Além disso, a grande maioria das internações (65-85\%) ocorre com crianças ainda no primeiro ano de vida (KANE et al., 2004). Por outro lado, é observada uma grande variação na porcentagem de casos de rotavírus tanto em pacientes ambulatoriais (4-42\%), como em pacientes internados (16-52\%) (KANE et al., 2004); esta grande faixa de variação é semelhante aos achados de alguns estudos como o realizados por O'Rayan et al. que obtiveram dados variando de $38 \%$ das hospitalizações na Venezuela até $70 \%$ na Argentina (O'RYAN et al., 2001). No Paraguai Coluchi et al. descreveram uma prevalência de $31,8 \%$ (COLUCHI et al., 2002), enquanto que Parra et al. 2005, em um estudo realizado também no Paraguai, descreveu a ocorrência de $22,6 \%$ de rotavírus entre as amostras estudadas (PARRA et al., 2005).

No Brasil, a freqüência de diarréias associada a rotavírus varia de $12 \%$ a $42 \%$ e o Ministério da Saúde estima que hoje cerca de 2.500 crianças de menos de cinco anos morrem desse mal (LINHARES, 2000). Sabe-se que pelo menos $2 / 3$ dos processos diarréicos por rotavírus se situam na faixa etária de 6 a 24 meses de vida, embora mereça registro a relativa freqüência das infecções sintomáticas durante o primeiro semestre de vida. (LINHARES; 2000).

A infecção nosocomial por rotavírus é descrita freqüentemente (GLEIZES et al., 2006), em crianças menores de cinco anos de idade. Em alguns países europeus, os rotavírus representam o principal agente etiológico de diarréia nosocomial, representando de $31-87 \%$ dos casos (GLEIZES et al., 2006). De um modo geral, em países desenvolvidos $27 \%$ dos casos de rotaviroses podem ser associados a infecções adquiridas no ambiente hospitalar. Nos países em desenvolvimento isto ocorre em $32 \%$ dos casos. As infecções nosocomiais estão também associadas à ocorrência de rotaviroses em creches e enfermaria neonatais em todo o mundo. Uma proporção significativa de 20 a $40 \%$ das infecções é assintomática, e isto contribui para 
propagação do vírus e reduz a eficiência das medidas de prevenção (GLEIZES et al., 2006). Casos graves de epidemias nestes ambientes foram relatados nos EUA e Itália (ESTES e KAPIKIAN, 2007). Em um estudo publicado em 2006, Delpiano et al. (2006) ao compararem as incidências e os custos das infecções de origem comunitária e nosocomial por rotavírus concluiu que, em um período de um ano, o número casos de infecção nosocomial por rotavírus ocorreu em 52 pacientes, enquanto o número de pacientes internados com rotavírus de origem externa ao hospital foi de 78 casos; isto demonstra a importância da ocorrência de infecções nosocomiais. Entretanto, neste caso, é importante considerar que os dados apresentados por este grupo foram obtidos utilizandose a técnica de EGPA para a identificação dos rotavírus nos dois grupos de pacientes. Além disso, neste trabalho foi observado que o pico de infecções nosocomiais foi posterior ao pico de infecções na comunidade (DELPIANO et al., 2006). Em Calcutá, na Índia 80,5\% dos casos de diarréia nosocomial foram associados a rotavírus. Estes casos, apesar de apresentarem um quadro clínico menos grave que o quadro observado por crianças infectadas fora do ambiente hospitalar, teve um custo maior para a instituição (DUTTA et al., 1992).

Em adultos, as reinfecções por rotavírus são normalmente caracterizadas por um mínimo ou nenhum quadro clínico. Estudos demonstraram que adultos que cuidam de crianças hospitalizadas com rotaviroses demonstram variações sorológicas que podem ser associadas a infecções recentes por rotavírus. Epidemias ou surtos foram observados em pacientes idosos (AWACHAT e KELKAR 2006), instituições de reabilitação (LIJIMA, et al. 2006) em recrutas do exército finlandês e equipes de hospitais em varias regiões do mundo (ESTES e KAPIKIAN, 2007). Em idosos, podem ser observados casos graves e até fatais. Em 2006, Feeney et al. relataram surtos de rotavírus dos genótipos G1P[8], G9P[8] e G4P[8] em idosos acarretando casos graves de diarréia, na Irlanda. Porém estas epidemias são pouco usuais devido à alta taxa de imunidade para rotavírus observada na maioria dos adultos. Rubilar-Abreu et al. observaram na Suécia uma alta taxa de positividade para rotavírus G9 entre 1517 amostras de pacientes com mais 
de 15 anos, o que sugere que certos sorotipos emergentes possam vir a infectar adultos sadios de forma sintomática (RUBILAR-ABREU et al., 2005).

Os rotavírus do grupo B e C também são freqüentemente associados a epidemias graves em adultos, especialmente na China (CHEG,1985; KOBAYASHI, et al., 2001), entretanto foi identificado em vários paises associados a sintomas em adultos, como por exemplo na Índia (KELKAR e ZADE, 2004), Bangladeshe (RAHMAN et al., 2005) e na Suécia (NILSSON et al., 2000).

Os rotavírus podem infectar, além do homem, uma grande variedade de espécies animais, como descrito anteriormente. A alguns dos pesquisadores acreditam ser pouco provável para um rotavírus específico de qualquer outra espécie infectar humanos, uma vez que a maioria dos genes não apresenta um grau de identidade tão grande quanto a observada entre cepas que infectam a mesma espécie (COOK et al., 2004).

Entretanto, já há algum tempo alguns estudos demonstram a possibilidade de ocorrerem rearranjos genômicos ("reassortment") espontaneamente na natureza (GARBARG-CHENON et al., 1986; WARD et al., 1990). Novos estudos também relatam ser possível a transmissão entre diferentes espécies inclusive entre o homem e diversos animais, caracterizando os rotavírus como uma zoonose (GENTSCH et al., 2005; COOK et al., 2004; PALOMBO et al., 2002; MULLER e JOHNER 2007). Alguns destes trabalhos relatam a ocorrência de rearranjos in vivo, possibilitando a troca de segmentos genômicos durante a replicação (ITURRIZA-GOMARA et al., 2001; MAUNULA e VON BONSDORFF, 2002); este processo poderia ser resultado de coinfecção inter ou intra-específica.

Apesar da grande diversidade genética descrita para os rotavírus alguns sorotipos/genótipos são considerados mais freqüentes em determinadas espécies. Os quatro sorotipos/genótipos $G$ reconhecidos como de grande importância epidemiológica universal em humanos são: o G1, G2, G3 e o G4. (GENTSCH et al., 1996). No Brasil, Linhares, et al. (1996) observou a seguinte freqüência: $65 \%$ para $\mathrm{G} 1,30 \%$ para $\mathrm{G} 2,1,2 \%$ para $\mathrm{G} 3,4,6 \%$ para $\mathrm{G} 4$ e $1,2 \%$ para G9, demonstrando assim que outros genótipos estão circulantes. Além destes, genótipos G5 (GOUVEA et al., 1994), G12 (PIETRUCHINSKI et al., 
2006) tem sido identificados com uma certa freqüência em trabalhos realizados no Brasil. Um outro dado importante é a clara emergência do genótipo G9, descrito recentemente em um grande número de casos no Brasil (CARMONA et al., 2006; SANTOS et al.,2003; Araújo et al.,2001) e também em outros países como Paraguai (COLUCH et al., 2002), Austrália (PALOMBO et al., 2000), Estados Unidos (COULSON et al., 1999), África (STEELE et al., 2003), Bangladesh (AHMED et al., 2006), Líbia, Kênia, Cuba (CUNLIFFE et al., 2001). Outros genótipos $G$ também foram identificados em humanos em várias regiões do mundo. O genótipo $\mathrm{G} 6$ foi identificado em humanos na Europa, Índia, América do Norte e Austrália, o genótipo G8 foi identificado em amostras humanas na América do Sul, África, Ásia, Europa e Austrália; o genótipo G10 na Ásia; e o G12 na África, Ásia e América do Norte (SANTOS e HOSHINO, 2005 CASTELLO et al.,2004).

Em relação aos sorotipos/genótipos $P$ os mais freqüentemente identificados em crianças no mundo todos são P1A[8], P1B[4] e P2A[6]. No Brasil, estes genótipos também são freqüentemente identificados, além disso, o genótipo P[9] também foi descrito (LEITE et al., 1996; SANTOS et al., 2001; SANTOS et al., 2002). Este genótipo foi descrito também na África, Ásia, América do Norte e Europa. Ao redor do mundo outros genótipos $P$ também têm sido associados a infecções em humanos, tais como o genótipo $P[3]$ identificado na Ásia e América do norte; o P[10] descrito na África; o genótipo $\mathrm{P}[11]$ descrito na Ásia; o genótipo P[14] descrito na África, Ásia, Europa e Austrália e por fim o P[19] descrito na Ásia (SANTOS e HOSHINO, 2005).

Mundialmente, as combinações mais comuns entre genótipos $\mathrm{G}$ e $\mathrm{P}$ são: G1 P[8] (53\%), G4 P[8] (14,3\%), G2 P[4] (10,7\%) e finalmente G3 P[8] (5,4\%) (SANTOS e HOSHINO, 2005; GENTSCH et al., 2005; CASTELLO et al.,2004)). Entretanto vários trabalhos têm demonstrado a presença de combinações incomuns entre os diferentes genótipos, tanto intra-específicos como combinações entes genótipos $P$ e $G$ freqüentemente observados em espécies diferentes (Figura 6). Alguns exemplos são as combinações dos genótipos G1P[4], G2P[6], G3P[6]; G5P[8], G8P[6], G9P[10], G10P[14], G12P[6] etc (SANTOS e HOSHINO, 2005; GENTSCH et al., 2005). 


\begin{tabular}{|c|c|c|c|c|c|c|c|c|c|c|c|}
\hline \multirow[b]{2}{*}{$\begin{array}{l}\mathbf{G} \\
\text { type }\end{array}$} & \multicolumn{11}{|c|}{ P serotype [genotype] } \\
\hline & $\frac{1 \mathrm{~A}[8]}{7}$ & $1 \mathrm{~B}[4]$ & $2 \mathrm{~A}[6]$ & $2 \mathrm{C}[6]$ & $3[9]$ & $4[10]$ & 5A[3] & $6[1]$ & 8[11] & $11[14]$ & 12[19] \\
\hline 1 & Wa & AU64 & M37 & AU19 & K8 & & & & & & \\
\hline 2 & & DS -1 & 1076 & & & & & & & & \\
\hline 3 & P & 107E1B & McN13 & & AU.1 & & HCR3 & & $157 \mathrm{C}$ & & \\
\hline 4 & Hochi & & ST-3 & & & & & & & & \\
\hline 5 & Br1054 & & & & & & & & & & \\
\hline 61 & & & & & PA151 & & & & & PA169 & \\
\hline 87 & & MW333 & MW023 & & & $69 \mathrm{M}$ & & & & HAL1166 & \\
\hline 9 & W161 & & US1205 & & & & & & $116 \mathrm{E}$ & & Mc 323 \\
\hline $10 \tau$ & & & & & & & & & 1321 & Mc 35 & \\
\hline 12 & & & US585 & & & & & & & & \\
\hline
\end{tabular}

Globally common

Regionally common
Uncommon

Neonates

Figura 6: Combinações genótipos $P$ e $G$ de rotavírus isolados em crianças com diarréia, incluindo as combinações pouco usuais, distribuição regional, etária e espécie comumente identificada. Fonte: GENTSCH et al. 2005.

O grande grau de diversidade cepas de rotavírus, particularmente em alguns países, sugerem que as co-infecções com sorotipos diferentes possam ocorrer com freqüência. Estas co-infecções são observadas ao visualizarem-se dois perfis do dsRNA em uma mesma amostra. Os resultados de genotipagem através de RT-PCR e de sorotipagem confirmam a presença de mais de um genótipo. Os níveis mais elevados de detecção de infecções mistas estão freqüentemente associados a países onde números mais elevados do genótipos diferente são encontrados. Na Índia, por exemplo, um estudo multicentrico identificou cerca de 9 combinações de genótipos entre as amostras identificadas como rotavírus de uma mesma cidade. Por outro lado, em estudos conduzidos em países desenvolvidos poucas infecções mistas foram identificadas e além disso, poucas combinações de genótipos foram detectadas em cada cidade estudada. Assim, os níveis elevados de detecção de infecção mistas ocorrem especialmente em países em desenvolvimento; nestas regiões as taxas de infecções mistas podem variar entre 5 a $10 \%$, 
enquanto que em regiões consideradas desenvolvidas a taxa é de no maximo 3,5\% (GENTSCH et al., 2005).

\subsection{PREVENÇÃO E CONTROLE}

Estima-se que a vacinação de crianças contra infecções por rotavírus seria capaz de prevenir a morte de 352000 a 592000 de crianças a cada ano (GLASS et al., 2005). Há mais de duas décadas a Organização Mundial da Saúde - OMS (World Health Organization -WHO) e Aliança Global para vacinação e imunização (Global Aliance for Vacination and Imunization - GAVI) identificaram a vacina de rotavírus como uma das prioridades a serem desenvolvidas (PARASHAR et al., 2003), especialmente visando a vacinação em regiões da África, Ásia, Índia e China, onde ocorrem 90\% das mortes (GLASS et al., 2005).

A primeira vacina humana testada era constituída por uma amostra bovina (RIT4237) sorotipo G6, naturalmente atenuada para a espécie humana, e foi administrada por via oral em crianças na Finlândia, em 1983. Esta vacina mostrou uma eficácia superior a $80 \%$ em crianças vacinadas. Porém, em testes subseqüentes, em países em desenvolvimento, a vacina mostrou uma reduzida eficácia e imunogenicidade, sendo então descontinuada (VESIKARI et al., 1985; KANG, 2006). A partir do sucesso inicial obtido com a vacina de vírus vivos atenuados, administrado por via oral, várias outras candidatas a vacinas de rotavírus foram desenvolvidas utilizando diferentes abordagens.

Estratégias utilizando amostras vivas atenuadas de origem animal (Bo/WC3, Si/RRV) ou humana (M37, RV3) e amostras recombinantes de vírus símios-humanos e bovinos-humanos, monovalentes ou não, já foram testadas (KANG, 2006; BRESSE et al., 2005).

A primeira vacina que completou os testes clínicos e foi liberada foi a vacina tetravalente RRT (Rotashield ${ }^{\mathrm{TM}}$, Wyeth Lederle Vaccines, Philadelphia). Esta vacina demonstrou, durante os teste clínicos, alta eficiência (90\%) contra casos graves de diarréia por rotavírus, e 60\% contra todos os casos de infecções por rotavírus (BERNSTEIN et al., 1995). Foi licenciada em outubro de 1998 nos Estados Unidos e recomendada para uso oral, em 3 doses, aos 2, 4 e 6 meses de idade, a um custo de 38 dólares por dose (RENNELS et al., 1996; 
GLASS et al., 2005). A vacina RRT era composta por quatro vírus vivos, sendo três recombinantes e um atenuado, correspondendo aos quatro sorotipos rotavírus humanos mais importantes. A vacina era constituída pelas cepas MMU18006 de macaco Rhesus (com especificidade para o sorotipo G3 humano) e três cepas recombinantes de humano - Rhesus, que contém um único gene humano (VP7) inserido, correspondendo aos sorotipos G1, G2 e G4 humanos (PEREZ-SCHAEL et al., 1997; HOCHWALD et al., 1999). Nove meses após sua liberação, aproximadamente 600 mil crianças foram vacinadas e 1.800.000 doses já haviam sido ministradas (GLASS et al., 2005; CDC, 1999a).

Em junho de 1999, 15 casos de intussuscepção foram diagnosticados em crianças, duas semanas após a vacinação. Em julho deste ano, o Centro de Controle e Prevenção de Doenças (CDC Center for Diseases Control and Prevention), Atlanta, Geórgia, Estados Unidos, suspendeu temporariamente o uso da Rotashield ${ }^{\mathrm{TM}}$ (RRV-TV) em território americano, com base em relatos sobre a ocorrência de intussuscepção entre crianças vacinadas (RENNELS et al., 1998; CDC, 1999b).

Em outubro de 1999, um total de 98 casos de intussuscepção foram reportados ao GAVI, sendo que 60 ocorreram sete dias após a aplicação da primeira, segunda ou terceira dose da vacina. Estes casos foram descritos por Zanardi et al. (2001). Após estes episódios o Comitê Assessor para a Prática de Imunizações (ACIP Advisory Committee on Inmunization Practices) optou por cancelar a recomendação de uso da RRV-TV, recomendando mais estudos que pudessem relacionar a vacina aos casos de intussuscepção (MURPHY et al., 2001).

Até hoje existem controvérsias a este respeito. Em estudo iniciado antes da suspensão do uso da vacina, estabeleceu-se evidência de associação entre a vacinação com RRV-TV e intussuscepção (ESTES e KAPIKIAN, 2007; LYNCH et al.,2006). Por outro lado, estudos recentes sugerem que exista uma sazonalidade nos casos de intussuscepção que demonstrou ter um pico na primavera ou nos meses seguintes ao pico das infecções e hospitalizações relacionadas a rotavírus. A estimativa exata do risco de intussuscepção relacionada à vacina contra rotavírus é importante para um conhecimento mais 
completo desta condição e para o desenvolvimento futuro de novas vacinas (PETER et al., 2002).

Além das vacinas com vírus inativados, outras tecnologias também têm sido empregadas na tentativa de desenvolver uma vacina para rotavírus eficiente e segura: vacinas constituídas por partículas íntegras ou partículas com cápside vazio, produzidas por técnicas de biologia molecular, onde proteínas neutralizantes são expressas em vetores, ou vacinas de polipeptídios sintéticos (BRESSE et al., 2005; KANG, 2006).

Atualmente sete vacinas para rotavírus, de administração por via oral são consideradas promissoras. As vacinas RotaTeq ${ }^{\circledR}$, Rotarix $®$, Rhesus tetravalente e LLR estão licenciadas em diferentes países. As vacinas RV3 e a vacina bovina recombinante Uk estão na fase dois de testes. E por fim, a vacina indiana neonatal encontra-se na fase um. Entre as sete duas estão licenciadas nos EUA pelo FDA, a RotaTeq ${ }^{\circledR}$ e a Rotarix $\AA$ e ambas têm demonstrado comprovada eficácia em prevenir formas graves de infecção por rotavírus em estudos clínicos (GLASS et al., 2005: KANG, 2006).

A vacina LLR monovalente utiliza a cepa Lanzhou de cordeiro (LLR) com genótipo $\mathrm{P}[12] \mathrm{G} 10$, produzida pelo instituto de Lanzhou e licenciada na China em 2000. Durante os testes clinico, crianças de 6 a 24 meses, após receberem uma única dose da vacina apresentaram uma boa resposta imune e sem evento adverso associado (WHO, 2000). Esta vacina está liberada apenas na China e está disponível em algumas partes do país, entretanto não está incluída em programas nacionais de immunização (LYNCH et al., 2000; KANG, 2006).

A vacina quadrivalente RRV é baseada na vacina Rotashield $\AA$, composta da mesma cepa foi licenciada agora pela BioVirx, EUA. (KANG, 2006; GLASS et al., 2005).

A vacina pentavalente bovino-humana (internacionalmente conhecida por RotaTeq $\AA$, produzida pelo laboratório Merck, EUA contém cinco vírus geneticamente obtidos a partir de um rearranjo. Cada um dos cinco vírus presente na vacina é produzido pela combinação de 10 genes de uma cepa bovina com um genes de cepas humanas, gerando cinco vírus predominantemente bovinos que espressam uma proteína da cepa humana. $\mathrm{O}$ 
resultado final é uma vacina pentavalente que oferece proteção contra os genótipos G1, G2, G3, G4 e P1A[8]. Estes cinco sorotipos representam 75\% dos casos de rotavírus isolados em todo o mundo. No total, os estudos da RotaTeq ${ }^{\circledR}$, envolveram mais de 72000 crianças e este número foi concebido para verificar a ocorrência de intussuscepção. Os resultados demonstraram eficácia para proteção contra qualquer gastrenterite por rotavírus de $74 \%$ e $98 \%$ em formas graves de infecção. Além disso, durante a fase de testes a vacina demonstrou não aumentar o risco de intussuscepção para os lactentes que foram vacinados. A vacina é administrada por via oral em três doses: aos dois, quatro e 6 meses de idade. Esta vacina esta licenciada nos EUA desde fevereiro de 2006 e também no México e aguarda o licenciamento na Europa e no Brasil. O ACIP passou a recomendá-la para os lactentes (VESIKARI et al., 2006b).

A outra vacina comercializada atualmente e licenciada também no Brasil é a vacina monovalente de cepa humana Rotarix $\AA$, do laboratório GSK. A vacina é constituída de uma cepa monovalente P1A[8], G1 de rotavírus humano atenuado em cultura celular e propicia proteção cruzada contra outros sorotipos. Os resultados do estudo pré-clínicos demonstram uma eficácia de cerca de $70 \%$ em prevenir qualquer forma de gastrenterite por rotavírus e de $85 \%$ em prevenir formas graves, não sendo também associada a um aumento no risco de intussuscepção (GLASS et al., 2006). Estes estudos demonstraram também que ocorre proteção eficiente contra sorotipos diferentes do sorotipo vacinal.

Esta vacina foi incorporada ao Programa Nacional de Imunizações (PNI) Brasileiro e a sua aplicação rotineira iniciou-se em março de 2006 (http://portal.saude.gov.br/saude/). A partir desta data, o Ministério da Saúde oferece através do Sistema Único de Saúde (SUS), a vacina contra rotavírus ministrada em duas doses gratuitas: uma aos dois meses de idade e outra aos quatro meses. O Brasil foi o primeiro país a incluir a vacina contra o rotavírus em seu sistema público de saúde.

Avaliações da eficácia em longo prazo das vacinas requerem também uma maior compreensão da diversidade antigênica e genética dos rotavírus selvagens, especialmente da VP7. De acordo com a emergência de novos 
sorotipos, pode ser necessária a inclusão de grande variedade de cepas nas futuras formulações. A seleção das cepas deve também levar em consideração o aparecimento de novas variantes imunológicas. As formulações deveriam variar de acordo com a região geográfica, para cobrir a diversidade local de cepas. A seleção imunológica causada por imunizações de larga escala pode resultar na emergência de mutantes de escape. A caracterização sorológica e molecular de amostras de rotavírus tem, portanto, importância fundamental para definir a extensão da diversidade das amostras de rotavírus circulantes (ESTES e KAPIKIAN, 2007).

Enfim, o efeito que a diversidade da população viral terá no sucesso das vacinas contra as rotaviroses em humanos, e a implicação da vacinação em massa na evolução viral precisa ser acompanhada por estudos epidemiológicos contínuos dos isolados clínicos antes e depois da introdução de programas de vacinação. Ao adotar como forma de controle das rotaviroses a vacinação, é necessário que se mantenha o monitoramento contínuo das amostras prevalentes em nosso país, bem como se conheça todo o histórico e diferenças da infecção ao longo do tempo e em grupos socialmente distintos. 


\section{OBJETIVOS}

Os objetivos do presente trabalho são:

- Identificação rotavírus em amostras de fezes de crianças atendidas no Hospital Universitário/USP, no período compreendido entre março de 1994 e fevereiro de 1996.

- Caracterização do perfil eletroforético do genoma dos rotavírus identificados nestas amostras.

- Caracterização sorológica de grupo, subgrupo e sorotipo de rotavírus das amostras positivas.

- Caracterização molecular das amostras de rotavírus quanto aos genótipos G e P.

- Caracterização molecular de amostras positivas para rotavírus coletadas de fevereiro a outubro de 2000, por um laboratório particular.

- Analisar o número de amostras positivas por faixa etária dos pacientes dos dois grupos de amostras.

- Analisar a sazonalidade da infecção por rotavírus nos dois grupos de amostras.

- Comparar a diversidade dos genotipos G e P identificados nestes dois grupos de amostras.

- Realizar a caracterização molecular, através da análise de seqüência de nucleotídeos do cDNA de amostras com genotipos não comuns. 


\section{MATERIAL E MÉTODOS}

\subsection{Amostras de fezes}

Durante o presente trabalho foram analisados um total de 350 amostras de fezes divididas em dois grupos de amostras, o primeiro composto por 187 amostras de fezes de crianças com idade variando entre zero e cinco anos. Estas amostras foram coletadas no ambulatório do Hospital Universitário (HU), da Universidade de São Paulo (USP-SP), entre os meses de Março de 1994 a fevereiro de 1996. Entre as amostras estudadas, 157 foram coletadas de crianças com diarréia aguda e 30 amostras foram coletadas de crianças sem diarréia usadas como casos controle. O segundo grupo era composto por 163 amostras de fezes de crianças e adultos de idades variadas, caracterizadas como positivas para rotavírus, em um Laboratório particular localizado na cidade de São Paulo. Estas amostras foram enviadas ao Laboratório de Virologia Alberto neves Candeias para estudo molecular. Tendo sido coletadas de pacientes que se submeteram a exames laboratoriais para diagnóstico de rotavírus e apresentaram resultado positivo. Estas amostras foram coletadas entre os meses de Janeiro a dezembro de 2000.

Todas as amostras permaneceram estocadas a uma temperatura de $-20^{\circ} \mathrm{C}$ até o momento da analise.

\subsection{Amostras Padrão}

Durante este estudo, foram utilizadas várias amostras de rotavírus consideradas amostras padrão, cedidas por Dr. David Snodgrass, (Moredun Research Institute, Edinburgh, Scotland) e pelo Dr. Enzo Palombo, (WHO Collaborating Center for Research on Human Rotaviruses, Royal Children's Hospital, Melbourne, Austrália).Tabela 4. Todas amostras padrão foram propagadas em culturas celulares de 
linhagem contínua MA-104 e/ou células Caco-2, como descrito por RÁCZ et al., 1993. Estas amostras foram usadas durante todo o desenvolvimento deste estudo como amostras controles dos diferentes procedimentos, abrangendo assim diferentes subgrupos, sorotipos e genótipos conforme descrito na Tabela 4.

Tabela 4: Amostras padrão de rotavírus, cultivadas no Laboratório de Virologia, Departamento de Microbiologia, ICB-USP, com as respectivas classificações de subgrupo, sorotipos e genótipos G e P.

\begin{tabular}{lcccc}
\hline Amostra & Subgrupo & Sorotipo*/Genótipo G* & Sorotipo P* & Genótipo P* $^{*}$ \\
\hline Rv-A/Wa & $\mathrm{II}^{*}$ & 1 & $1 \mathrm{~A}$ & {$[8]$} \\
Rv-A/RV4 & & 1 & $1 \mathrm{~A}$ & {$[8]$} \\
Rv-A/DS-1 & $\mathrm{I}^{*}$ & 2 & $1 \mathrm{~B}$ & {$[4]$} \\
SiRv-A/SA11 & $\mathrm{I}^{*}$ & 3 & $5 \mathrm{~B}$ & {$[2]$} \\
Rv-A/ST3 & $\mathrm{I}^{* *}$ & 4 & $2 \mathrm{~A}$ & {$[6]$} \\
PoRv-A/OSU & $\mathrm{I}^{*}$ & 5 & 9 & {$[7]$} \\
BoRv-A/NCDV & $\mathrm{I}^{*}$ & 6 & 6 & {$[1]$} \\
BoRv-A/UK & $\mathrm{I}^{* * *}$ & 6 & 7 & {$[5]$} \\
BoRv-A/678 & & 8 & 7 & {$[5]$} \\
Rv-A/F45 & & 9 & $1 \mathrm{~A}$ & {$[8]$} \\
BoRv-A/B223 & & 10 & 8 & {$[11]$} \\
PoRv-A/YM & $\mathrm{I}^{* * *}$ & 11 & 9 & {$[7]$} \\
\hline
\end{tabular}

*(ESTES e KAPIKIAN, 2007); ${ }^{\star \star(A N A N D ~ e t ~ a l ., ~ 2000) ; ~ * \star \star(G R E E N B E R G ~ e t ~ a l ., ~ 1996) ~}$

\subsection{Preparo da suspensão das amostras de fezes}

Para a triagem, a partir das amostras de fezes foram preparadas suspensões a $20 \%$ (1:5) em tampão Tris/cálcio (Tris/HCl 0,1M; $\mathrm{CaCl}_{2}$ $1,5 \mathrm{mM} ; \mathrm{pH} 7,3)$. Após 30 minutos à temperatura ambiente, com agitações periódicas, as suspensões foram centrifugadas a $5.900 \mathrm{~g}$ em centrífuga Eppendorf (modelo 5417-R) por 15 minutos. Os sobrenadantes foram coletados e as suspensões fecais foram estocadas a $-20^{\circ} \mathrm{C}$, até o momento da analise (RÁCZ et al., 1993).

Sempre que necessário foram preparadas novas suspensões seguindo o protocolo acima. 


\subsection{Ensaio imunoenzimático para rotavírus e adenovírus (EIERA/FIOCRUZ)}

Para a triagem de amostras positivas e caracterização quanto ao grupo sorológico de rotavírus, utilizou-se o ensaio imunoenzimático do tipo "duplo sanduíche" EIARA - FIOCRUZ (PEREIRA et al.,1985). Esta metodologia foi aplicada apenas para as amostras coletadas no HU-USP.

\subsubsection{Sensibilização das microplacas}

Microplacas com 96 cavidades foram sensibilizadas com soros hiperimunes de cabra anti-rotavírus e anti-adenovírus, usados como anticorpo de captura. Ambos os soros foram diluídos em tampão carbonato - bicarbonato ( $\mathrm{Na}_{2} \mathrm{CO}_{3}$ 0,016M; $\mathrm{NaHCO}_{3}$ 0,034M pH 9,6), na diluição final de 1:10.000; em seguida, foram distribuídos $100 \mu \mathrm{l}$ em fileiras alternadas das microplacas. As microplacas foram então incubadas por 2 horas a $37^{\circ} \mathrm{C}$, ou por 18 horas a $4^{\circ} \mathrm{C}$.

\subsubsection{Lavagem das microplacas}

Entre cada uma das etapas, as microplacas foram lavadas por três vezes com 200 $\mu$ l de PBS/T (PBS 0,01M pH 7,4; Tween 20 0,05\%), aguardando-se 2 minutos entre cada lavagem. O processo foi realizado utilizando-se pipeta multicanal e aspiração por vácuo.

\subsubsection{Adição das amostras}

Após a sensibilização, distribuiu-se o diluente de amostra PBS/T/BSA/EDTA (PBS 0,01M pH 7,4; Tween 20 0,05\%; BSA 1\%; EDTA $0,1 \mathrm{M}$ ) em volume de $75 \mu$ làs colunas ímpares e de $50 \mu$ às colunas pares. A seguir, adicionou-se, as suspensões fecais testadas em duas diluições (1:4 e 1:12) em dois pares de orifícios, contendo cada par um dos anticorpos de captura. À mesma placa, foram adicionados os controles positivos de rotavírus (vírus padrão SiRv-A/SA11) e adenovírus, também testados em duas diluições (1:4 e 1:12), em dois pares de orifícios. Nesta etapa foram adicionados $75 \mu$ de PBS/T/BSA 
(PBS 0,01M pH 7,4; Tween 20 0,05\%; BSA 1\%) aos orifícios correspondentes aos controles de conjugado e substrato. As microplacas foram incubadas por 18 horas a $4^{\circ} \mathrm{C}$.

\subsubsection{Adição do soro detector}

Após a lavagem, foram adicionados, em todos os orifícios das microplacas, $100 \mu \mathrm{l}$ dos soros detectores (soro hiperimune de cobaio anti-rotavírus e soro hiperimune de cobaio anti-adenovírus), ambos diluídos a 1:10.000 em PBS/T/BSA. As placas foram novamente incubadas a $37^{\circ} \mathrm{C}$ por 2 horas.

\subsubsection{Adição do soro conjugado}

Como conjugado, foi usado um soro de coelho anti-IgG de cobaio ligado a peroxidase (Sigma A-7289), diluído a 1:10.000 em PBS/T/BSA. Foram adicionados $100 \mu \mathrm{l}$ desta diluição a todos os orifícios das microplacas, exceto nas referentes ao controle de substrato, às quais foram adicionados $100 \mu \mathrm{l}$ de PBS/T/BSA. Em seguida as placas foram incubadas a $37^{\circ} \mathrm{C}$ por 2 horas.

\subsubsection{Adição do substrato}

Após a lavagem adicionou-se $200 \mu$ da solução de substrato, composta de orto-fenilenodiamina (OPD Sigma cat. P-8287) na concentração final de $0,4 \mathrm{mg} / \mathrm{ml}$ diluído em tampão de ácido cítrico $(0,1 \mathrm{M})$ e fosfato (0,2M), pH 5,6 e água oxigenada (30 volumes a 0,156\%). Quando necessário, o pH da solução de substrato foi corrigido usando uma solução de $\mathrm{NaOH}$ a 20\%. Após o aparecimento de uma tonalidade amarela nítida nos controles de antígeno, a reação foi interrompida por adição de $25 \mu \mathrm{l}$ de ácido sulfúrico 2,0M.

\subsubsection{Leitura}

A leitura foi feita visualmente e por medida da densidade ótica em leitor espectrofotométrico (Reader Microelisa System, Organon Teknika) 
com filtro de $492 \mathrm{~nm}$. Foram consideradas positivas as amostras com densidade óticas maior ou igual ao dobro da média das densidades óticas obtidas no controle de conjugado.

\subsection{Eletroforese de RNA de rotavírus em gel de poliacrilamida} (EGPA)

A EGPA foi executada de acordo com PEREIRA et al. (1983), e os géis corados com nitrato de prata de acordo com a técnica descrita por HERING et al. (1982).

\subsubsection{Extração do ácido nucléico viral}

Em tubos tipo Eppendorf contendo $400 \mu l$ da suspensão fecal a $20 \%$ foram acrescentados $40 \mu \mathrm{l}$ de lauril sulfato de sódio (SDS) a $10 \%$, $40 \mu \mathrm{l}$ de acetato de sódio $\left(\mathrm{C}_{2} \mathrm{H}_{3} \mathrm{O}_{2} \mathrm{Na}\right) 1 \mathrm{M}$ e $400 \mu \mathrm{l}$ da solução de fenol/clorofórmio (60\% fenol; 39\% clorofórmio; 15,9\% álcool isoamílico). Após agitação de 1 minuto, os tubos foram centrifugados a $5900 \mathrm{~g}$ por 2 minutos em centrífuga Eppendorf (modelo 5417-R). Os sobrenadantes foram transferidos para outros tubos aos quais foram adicionados $800 \mu l$ de etanol absoluto estocado a $-20^{\circ} \mathrm{C}$. Após agitação os tubos foram incubados por uma noite (18 horas) a $-20^{\circ} \mathrm{C}$.

Após este período, foram centrifugados novamente a $13.800 \mathrm{~g}$ por 10 minutos em centrífuga Eppendorf (modelo 5417-R). Os sobrenadantes foram desprezados e os sedimentos foram secos com os tubos em posição invertida à temperatura ambiente por 5 minutos. Em seguida, os sedimentos foram ressuspensos em $20 \mu \mathrm{l}$ de dissociador de amostra (0,0625 M Tris/HCl, pH6,8; 5 M uréia; 3\% SDS; 5\% 2-mercaptoetanol; 0,01\% de azul de bromofenol) e incubados por 15 minutos a $56^{\circ} \mathrm{C}$. 


\subsubsection{Preparo do gel de poliacrilamida}

Foram montadas câmaras preparadas com duas placas de vidro separadas entre si por um espaçador de $1 \mathrm{~mm}$, seladas com agar $2 \%$, às quais foi adicionado o gel inferior (acrilamida $7,5 \%$ - bisacrilamida $0,2 \%$ em tampão Tris $/ \mathrm{HCl}, 3 \mathrm{mM}$ pH8,8; 0,03mM de persulfato de amônia; $0,2 \%$ de TEMED). Após sua polimerização, foi adicionado o gel superior (acrilamida 3,5\% - bisacrilamida 0,045\%, em tampão Tris/ $\mathrm{HCl}, 6 \mathrm{mM}$, pH6,8; 0,015mM de persulfato de amônia; 0,2\% de TEMED), e imediatamente introduzido o pente para a formação de canaletas para a colocação das amostras, preparadas como descrito no item anterior. As placas foram seladas com agar $2 \%$ às cubas de corrida, foi adicionado 0 tampão de corrida (Tris 0,01M, glicínia 0,083M, pH8,3) aos seus reservatórios. Após a retirada do pente, cada amostra a ser analisada foi colocada na canaleta para a corrida eletroforética, que ocorreu utilizando $20 \mathrm{~mA} /$ placa, durante duas horas.

A coloração foi executada de acordo com HERING et al. (1982). Para a coloração com nitrato de prata, inicialmente cada gel foi transferido para uma solução de etanol a $10 \%$ e ácido acético 0,5\%; após 30 minutos, retirou-se esta solução, sendo acrescentada à solução de nitrato de prata 0,011M. Após mais 30 minutos com agitações periódicas, o gel foi lavado rapidamente por duas vezes com água destilada, em seguida, acrescentou-se à solução reveladora de hidróxido de sódio $(\mathrm{NaOH})$ 0,75M e formaldeído 0,95\%. Após a visualização das bandas, a revelação foi interrompida removendo-se a solução reveladora e acrescentando-se a solução de ácido acético 5\%, por 15 minutos. Para conservar o gel até o momento de fotografar e/ou secar, o gel foi mantido em uma solução de etanol a 10\%.

\subsubsection{Secagem do gel}

Para a secagem do gel, inicialmente desprezou-se a solução de etanol a $10 \%$ na qual os mesmos estavam sendo conservados e adicionou-se a solução de secagem (metanol 65\%, etanol 10\%, glicerol 
0,5\%). Duas folhas de celofane foram embebidas nesta solução. Uma das folhas foi usada para recobrir uma placa de vidro. Em seguida, o gel foi colocado sobre esta placa e sobre o gel, foi colocada a segunda folha de celofane, de forma que esta envolvesse toda a placa de vidro. As folhas de celofane foram bem esticadas e presas sobre a placa de vidro. Após dois dias à temperatura ambiente, com o gel totalmente seco, este foi retirado da placa de vidro.

\subsubsection{Fotografia do gel}

Para fotografar os géis, antes da secagem, utilizou-se câmera Polaroid MP4, com filme Polaroid 667 ou o sistema de foto documentação digital Doc-Print da Vilber Lourmat (DP001-FDC v.99)

\subsubsection{Amostra Padrão}

Em todas as corridas eletroforéticas foi incluída, como amostra padrão, a cepa SiRv-A/SA11, de rotavírus de macaco, cultivada em cultura celular MA104, cujo dsRNA foi extraído conforme descrito acima.

\subsection{Ensaio imunoenzimático para determinação de subgrupo}

Para a caracterização de amostras positivas quanto ao subgrupo, utilizou-se o ensaio imunoenzimático do tipo "duplo sanduíche" (PEREIRA et al., 1983)

Foram utilizados anticorpos monoclonais (MAbs) que reconhecem antígenos de grupo A, subgrupos I (255/60) e subgrupo II (631/9). Estes MAbs foram gentilmente cedidos pelo Dr. Thomas $\mathrm{H}$. Flewett, do East Birmingham Hospital, Birmingham, Inglaterra e foram produzidos pelo Dr. H.B. Greenberg da Universidade de Stanford, Califórnia, EUA (GREENBERG et al., 1983). Além disso, foi usado também o MAb (A4B5) também específico para subgrupo I, fornecido pelo Dr. Ferdinando Liprandi do Instituto Venezuelano de Investigações Científicas (LIPRANDI et al., 1990). Este MAb reconhece a maioria das amostras não I- não II. Os anticorpos monoclonais foram usados como soro 
detector. Como amostras controle dos MAbs foi usada a amostra PoRvA/OSU específica para subgrupo I e A-4B5 e as amostras padrão HuRvA/WA ou HuRv-A/ST3 específicas para o subgrupo II. O teste foi realizado em microplacas de 96 orifícios (Nunc ${ }^{\mathrm{TM}}$-Immuno Plate cat. 442404).

\subsubsection{Sensibilização das microplacas}

As microplacas foram sensibilizadas com $100 \mu \mathrm{l}$ de soro de cabra anti-rotavírus, diluído a 1:10.000 em tampão carbonato - bicarbonato $0,25 \mathrm{M}, \mathrm{pH}$ 9,6. Em seguida, as microplacas foram incubadas por 2 horas a $37^{\circ} \mathrm{C}$ ou por 18 horas a $4^{\circ} \mathrm{C}$.

\subsubsection{Lavagem das microplacas}

Após a incubação, as microplacas foram lavadas por cinco vezes com $200 \mu \mathrm{l}$ de PBS/T (PBS 0,01M, pH 7,4; Tween 20 0,05\%), aguardando-se 2 minutos entre cada lavagem. Esta foi realizada utilizando-se pipeta multicanal e aspiração por vácuo e repetida entre cada uma das etapas deste protocolo.

\subsubsection{Bloqueio}

Após a primeira lavagem, foi feito o bloqueio da reação incubando as microplacas por 2 horas a $37^{\circ} \mathrm{C}$ com $200 \mu$ da solução de Bloqueio (2,5\% de leite desnatado; PBS 0,01M, pH 7,4).

\subsubsection{Adição das amostras}

Em seguida, após a lavagem com descrito anteriormente, foi feita a distribuição de $25 \mu \mathrm{l}$ de cada uma das amostras em 4 orifícios contendo $75 \mu \mathrm{l}$ de diluente PBS/T/BSA/EDTA (PBS 0,01M, pH 7,4; Tween 20 0,05\%; BSA 1\%; EDTA 0,1M), cada orifício correspondendo a um anticorpo monoclonal. À mesma placa, foram adicionados os controles positivos de rotavírus de subgrupo I, subgrupo II, A-4B5 e grupo A, 
indicadas anteriormente. Foram adicionados $75 \mu \mathrm{l}$ de PBS/T/BSA às depressões correspondentes aos controles de conjugado e substrato. As microplacas foram incubadas por 18 horas a $4^{\circ} \mathrm{C}$.

\subsubsection{Adição dos MAbs, soros detectores}

Após a incubação, as placas foram lavadas como descrito anteriormente. Foram adicionados os anticorpos monoclonais específicos para cada subgrupo I, II, A-4B5 e grupo A diluídos, respectivamente, a 1:5.000, 1:10.000, 1:5 e 1:10.000. Os MAbs foram diluídos em PBS/T/BSA e distribuídos $100 \mu \mathrm{l}$ em colunas alternadas das microplacas, inclusive nos orifícios correspondentes aos controles positivos, de conjugado e substrato.

\subsubsection{Adição do soro conjugado e do substrato}

Foram realizados conforme descrito nos itens 4.5 e 4.6 respectivamente. Para esta reação o soro conjugado usado foi IgG de cobaio anti IgG de camundongo, Sigma (A-2554), conjugado a peroxidase.

\subsubsection{Leitura}

A leitura foi feita visualmente e por medida da densidade ótica em leitor espectrofotométrico (Reader Microelisa System, Organon Teknika) com filtro de 492nm. Foi considerada positiva a amostra que apresentou densidade ótica maior ou igual ao dobro da média das densidades óticas obtidas nos orifícios correspondentes ao controle de conjugado.

\subsection{Ensaio imunoenzimático para determinação de sorotipo}

Para a caracterização de amostras positivas quanto ao sorotipo, utilizou-se o ensaio imunoenzimático do tipo "duplo sanduíche" (PEREIRA et al., 1985). 


\subsubsection{Sensibilização das microplacas}

Microplacas com 96 depressões foram sensibilizadas com anticorpos monoclonais específicos para os sorotipos G1, G2, G3 e G4 e Grupo A (Serotec Laboratory, Japão). Os MAbs foram diluídos a 1:5.000, em tampão carbonato - bicarbonato $0,25 \mathrm{M}, \mathrm{pH}$ 9,6. E distribuídos $100 \mu \mathrm{l}$ em colunas alternadas das microplacas correspondendo a cada um dos MAbs específicos para os sorotipos G1, G2, G3 e G4 e grupo A. Em seguida, as microplacas foram incubadas por 2 horas a $37^{\circ} \mathrm{C}$, ou por 18 horas a $4^{\circ} \mathrm{C}$.

\subsubsection{Lavagem das microplacas}

Entre cada uma das etapas, as microplacas foram lavadas por cinco vezes com 200 $\mu$ le PBS/T (PBS 0,01M, pH 7,4; Tween 20 0,05\%), aguardando-se 2 minutos entre cada lavagem. Esta foi realizada utilizando-se pipeta multicanal e aspiração por vácuo.

\subsubsection{Bloqueio}

Para o bloqueio, foram adicionados $250 \mu \mathrm{l}$ de PBS/T/BSA (PBS 0,01M, pH 7,4; Tween 20 0,05\%; BSA 1\%) por orifício e as microplacas foram incubada por 6 horas a $4^{\circ} \mathrm{C}$.

\subsubsection{Adição das amostras}

Após nova lavagem como descrito acima, $25 \mu$ l das amostras foram distribuídas aos orifícios correspondentes contendo $75 \mu$ de diluente PBS/T/BSA (PBS 0,01M, pH 7,4; Tween 20 0,05\%; BSA 1\%). Foram usadas como controles positivos às amostras padrões humanas HuRv-A/Wa ou HuRv-A/RV4 (G1), HuRv-A/DS1 (G2), SiRv-A/SA11 (G3 e grupo A), HuRv-A/ST-3 (G4) as quais também foram adicionados $25 \mu \mathrm{l}$ aos orifícios correspondentes, já contendo $75 \mu \mathrm{l}$ do diluente. Foram adicionados $100 \mu \mathrm{l}$ de PBS/T/BSA aos orifícios correspondentes aos controles de conjugado e substrato. As microplacas foram incubadas por 18 horas a $4^{\circ} \mathrm{C}$. 


\subsubsection{Adição do soro detector, adição do soro conjugado e adição do substrato.}

Foram realizados de acordo com o descrito acima nos itens 4.5., 4.6. e 4.7., respectivamente. Entre cada uma das etapas, as microplacas foram lavadas por cinco vezes como descrito anteriormente.

\subsubsection{Leitura}

A leitura foi feita visualmente e por medida da densidade ótica em leitor espectrofotométrico (Reader Microelisa System, Organon Teknika) com filtro de $492 \mathrm{~nm}$. Foram considerada positiva as amostras que apresentaram densidade ótica maior ou igual ao dobro da média das densidades óticas obtidas nos controles de conjugado. Foi considerada pertencente a um sorotipo a amostra que apresentou como resultado a densidade ótica equivalente à pelo menos o dobro da densidade ótica obtida para os demais sorotipos. Foi considerada mistura de sorotipos quando a densidade ótica obtida para dois ou mais sorotipos foi superior ao dobro da densidade ótica obtida no controle do conjugado e para os demais sorotipos.

\subsection{Caracterização molecular de genótipos $G$ e $P$}

Transcrição reversa seguida de reação em cadeia da polimerase e subseqüente re-amplificação com primers múltiplos ("semi-nested RT-PCR")

A técnica de RT-PCR foi realizada de acordo com os protocolos descritos por DAS et al. 1994; GOUVEA et al. 1990, 1994a e b; GENTSCH et al. 1992 com modificações na etapa de extração do ácido nucléico viral.

Em todas as reações, foram incluídas amostras padrão de cada um dos genótipos, usadas como controles positivos (Tabela 4) e água 
como controle negativo. Para evitar a contaminação das amostras durante a realização da RT-PCR, foram usados quatro laboratórios diferentes, um exclusivo para a extração do dsRNA viral, outro para preparo das etapas da transcrição reversa e primeira amplificação, o terceiro para a transferência do DNA amplificado para a segunda PCR e o quarto para o preparo e corrida do gel de agarose e documentação digital do resultado obtido.

Os diferentes iniciadores (primers) usados para a genotipagem das amostras de rotavírus de encontram-se descritos nas Tabelas 5 e 6, bem como suas respectivas posições de anelamento; seqüências de nucleotídeos; amostra usada como protótipo de genótipo e referencia bibliográfica.

TABELA 5: Seqüência de nucleotídeos dos primers utilizados na caracterização de genótipos $\mathrm{P}$ da proteína VP4, suas respectivas posições de anelamento; amostra usada como protótipo de genótipo e referência bibliográfica.

\begin{tabular}{|c|c|c|c|c|c|}
\hline Primers & Posição & Seqüência (5'- 3') & Amostra & Genótipo P & Referência bibliográfica \\
\hline \multicolumn{6}{|c|}{ COMUNS* } \\
\hline Con3 & $11-32$ & TGGCTTCGCCTATTTATAGACA & HuRV-A/KU & & GENTSCH et al., 1992 \\
\hline Con2 & $868-887$ & ATTTCGGACCATTTATAACC & HuRV-A/KU & & GENTSCH et al., 1992 \\
\hline \multicolumn{6}{|c|}{ HUMANO } \\
\hline 1T.1 & $339-356$ & TCTACTTGGATAACGTGC & HuRV-A/KU & [8] & GENTSCH et al., 1992 \\
\hline $2 \mathrm{~T} .1$ & $474-494$ & CTATTGTTAGAGGTTAGAGTC & HuRV-A/RV5 & {$[4]$} & GENTSCH et al., 1992 \\
\hline 3Т.1 & $259-278$ & TGTTGATTAGTTGGATTCAA & HuRV-A/1076 & {$[6]$} & GENTSCH et al., 1992 \\
\hline $4 \mathrm{~T} .1$ & $385-402$ & TGAGACATGCAATTGGAC & HuRV-A/K8 & [9] & GENTSCH et al., 1992 \\
\hline 5T.1 & $575-594$ & ATCATAGTTAGTAGTCGG & HuRV-A/69M & {$[10]$} & GENTSCH et al., 1992 \\
\hline \multicolumn{6}{|l|}{ ANIMAL } \\
\hline PNCDV & $269-289$ & CGAACGCGGGGGTGGTAGTTG & BoRv-A/NCDV & [1] & GOUVEA et al., 1994 \\
\hline PUK & $336-354$ & GCCAGGTGTCGCATCAGAG & BoRV-A/UK & [5] & GOUVEA et al., 1994 \\
\hline POSU & $389-412$ & CTTTATCGGTGGAGAATACGTCAC & PoRV-A/OSU & [7] & GOUVEA et al., 1994 \\
\hline PGott & $465-487$ & GCTTCAACGTCCTTTAACATCAG & PoRV-A/Gott & {$[6]$} & GOUVEA et al., 1994 \\
\hline PB223 & $574-594$ & GGAACGTATTCTAATCCGGTG & BoRV-A/B223 & [11] & GOUVEA et al., 1994 \\
\hline
\end{tabular}

*Comuns: amplificam todos os genótipos

\subsubsection{Extração do ácido nucléico viral}


A extração do dsRNA viral a partir das suspensões de fezes foi realizada utilizando-se TRIZOL $^{\circledR}$ Reagent (Invitrogen 15596), de acordo com o protocolo descrito pelo fabricante.

Em tubos tipo Eppendorf misturou-se um volume de $300 \mu l$ da suspensão fecal a $20 \%$ e $900 \mu \mathrm{l}$ de TRIZOL $^{\circledR}$. A mistura foi homogeneizada manualmente e incubada a temperatura ambiente durante cinco minutos. Foram adicionados $240 \mu$ l de clorofórmio, seguido de agitação em vortex durante 15 segundos e incubado a temperatura ambiente por 10 minutos.

\subsubsection{Eletroforese em gel de agarose}

As amostras amplificadas foram submetidas à eletroforese em gel de agarose a 1,5\% em tampão Tris/borato/EDTA - TBE (Tris 0,089M; ácido bórico 0,0089M; EDTA 0,002M pH 8,0) contendo $4 \mu$ l brometo de etídio a $10 \mathrm{mg} / \mathrm{ml}$ (Invitrogen cat. 15585) para cada 50ml de tampão. O gel foi preparado em cubas de eletroforese horizontal. Um volume de $10 \mu \mathrm{l}$ do produto da $2^{\mathrm{a}}$ amplificação foi misturado com $1 \mu$ da solução de corante (azul de bromofenol 0,25\%; xileno cianol 0,25\%; glicerol 30\% em água destilada) e aplicado a cada canaleta correspondente. Nas primeiras e últimas canaletas foi aplicado $4 \mu \mathrm{l}$ o padrão de peso molecular (100pb DNA Ladder, Invitrogen cat. $156281 \mu \mathrm{g} / \mu \mathrm{l})$.

A corrida em cuba horizontal de eletroforese foi realizada utilizando como tampão de corrida TBE 0,5X (Tris 0,089M; ácido bórico 0,0089M; EDTA 0,002M pH 8,0) e a voltagem de 100 volts. Após aproximadamente uma hora e meia de corrida, a análise do gel foi realizada através da visualização em transiluminador de luz ultravioleta (UV) e o gel foi documentado em fotografia digitas utilizando o equipamento Doc-Print da Vilber Lourmat (DP001-FDC v.99). A imagem salva foi impressa e analisada. 
TABELA 6: Seqüência de nucleotídeos dos primers utilizados na caracterização do genótipo $\mathrm{G}$ da proteína VP7, suas respectivas posições de anelamento; amostra usada como protótipo de genótipo e referencia bibliográfica.

\begin{tabular}{|c|c|c|c|c|c|}
\hline Primer & Posição & Seqüência (5'- 3') & Amostra & Genótipo G & $\begin{array}{l}\text { Referência } \\
\text { bibliográfica }\end{array}$ \\
\hline \multicolumn{6}{|l|}{ COMUNS* } \\
\hline 9Con1 & $37-56$ & TAGCTCCTTTTAATGTATGG & HuRV-A/Wa & & DAS et al., 1994 \\
\hline 9Con2 & $941-922$ & GTATAAAATACTTGCCACCA & HuRV-A/Wa & & DAS et al., 1994 \\
\hline Beg9 & $1-28$ & \multicolumn{2}{|c|}{ GGCTTTAAAAGAGAGAATTTCCGTCTGG HuRV-A/Wa } & & GOUVEA et al., 1990 \\
\hline sBeg9 & $1-21$ & GGCTTTAAAAGAGAGAATTTC & HuRV-A/Wa & & GOUVEA et al., 1994b \\
\hline RVG9 & $1062-1044$ & GGTCACATCATACAATTCT & SiRV-A/Sa11 & & GOUVEA et al., 1990 \\
\hline EndUK & $1062-1039$ & GGTCACATCATACAACTCTAATCT & BoRV-A/UK & & GOUVEA et al., 1994b \\
\hline EndCRW8 & 1062-1039 & GGTCACATCTTACAGCTTTAACCT & PoRV-A/CRW-8 & & GOUVEA et al., 1994b \\
\hline End9 & $1062-1036$ & GGTCACATCATACAATTCTAATCTAAG & SiRV-A/Sa11 & & GOUVEA et al., 1990. \\
\hline \multicolumn{6}{|l|}{ HUMANOS } \\
\hline 9T1-1 & $195-176$ & TCTTGTCAAAGCAAATAATG & HuRV-A/Wa & G1 & DAS et al., 1994 \\
\hline 9T1-2 & $281-262$ & GTTAGAAATGATTCTCCACT & HuRV-A/S2 & G2 & DAS et al., 1994 \\
\hline $9 \mathrm{~T}-3 \mathrm{P}$ & $503-484$ & GTCCAGTTGCAG TGTAG C & HuRV-A/1076 & G3 & DAS et al., 1994 \\
\hline 9T-4 & $440-423$ & GGGTCGATGGAA AATTCT & HuRV-A/ST3 & G4 & DAS et al., 1994 \\
\hline $9 \mathrm{~T}-9 \mathrm{~B}$ & $147-131$ & TATAAAGTCCATTGCAC & HuRV-A/116E & G9 & DAS et al., 1994 \\
\hline aBT1 & $314-335$ & CAAGTACTCAAATCAATGATGG & HuRV-A/Wa & G1 & GOUVEA et al., 1990 \\
\hline aCT2 & $411-435$ & CAATGATATTAACACATTTTCTGTG & HuRV-A/DS1 & G2 & GOUVEA et al., 1990 \\
\hline aDT4 & $480-498$ & CGTTTCTGGTGAGGAGTTG & HuRV-A/ST3 & G4 & GOUVEA et al., 1990 \\
\hline aET3 & $689-709$ & CGTTTGAAGAAGTTGCAACAG & HuRV-A/P & G3 & GOUVEA et al., 1990 \\
\hline aFT9 & $757-776$ & CTAGATGTAACTACAACTAC & HuRV-A/WI61 & G9 & GOUVEA et al., 1990 \\
\hline \multicolumn{6}{|l|}{ ANIMAL } \\
\hline FT5 & $779-760$ & CATGTACTCGTTGTTACGTC & PoRV-A/OSU & G5 & GOUVEA et al,1994b \\
\hline DT6 & $499-481$ & CTAGTTCCTGTGTAGAATC & BoRV-A/UK & G6 & GOUVEA et al,1994b \\
\hline HT8 & $273-256$ & CGGTTCCGGATTAGACAC & HuRV-A/B37 & G8 & GOUVEA et al,1994b \\
\hline ET10 & $714-697$ & TTCAGCCGTTGCGACTTC & BoRV-A/B223 & G10 & GOUVEA et al,1994b \\
\hline BT11 & $366-316$ & GTCATCAGCAATCTGAGTTGC & PoRV-A/YM & G11 & GOUVEA et al,1994b \\
\hline
\end{tabular}

*Comum: amplifica todos os genótipos 


\subsubsection{Interpretação dos resultados}

O genótipo de cada amostra testada foi definido pelos diferentes tamanhos dos fragmentos obtidos (Tabela 8 e 9). O tamanho de cada segmento foi estabelecido por comparação com fragmentos obtidos nas amostras padrão e do padrão de peso molecular. Desta forma, o genótipo foi considerado definido quando segmento amplificado apresentou o mesmo tamanho encontrado nas amostras padrões.

As amostras que amplificaram segmentos de tamanhos diferentes e/ou com características de dois ou mais genótipos foram testadas novamente em reação contendo um único primer específico de cada genótipo, para descartar qualquer tipo de contaminação e/ou revelar a presença de mais de um genótipo ocorrendo ao mesmo tempo em uma amostra.

Tabela 8: Tamanho dos segmentos produzidos pela "semi nested RT-PCR" para cada um dos genótipos $G$ de rotavírus testados e seus respectivos primers.

\begin{tabular}{llllll}
\hline Primer & Genótipo & $\begin{array}{l}\text { Tamanho do } \\
\text { segmento (pb) }\end{array}$ & Primer & Genótipo segmento (pb) \\
\hline \hline
\end{tabular}


Tabela 9: Tamanho dos segmentos produzidos pela "semi nested RT-PCR" para cada um dos genótipos $P$ de rotavírus testados e seus respectivos primers.

\begin{tabular}{llllll}
\hline & \multicolumn{2}{c}{ Tamanho do } & \multicolumn{1}{c}{ Tamanho do } \\
Primer & Genótipo & segmento (pb) & Primer & Genótipo segmento (pb) \\
\hline \hline
\end{tabular}

\subsection{Sequenciamento genômico}

Foram submetidas ao sequenciamento de nucleotídeos do segmento correspondente às proteínas VP4, amostras de rotavírus que apresentara na caracterização através da técnica de "semi-nested - RTPCR" um genótipo pouco usual.

Para o sequenciamento, foi utilizado o produto, visível em gel de agarose, da $1^{a}$ amplificação de cada amostra. Este segmento foi obtido por RT-PCR, com os primers con2 e con3, específicos para o gene da proteína VP4 que se desejava analisar. Estes primers foram descritos, anteriormente na Tabela 5.

\subsubsection{Extração do DNA para o sequenciamento}

A extração do DNA resultante da reação de RT-PCR se faz necessária para a remoção de reagentes que possam interferir na reação de sequenciamento.

O produto da $1^{\mathrm{a}}$ amplificação visível no gel de agarose foi submetido à purificação através do kit comercial QIAquick ${ }^{\mathrm{TM}} P C R$ Purification (Qiagen cat. 28104) usado para a purificação direta do produto de PCR, seguindo o protocolo descrito pelo fabricante.

Após a purificação, os $50 \mu \mathrm{l}$ de solução de DNA obtida, foram estocados $\mathrm{a}-20^{\circ} \mathrm{C}$ até o momento da reação de sequenciamento. 
A concentração do DNA resultante do processo de purificação para cada amostra foi determinada através de comparação com um padrão de peso molecular (Low DNA Mass Ladder, Invitrogen cat. 10068). Foram aplicados em gel de agarose a $1,5 \%$, contendo $1 \mu \mathrm{g} / \mathrm{mL}$ de brometo de etídio, $4 \mu \mathrm{l}$ do DNA purificado, e de $4 \mu \mathrm{l}$ do padrão de peso molecular (Low DNA Mass Ladder, Invitrogen). Após a eletroforese com tampão TBE 0,5X, o gel foi visualizado em transiluminador com luz ultravioleta e fotografado para posterior análise.

Os produtos amplificados foram analisados pela comparação da intensidade das bandas da amostra com as bandas do padrão de peso molecular Low DNA Mass Ladder, que correspondem a uma quantidade definida de DNA, medida em nanogramas (ng) e fornecida pelo fabricante. Dessa maneira foi possível definir a concentração de DNA de cada amostra a ser usado na reação de sequenciamento.

A quantidade de DNA recomendada pelo fabricante do kit de sequenciamento para produtos obtidos a partir de reação de PCR, varia de 30 até 90 ng. Para as amostras humanas em estudo, foram utilizados de 40 a 60 ng, dependendo da amostra.

\subsubsection{Reação de sequenciamento}

O DNA purificado foi submetido à reação cíclica de sequenciamento, utilizando o kit comercial BigDye Terminator Cycle Sequencing Ready Reaction V1.1 (Applied Biosystems cat.4303152). Inicialmente foi preparada a mistura dos reagentes composta de Big Dye

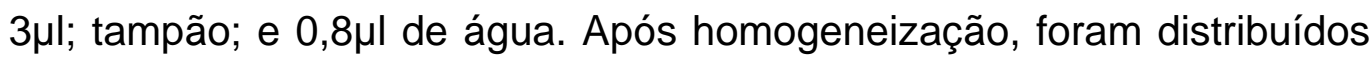
$8,8 \mu \mathrm{l}$ em cada orifício da placa de sequenciamento (Abgene, ThermoFast $96^{\circledR}$ AB-0600). A seguir foram adicionados 3,2 nMoles de cada primer específico por orifício, correspondente a cada reação. Na etapa seguinte, a placa foi levada para outra sala, onde as amostras de DNA purificadas estavam armazenadas. Foi adicionada 'a reação de 40 a 60 ng do DNA purificado. 
As extensões enzimáticas foram realizadas com os seguintes tempos e temperaturas: um ciclo de desnaturação do DNA de $96^{\circ} \mathrm{C}$ por 2 minutos, seguidos de 30 ciclos de $96^{\circ} \mathrm{C}$ por 10 segundos para uma segunda desnaturação do DNA, $50^{\circ} \mathrm{C}$ por 10 segundos para 0 anelamentodos primers e $60^{\circ} \mathrm{C}$ durante 4 minutos para a extensão dos produtos amplificados. Ao final dos 30 ciclos, após uma extensão de 7 minutos a $72^{\circ} \mathrm{C}$, as amostras foram mantidas a $4^{\circ} \mathrm{C}$ por até 24 horas. Este processo foi realizado em termociclador (Perkin Elmer Gene Amp. PCR System 9600).

\subsubsection{Purificação do produto do sequenciamento e análise dos resultados}

Após a reação de sequenciamento, o produto do sequenciamento foi purificado utilizando o kit DyeEXTM spin (Qiagen cat. 63206) de acordo com o protocolo descrito pelo fabricante. Na etapa final os produtos obtidos foram aplicados no analisador automático de DNA modelo Hitach ABI-3130 (Genetic Analyzer - Applied Biosystems) seguindo as condições descritas por Carnieli, et al. (2006) e os resultados gravados em disquete para posterior análise.

Os dados obtidos foram analisados através do programa Cromas, Bioedt e Mega e as seqüências resultantes foram comparadas com seqüências existentes no GenBank, através dos programas Blast e Entrez, por meio da Internet (Carnieli, et al., 2006). As árvores filogenéticas foram construídas para confirmar o genótipo observado na reação de "semi-nested - RT-PCR", através da comparação com as seqüências obtidas no GenBank, das amostras padrão deste genótipo com o processamento 10000 bootstraps. Para serem considerados de um genótipo específico, as seqüências de nucleotídeo obtidas tiveram que apresentar identidades iguais ou superiores a $88 \% \mathrm{com}$ as seqüências padrão encontradas no GenBank, (Tabela 10) valores adotados por Caruzo, 2006. 
Tabela 10: Padrões usados para comparação da seqüência de DNA, seus respectivos genótipos e número de depósito no GenBanck.

\begin{tabular}{lll}
\hline GENÓTIPO & AMOSTRA & Número GenBanck \\
\hline $\mathrm{P}[1]$ & BoRV-A/NCDV & AB119636.1 \\
$\mathrm{P}[2]$ & SiRV-A/SA11 & DQ841262.1 \\
$\mathrm{P}[3]$ & HuRV-A/HCR13 & L19712.1 \\
$\mathrm{P}[4]$ & HuRV-A/RV5 & M32559.1 \\
$\mathrm{P}[5]$ & BoRV-A/UK & M63267.1 \\
$\mathrm{P}[6]$ & HuRV-A/1076 & M88480.1 \\
$\mathrm{P}[7]$ & PoRV-A/YM & M63231.1 \\
$\mathrm{P}[8]$ & HuRV-A/WA & L34161.1 \\
$\mathrm{P}[8]$ & HuRV-A/Ku & M21014.1 \\
$\mathrm{P}[9]$ & HuRV-A/K8 & D90260.1 \\
$\mathrm{P}[10]$ & HuRV-A/69M & |M60600.1 \\
$\mathrm{P}[11]$ & HuRV-A/116E & L07934.1 \\
$\mathrm{P}[12]$ & EqRV-A/H2 & D13397.1 \\
$\mathrm{P}[13]$ & Po/MDR-13 & L07886.1 \\
$\mathrm{P}[14]$ & HuRV-A/Mc35 & D14032.1 \\
$\mathrm{P}[15]$ & OvRV-A/Lp14 & L11599.1 \\
$\mathrm{P}[16]$ & MuRV-A/EDIM & AF039219.2 \\
$\mathrm{P}[17]$ & BoRV-A/993 83 & D16352.1 \\
$\mathrm{P}[18]$ & EqRV-A/L338 & D13399.1 \\
$\mathrm{P}[19]$ & HuRV-A/Mc345 & D38054.1 \\
$\mathrm{P}[20]$ & MuRV-A/EHP & U08424.1 \\
$\mathrm{P}[24]$ & SiRV-A/TUCH & AY596189.1 \\
$\mathrm{P}[21]$ & BoRV-A/Hg18 & AF237665.1 \\
$\mathrm{P}[23]$ & PoRV-A/134/O4-15 & DQ061053.1 \\
$\mathrm{P}[25]$ & HuRV-A/Dhaka & AY773004.2 \\
$\mathrm{P}[26]$ & PoRV-A/34461-4 & AY768809.1 \\
$\mathrm{P}[27]$ & PoRV-A/344-04-1 & DQ242615.1 \\
\hline & & \\
& &
\end{tabular}



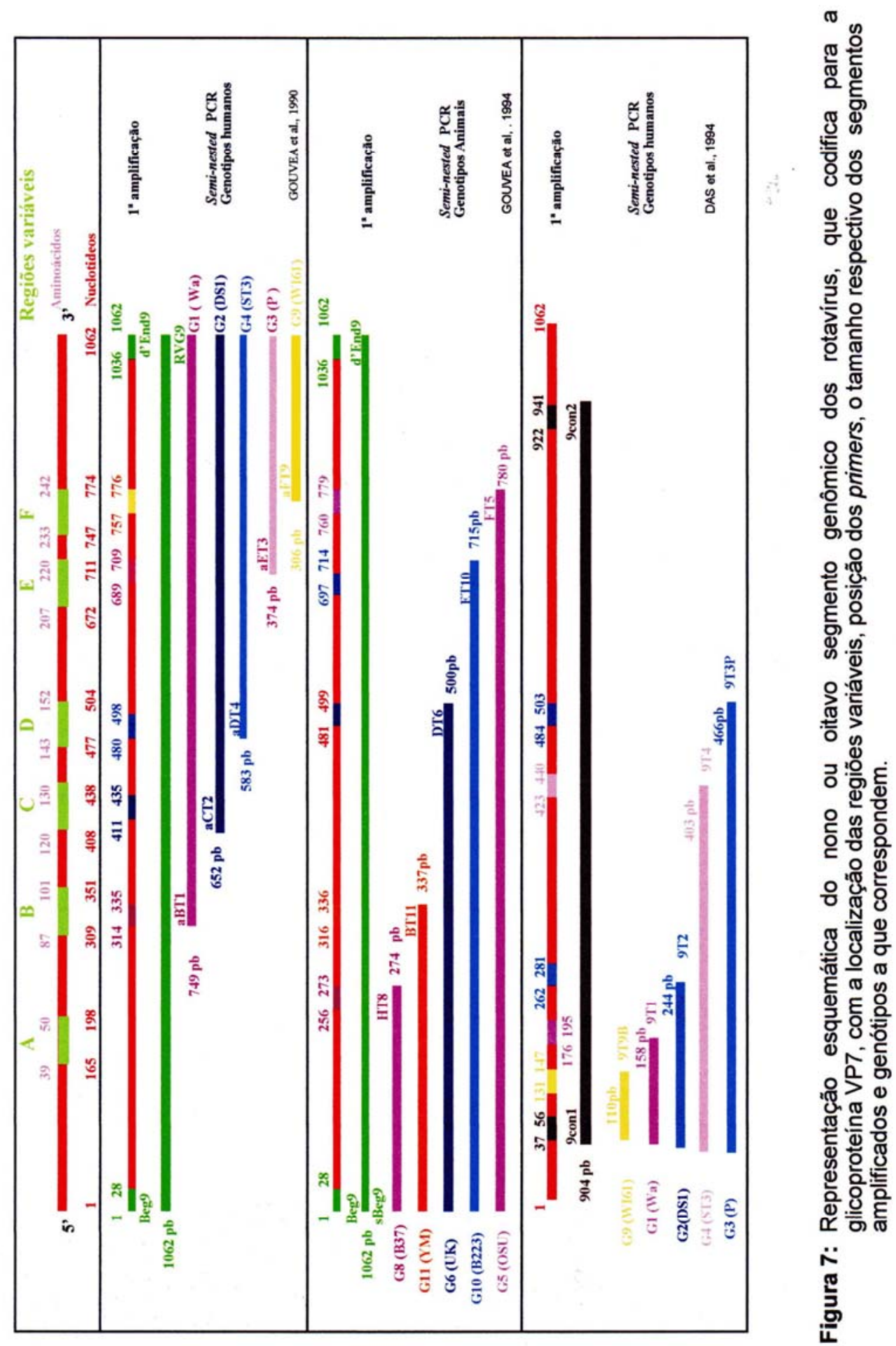

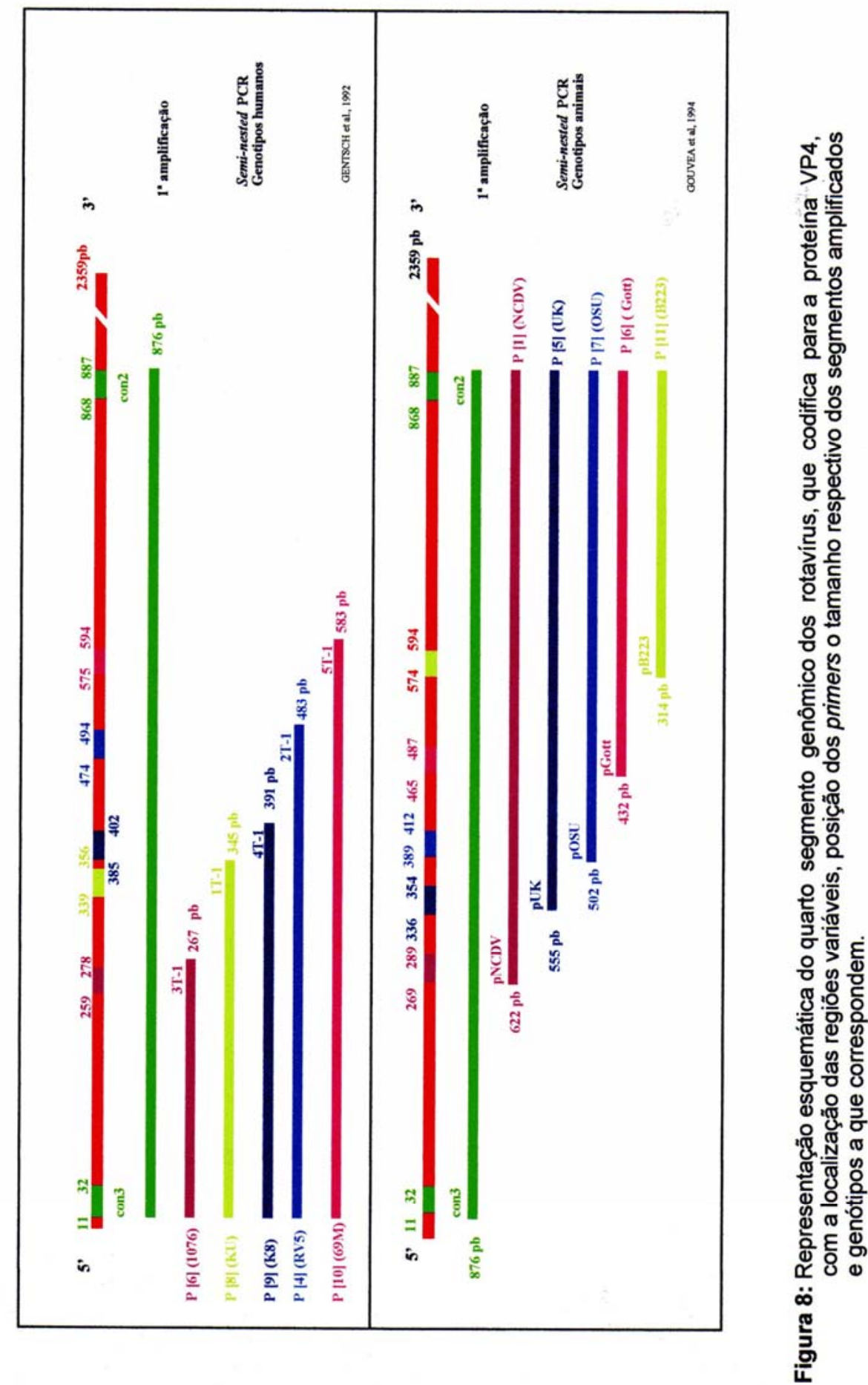


\section{RESULTADOS}

\subsection{TRIAGEM DAS AMOSTRAS}

No total, 214 amostras foram caracterizadas como positivas para rotavírus, através da técnica de ensaio imunoenzimático para rotavírus e adenovírus. Entre as 187 amostras de fezes coletadas no Hospital Universitário no período de 1994 a 1996, foram identificadas 54 (28,9\%) amostras positivas para rotavírus todas em crianças com diarréia e 5 (2,7\%) amostras positivas para adenovírus. Entre as 163 amostras de fezes positivas para rotavírus e coletadas pelo laboratório de análises clínicas particular, no período de janeiro a dezembro de 2000, foram identificadas 160 (98,2\%) amostras positivas para rotavírus através da técnica de EIERA/Fiocruz.

Considerando as 187 amostras coletadas nos anos de 1994 a 1996, 111 amostras possuíam informações referentes à idade das crianças. A porcentagem mais elevada de amostras positivas para rotavírus foi encontrada entre as crianças com idade entre sete e 12 meses $(37,1 \%)$. Nas crianças de zero a seis meses de idade foram identificadas $24,5 \%$ de amostras positivas para rotavírus (Tabela 11), sendo que todas as amostras positivas foram identificadas em crianças com quadro clinico de gastroenterite.

Tabela 11: Distribuição das amostras positivas para rotavírus de acordo com a faixa etária das crianças em São Paulo, Brasil no período de março de 1994 a fevereiro de 1996.

\begin{tabular}{cccc}
\hline Faixa & \multicolumn{3}{c}{ Número de casos } \\
\cline { 2 - 4 } etária (Meses) & Positivo & Total & $\%$ \\
\hline $\mathbf{0 - 6}$ & 13 & 53 & 24,5 \\
$\mathbf{7 - 1 2}$ & 13 & 35 & 37,1 \\
$\mathbf{1 3 - 2 4}$ & 5 & 17 & 29,4 \\
$\mathbf{2 5 - 6 0}$ & 1 & 6 & 16,7 \\
& 1 & 111 & 28,8 \\
\hline
\end{tabular}

Entre as 160 amostras positivas coletadas pelo laboratório particular durante o ano de 2000, em crianças com idade entre sete e 12 meses foram 
identificadas 61 (37\%) do total de amostras. Em seguida, as faixas etárias com maior número de positivos foram de crianças com idades entre 13 e 24 meses, que representaram um total de $41(26,0 \%)$ amostras positivas para rotavírus. Em crianças de 25 a 60 meses foram identificadas 35 amostras positivas para rotavírus, o que representou $22 \%$ das amostras estudadas neste período. Seis amostras de crianças com idade entre zero a seis meses foram positivas, correspondendo a $4 \%$ do total coletado. Além disso, foram identificadas 14 (9\%) amostras positivas em pacientes com idade entre cinco e 60 anos de idade. $\mathrm{E}$ três amostras foram identificadas em pacientes com mais de 60 anos de idade representando $2 \%$ do total das amostras coletadas no período (Figura 9).

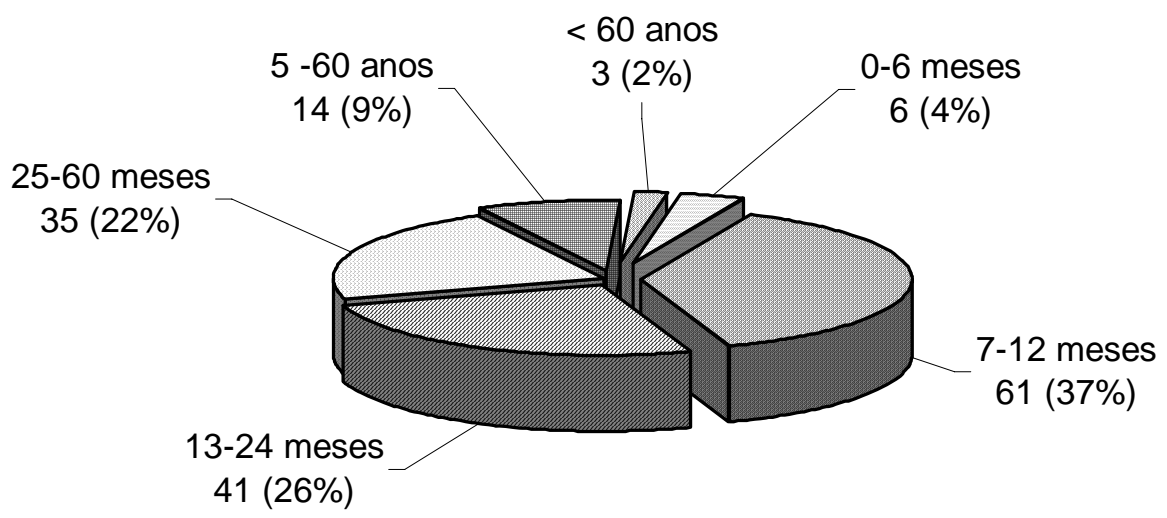

Figura 9: Distribuição das amostras positivas para rotavírus de acordo com a faixa etária dos pacientes em São Paulo, Brasil no período de janeiro a dezembro de 2000.

Tabela 12: Comparação da porcentagem de amostras positivas identificadas por faixa etária das crianças de zero a cinco anos de idade, no dois grupos de amostras estudadas em São Paulo, Brasil nos períodos de março de 1994 a fevereiro de 1996 e fevereiro a outubro de 2000.

\begin{tabular}{ccc}
\hline $\begin{array}{c}\text { Faixa etária } \\
\text { (Meses) }\end{array}$ & \multicolumn{2}{c}{ Porcentagem de amostras positiva } \\
\cline { 2 - 3 } & HU & Laboratório Particular \\
\hline $\mathbf{0 - 6}$ & 40,6 & 4,1 \\
$\mathbf{7 - 1 2}$ & 40,6 & 42,7 \\
$\mathbf{1 3 - 2 4}$ & 15,7 & 28,7 \\
$\mathbf{2 5}-60$ & 3,1 & 24,5 \\
& 100 & 100 \\
\hline
\end{tabular}


Considerando as 187 amostras coletadas nos anos de 1994 a 1996, 156 amostras possuíam informações referentes à data da coleta. Nos dois grupos de amostras estudadas foi possível observar que no verão, entre os meses de dezembro a fevereiro, ocorreu uma diminuição do número de amostras positivas para rotavírus (Figuras 10 e 11). Fica claro também o aumento no número de amostras positivas para rotavírus nos meses de inverno entre maio a agosto nos dois conjuntos de amostras (Figuras 10 e 11).

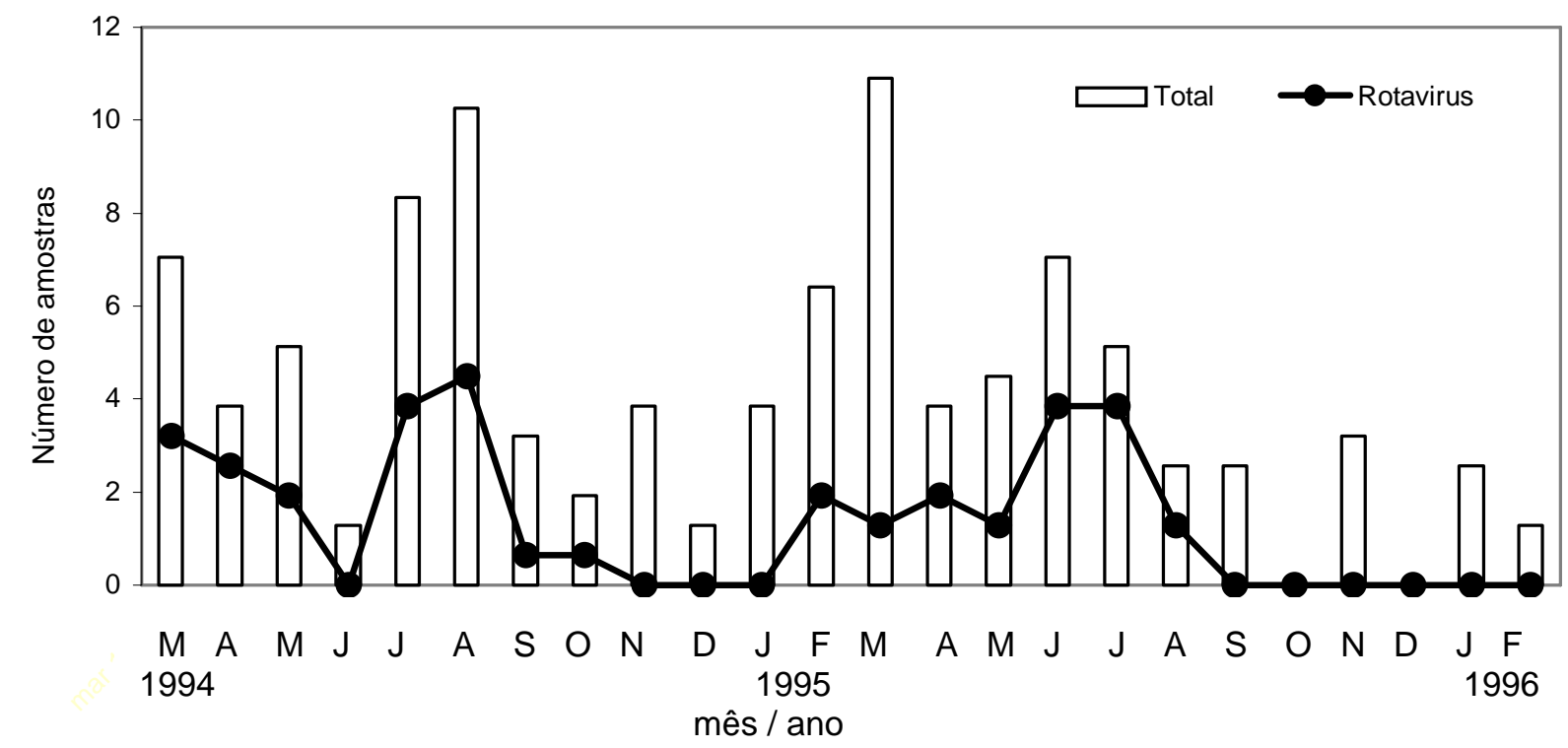

Figura 10: Distribuição sazonal e número de amostras positivas identificadas nas amostras coletadas em São Paulo, Brasil no período março de 1994 a fevereiro de 1996.

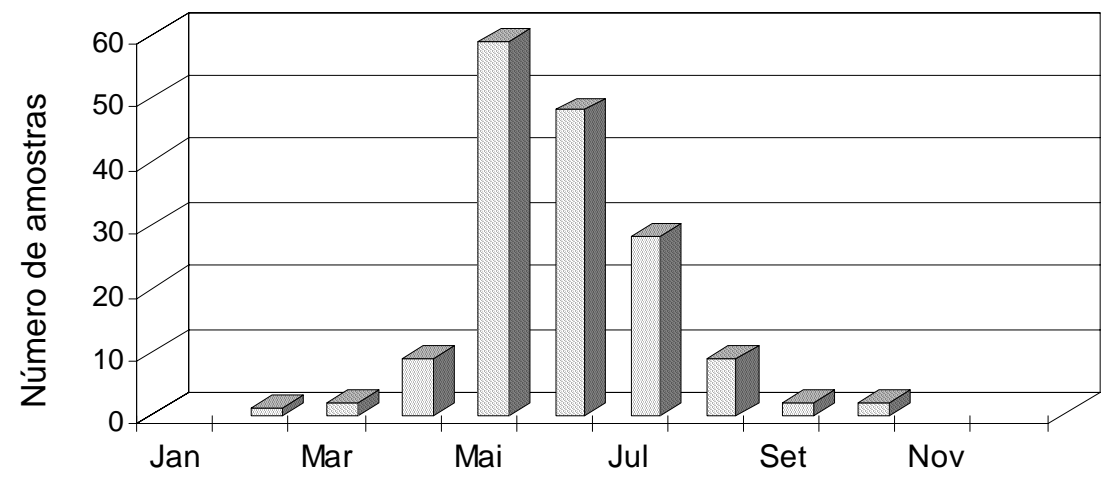

Figura 11: Número de amostras positivas identificadas de fevereiro a outubro em São Paulo, Brasil no período de janeiro a dezembro de 2000. 


\subsection{ANÁLISE DO PERFIL ELETROFORÉTICO}

As 187 amostras coletadas no período de 1994 a 1996 foram analisadas através da técnica de eletroforese em gel de poliacrilamida (EGPA) sendo identificado o perfil eletroforético característico dos rotavírus do grupo A em 50 $(92,6 \%)$ amostras.

Entre as amostras positivas por esta técnica foram caracterizados quatro tipos diferentes de perfis eletroforéticos "longo", encontrados em 24 amostras (48,4\%). O perfil eletroforético "curto" foi identificado em $17(34,0 \%)$ amostras. Nove amostras $(18,0 \%)$ foram caracterizadas como um perfil eletroforético não usual no qual é observado que os segmentos 10 e 11 migram de maneira mais próxima entre eles. (Tabela 13, Figura 12). Três amostras apresentaram mais de 11 segmentos do dsRNA, sugerindo a presença de infecções múltiplas, com mais de uma cepa de rotavírus. Nos três casos, o perfil eletroforético observado foi do tipo "longo" (Figura 12).

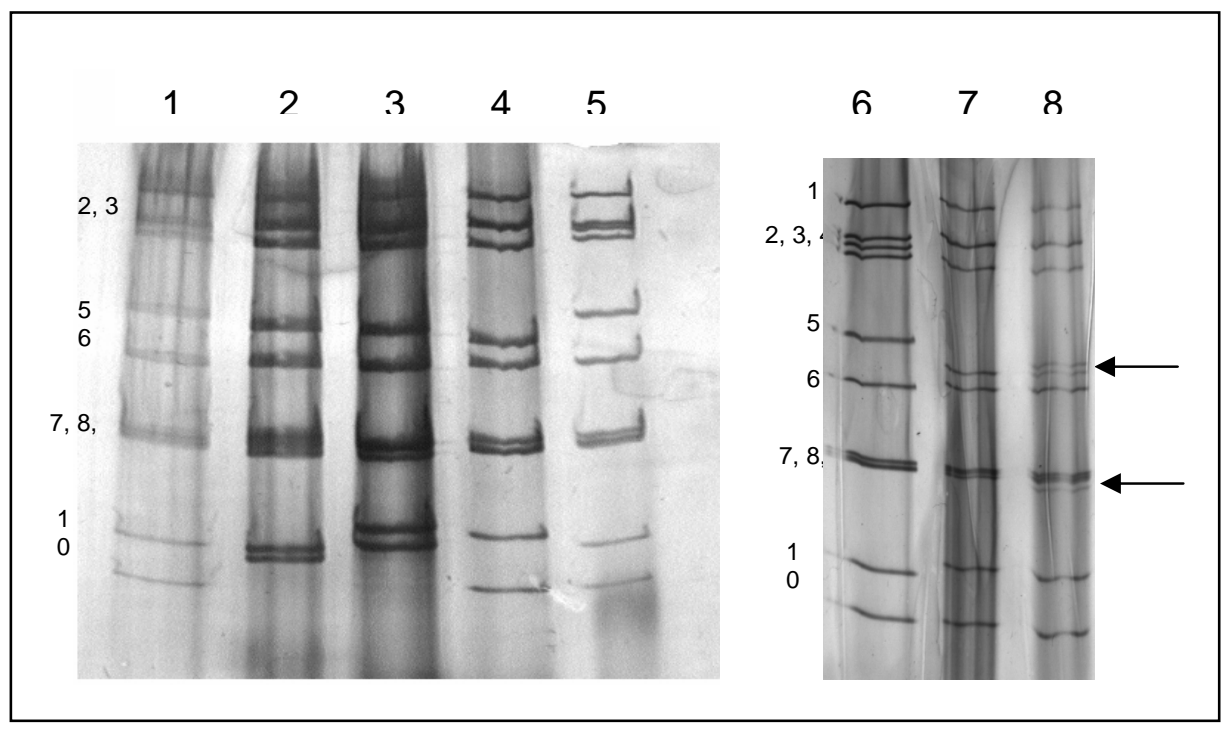

Figura 12: Eletroforese em gel de Poliacrilamida de amostras representativas dos rotavírus identificados em São Paulo no período estudado de 1994 a 1996. Canaletas 1, 5 e 6: controle positivo (SiRV-A/SA11); canaleta 2: amostra HuRV-A/ICB1375, padrão incomum; canaleta 3: amostra HuRV-A/ICB410, padrão "curto"; canaleta 4, amostra HuRV-A/ICB1410, padrão "longo"; canaleta 7 amostra HuRV-A/ICB1340 padrão "longo"; canaleta 8 amostra HuRV-A/ICB1343 padrão "longo" com mistura de eletroferótipo, segmentos extras indicados. 
Entre as 160 amostras coletadas no ano de 2000, 28 amostras positivas para rotavírus foram analisadas através da técnica de EGPA, sendo que todas apresentaram perfil eletroforético do tipo "longo", com variações na migração dos segmentos 2, 3 e 4, 5 e 6 e/ou 7, 8 e 9, sendo identificados cinco tipos diferentes de migração denominados de L1 a L5. Estes cinco de perfis são apresentados na Figura 13.

Tabela 13: Subgrupo, sorotipo e perfil eletroforético obtidos na caracterização das 54 amostras de rotavírus obtidas em São Paulo, no período de março de 1994 a fevereiro de 1996.

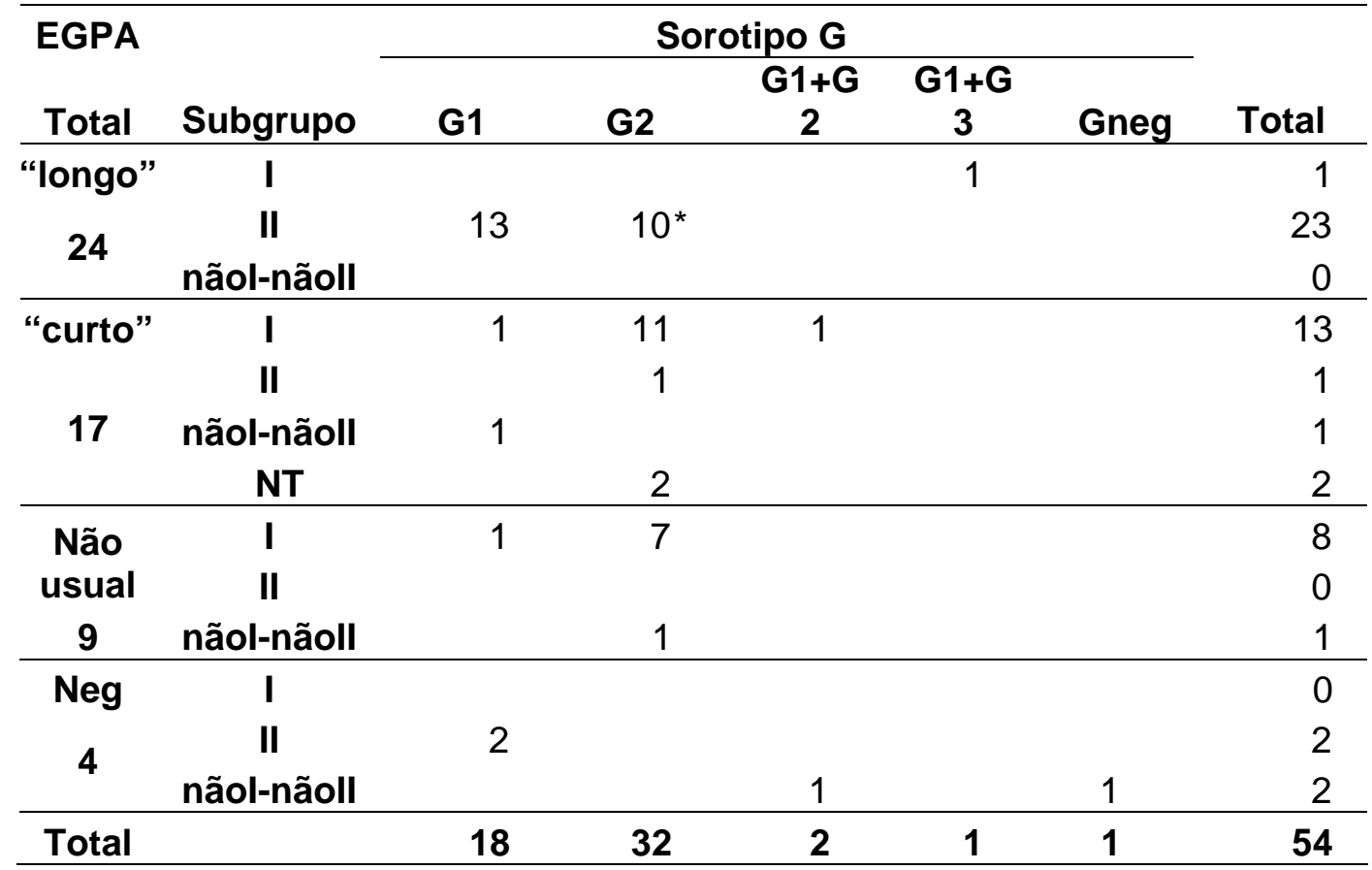

Todas as amostras negativas para rotavírus através da técnica de EIERA, foram analisadas por EGPA, e nenhuma delas apresentou perfil eletroforético semelhante a rotavírus de outros grupos não-A. 


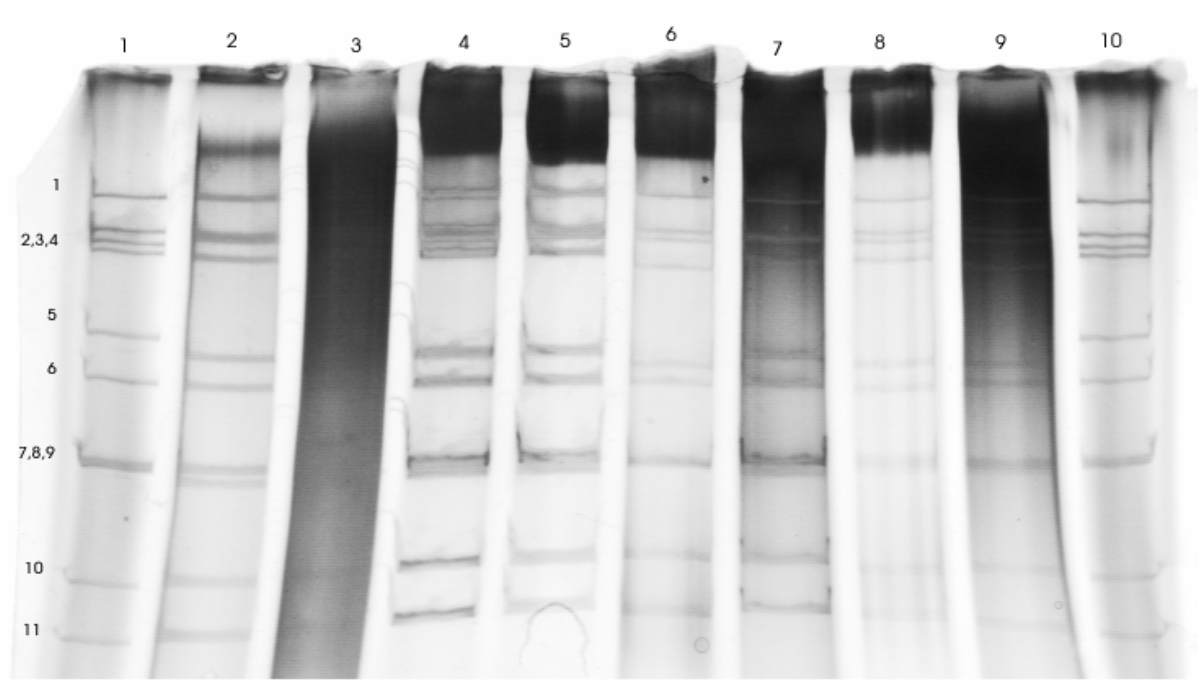

Figura 13: Eletroforese em gel de poliacrilamida de amostras representativas dos rotavírus identificados em São Paulo no ano de 2000. Canaletas 1 e 10: controle positivo (SiRV-A/SA11). Perfil L1: canaletas 2 (HuRv/ICB3325); canaletas 3 (HuRV-A/ICB3332). Perfil L2: canaletas 4 (HuRv/ICB3337); canaletas 5 (HuRV-A/ ICB3371). Perfil L3: canaletas 6 (HuRV-A/ICB3368). Perfil L4: canaleta 7 (HuRV-A/ICB3374). Perfil L5 canaleta 8 (HuRVA/ICB3329); canaleta 9 amostra (HuRV-A/ICB337).

\subsection{CARACTERIZAÇÃO SOROLÓGICA DE SUBGRUPO}

Com relação caracterização de subgrupo (SG), apenas as amostras coletadas no período de 1994 a 1996 foram analisadas, 52 amostras foram caracterizadas, tendo sido identificadas 26 amostras (50\%) do subgrupo II e 22 $(42,3 \%)$ do subgrupo I.

Além disso, quatro amostras testadas por esta técnica reagiram com o anticorpo monoclonal de grupo $A$, mas não reagiram com nenhum dos anticorpos monoclonais específicos de subgrupo, sendo caracterizadas como subgrupo não I não II. Duas amostras não foram analisadas por falta de material fecal.

Entre as 26 amostras caracterizadas como subgrupo II, 20 apresentaram perfil eletroforético "longo". Três apresentaram perfis que sugerem infecções mistas com mais de um perfil eletroforético "longo". Uma amostra apresentou um perfil eletroforético do tipo "curto" e duas não foram caracterizadas por EGPA (Tabela 13). 
Entre as amostras caracterizadas como subgrupo I, uma amostra apresentou perfil eletroforético do tipo "longo"; 13 amostras apresentaram um perfil eletroforético "curto"; oito amostras apresentaram o perfil eletroforético não usual (Tabela 13).

Quatro amostras foram caracterizadas como SG não I - não II, uma com perfil eletroforético não usual, duas com perfil "curto" e duas foram negativas pela técnica de EGPA.

\subsection{CARACTERIZAÇÃO SOROLÓGICA DE SOROTIPO G}

Entre as 54 amostras positivas para rotavírus, coletadas no período de 1994 a 1996, 53 foram caracterizadas quanto ao sorotipo $G$ através de ensaio imunoenzimático com o uso de anticorpos monoclonais específicos para os sorotipos G1 a G4 (Tabela 13).

O sorotipo G2 foi identificado como o único sorotipo presente em 32 $(59,3 \%)$ amostras. Duas amostras reagiram com os monoclonais específicos para os sorotipos G1 e G2 simultaneamente. O sorotipo G1 foi identificado em $18(33,3 \%)$ amostras como único sorotipo presente. Além disso, três amostras apresentaram combinações do sorotipo G1 com outros sorotipos, sendo duas amostras, descritas acima, combinadas com o sorotipo G2 e uma combinada com o sorotipo G3 (Tabela 13 ). Em relação à caracterização sorológica de sorotipos G, apenas uma amostra não reagiu com nenhum dos anticorpos específicos para os tipos $\mathrm{G} 1$ a $\mathrm{G} 4$, tendo reagido apenas com o monoclonal específico para o grupo A. Esta amostra foi caracterizada através da técnica de RT-PCR como sendo do genótipo G2G5.

Os sorotipos G1 e G2 foram identificados tanto em amostras coletadas em 1994 como em 1995. O sorotipo G2 ocorreu em uma maior porcentagem de amostras (20/27, 74\%) durante o ano de 1994 enquanto que em 1995 uma menor porcentagem de amostras (10/24 41,6\%) ocorrendo uma mudança do sorotipo predominante (Figura 14). 


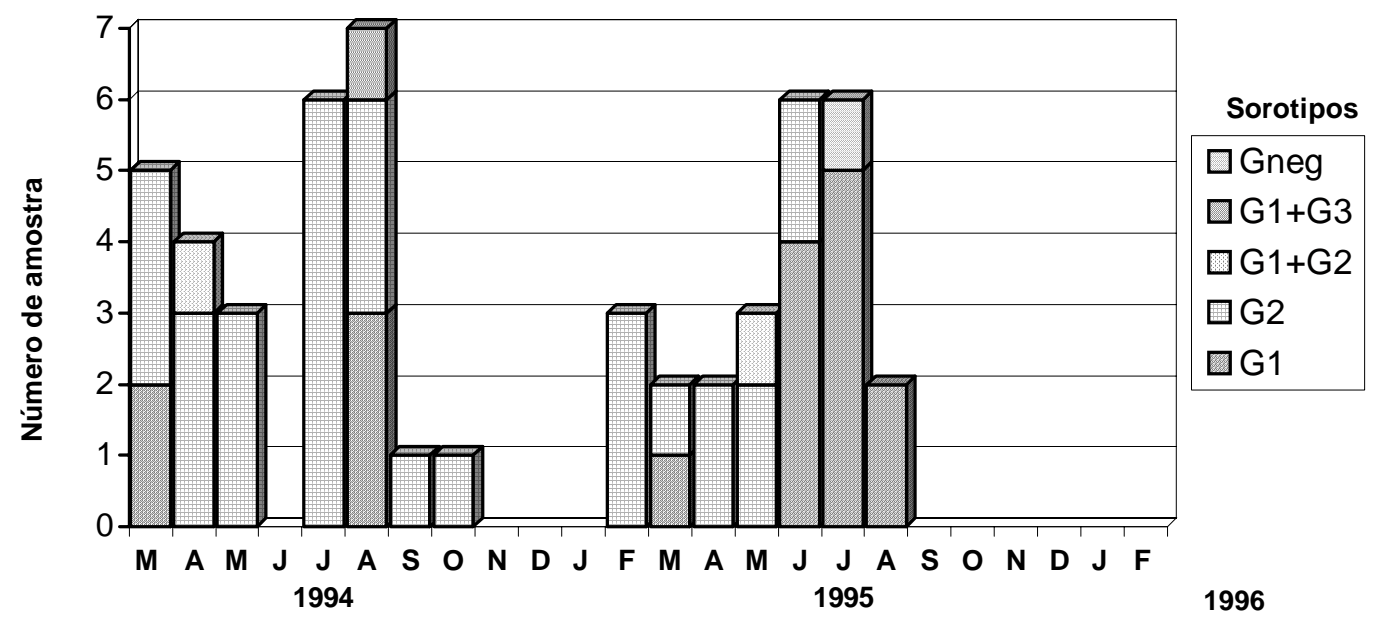

Figura 14: Distribuição mensal dos sorotipos $G$ identificados entre as amostras positivas para rotavírus coletadas em São Paulo, no período março de 1994 a fevereiro de 1996.

\subsection{CARACTERIZAÇÃO MOLECULAR DE GENÓTIPOS G E P}

\subsubsection{GENÓTIPOS G}

No total, 214 amostras foram analisadas através da técnica de seminested RT-PCR, utilizando primers específicos para a proteína VP7, sendo que $210(98,1 \%)$ amostras foram caracterizadas com relação ao genótipo G.

Entre as amostras coletadas no período de março de 1994 a março de 1996, 54 amostras foram submetidas à caracterização por semi-nested RT-PCR para identificação dos genótipos G e 52 foram caracterizadas. O genótipo G2 identificado no maior número de amostras. Este genótipo foi identificado como o único genótipo em 23 (42,6\%) das 52 amostras caracterizadas (Tabela 14 e 15). 
Tabela 14: Número de amostras identificadas com cada genótipo considerados isoladamente, através da técnica semi-nested RT-PCR nas amostras de rotavírus identificadas em São Paulo, entre 1994 e 1996.

\begin{tabular}{|c|c|c|c|c|c|c|c|}
\hline \multicolumn{8}{|c|}{ Número de amostras caracterizadas } \\
\hline \multicolumn{4}{|c|}{ Genótipo G } & \multicolumn{4}{|c|}{ Genótipo P } \\
\hline \multicolumn{4}{|c|}{ ÚnicoMistura Total } & \multicolumn{4}{|c|}{ ÚnicoMistura Total } \\
\hline$\overline{\mathbf{G 1}}$ & 7 & 8 & 15 & $P[4]$ & 19 & 11 & 30 \\
\hline G2 & 23 & 14 & 37 & $\mathrm{P}[6 \mathrm{M}]$ & 3 & 9 & 12 \\
\hline G3 & 1 & 2 & 3 & $P[6 G]$ & 0 & 6 & 6 \\
\hline G4 & 1 & 8 & 9 & $P[8]$ & 16 & 12 & 28 \\
\hline G5 & 0 & 11 & 11 & $P[11]$ & 0 & 1 & 1 \\
\hline G6 & 0 & 1 & 1 & & & & \\
\hline G9 & 0 & 6 & 6 & & & & \\
\hline G Neg & 2 & 0 & 2 & & & & \\
\hline
\end{tabular}

Além disso, o genótipo G2 foi encontrado em outras 14 amostras que foram caracterizadas como positivas para mais de um genótipo (Tabela 14). Nestes casos, o genótipo G2 foi encontrado em amostras com dois genótipos: associado em cinco amostras ao genótipo G5, e aos genótipos G6 e G9 em uma amostra cada (Tabela 15). O genótipo G2 também foi encontrado em quatro amostras com três genótipos, duas associado aos genótipos G1 e G3 e outros duas, aos genótipos G4 e G5. Este genótipo foi encontrado também em duas amostras com mais de três genótipos (Tabela 15). No total, 37 amostras reagiram com os primers específicos para o genótipo G2 (Tabela 14).

Entre as amostras coletadas no período de 1994 a 1996, sete (13\%) amostras foram caracterizadas como sendo exclusivamente do genótipo G1. Este genótipo também foi encontrado associado a outros genótipos em oito amostras (Tabela 14). Nestes casos, o genótipo G1 foi encontrado em amostras com dois genótipos distintos: associado aos genótipos G5 em duas amostras, e aos genótipos G2 e G4 em uma amostra cada (Tabela 15). O genótipo G1 também foi encontrado em duas amostras com três genótipos, associado aos genótipos G1 e G3. Além disso, foi encontrado em duas amostras com mais de três genótipos (Tabela 15). 
Tabela 15: Resultado total da genotipagem por RT-PCR das amostras de rotavírus identificadas em São Paulo, Brasil entre 1994 e 1996.

\begin{tabular}{|c|c|c|c|c|c|c|c|c|c|c|c|c|}
\hline \multirow[b]{2}{*}{ Genótipos G } & \multicolumn{11}{|c|}{ Número de amostra com genótipos $\mathrm{P}$} & \multirow[b]{2}{*}{$\%$} \\
\hline & [4] & [6M] & [8] & $\underset{[6 \mathrm{M}]}{[4]}+$ & $\begin{array}{l}{[4]} \\
{[8]}\end{array}$ & $\begin{array}{l}{[6 \mathrm{M}]} \\
{[6 \mathrm{G}]}\end{array}$ & $\underset{[6 \mathrm{G}]}{[8]}$ & $\begin{array}{r}{[4]_{+}} \\
{[6 \mathrm{M}]} \\
{[8]^{+}}\end{array}$ & $\begin{array}{c}{[4]} \\
{[8]} \\
{[11]}\end{array}+$ & $\begin{array}{r}{[4]_{+}} \\
{[6 \mathrm{MM}]_{+}^{+}} \\
{[6 \mathrm{G}]_{+}^{+}} \\
{[8]}\end{array}$ & Total & \\
\hline [1] & & & 5 & & 1 & & & & & 1 & 7 & 13,0 \\
\hline [2] & 17 & 1 & & & 1 & 3 & 1 & & & & 23 & 42,6 \\
\hline [3] & & & & & & & & 1 & & & 1 & 1,9 \\
\hline [4] & & & 1 & & & & & & & & 1 & 1,9 \\
\hline$[1]+[2]$ & & & 1 & & & & & & & & 1 & 1,9 \\
\hline$[1]+[4]$ & & & 1 & & & & & & & & 1 & 1,9 \\
\hline [1]+[5] & 1 & & 1 & & & & & & & & 2 & 3,7 \\
\hline [2]+[5] & & & 1 & 1 & & & 1 & 1 & 1 & & 5 & 9,3 \\
\hline [2]+[6] & 1 & & & & & & & & & & 1 & 1,9 \\
\hline [2]+[9] & & 1 & & & & & & & & & 1 & 1,9 \\
\hline$[4]+[9]$ & & & 1 & & 1 & & & & & & 2 & 3,7 \\
\hline$[1]+[2]+[3]$ & & & 1 & & 1 & & & & & & 2 & 3,7 \\
\hline$[2]+[4]+[5]$ & & & & & & & & 2 & & & 2 & 3,7 \\
\hline$[4]+[5]+[9]$ & & 1 & & & & & & & & & 1 & 1,9 \\
\hline$[1]+[2]+[4]+[9]$ & & & 1 & & & & & & & & 1 & 1,9 \\
\hline$[1]+[2]+[4]+[5]+[9]$ & & & 1 & & & & & & & & 1 & 1,9 \\
\hline Neg & & & 2 & & & & & & & & 2 & 3,7 \\
\hline Total & 19 & 3 & 16 & 1 & 4 & 3 & 2 & 4 & 1 & 1 & 54 & 100,0 \\
\hline
\end{tabular}

P[6G], Gottfried-like; P[6M], M37-like ; neg, negativas

Além destes genótipos, foi identificada uma amostra que foi caracterizada exclusivamente com o genótipo G3 e uma com G4. O genótipo G3 foi identificado em outras duas amostras, associado simultaneamente aos genótipos G1 e G2 (Tabelas 14 e 15). O genótipo G4 também foi encontrado em amostras caracterizadas com mais de um genótipo: em cinco amostras associado ao genótipo G5, em uma amostra cada associado aos genótipos G6 e G9 (Tabela 15). O genótipo G4 também foi encontrado em três amostras com três genótipos, em duas associado aos genótipos G2 e G5 e em uma amostra associado ao G5 e G9, (Tabela 15). Este genótipo também foi encontrado nas duas amostras caracterizadas com mais de três genótipos (Tabela 15). 
Os genótipos G5, G6 e G9 também foram encontrados somente em amostras que foram caracterizadas com misturas de genótipos. O genótipo G5 foi identificado em 11 casos (Tabela 14), associado principalmente ao genótipo G2, tendo sido encontrado também associado aos genótipos G1 G4 e G9 (Tabela 15).

Um total de $20 / 52(38,5 \%)$ amostras foi caracterizado como mistura de genótipos (Tabelas 14 e 15). Todas estas amostras foram testadas com os diferentes primers para os quais reagiram no pool, de forma isolada (reação com primer único), e todas produziram segmentos correspondentes às alturas específicas dos diferentes genótipos. Um exemplo da RT-PCR com primer único é apresentado na Figura 15.

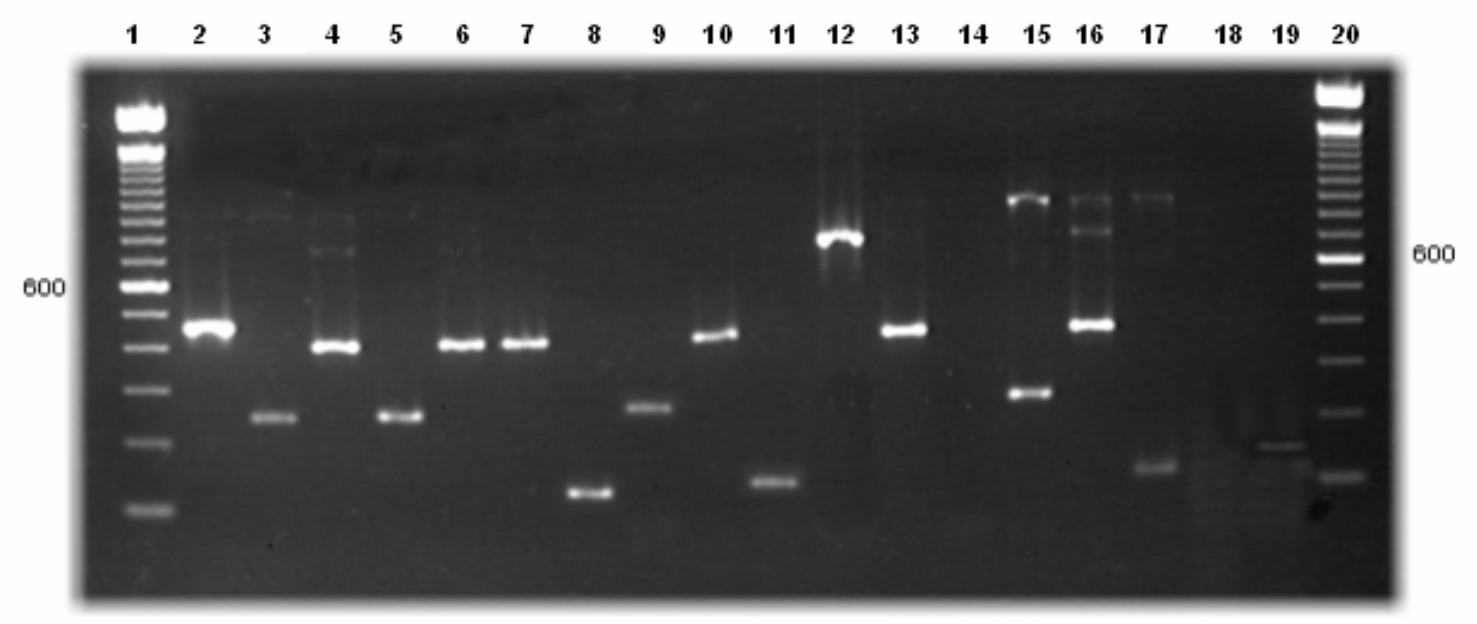

Figura 15: Caracterização molecular por RT-PCR de genótipos G, com primers únicos. Canaletas 1 e 20: padrão de peso molecular 100pb. Canaleta 2: ICB1269 G3. Canaletas 3 e 4: ICB1277 G2 e G4. Canaletas 5 e 6: ICB1299 G2 e G4. Canaletas 7 e 8: ICB1338: G4 e G9. Canaletas 9 e 10: ICB1340 G2 e G4. Canaletas 11 e 12: ICB1344 G9 e G5. Canaleta 13 e 14: ICB1345 G4 e G9 negativa. Canaletas 15, 16 e 17: ICB1347 G2, G4 e G9. Canaleta 18: $\mathrm{H}_{2} \mathrm{O}$ controle negativo. Canaleta 19: amostra padrão HuRv-A/RV4: G1.

Com relação as 160 amostras coletadas durante o ano de 2000, e testadas através da técnica de semi-nested RT-PCR, 158 foram caracterizadas quanto ao genótipo $\mathrm{G}$ (Tabela 16). A grande maioria foi caracterizada como genótipo G1, 120 (75\%). O segundo maior grupo de amostras foi caracterizado como genótipo G9, identificado em 24 (15\%) amostras e o genótipo G4 em 13 
$(8,8 \%)$ amostras. Além disso, uma amostra foi caracterizada como genótipo G3 (Tabela 16).

Tabela 16: Resultado total da genotipagem por RT-PCR das amostras de rotavírus identificadas em São Paulo, em 2000.

\begin{tabular}{lcccc}
\hline & \multicolumn{3}{c}{ Númerol porcentagem (\%) de amostras de genótipos P } \\
\cline { 2 - 5 } Genótipo G & $\mathbf{P}[\mathbf{8}]$ & $\mathbf{P}[\mathbf{1 0}]^{*}$ & PNEG & TOTAL \\
\hline G1 & $94 / 58,8$ & $15 / 9,4$ & $11 / 6,9$ & $120 / 75,0$ \\
G3 & $1 / 0,6$ & $0 / 0,0$ & $0 / 0,0$ & $1 / 0,6$ \\
G4 & $9 / 5,6$ & $2 / 1,3$ & $2 / 1,3$ & $13 / 8,1$ \\
G9 & $19 / 11,9$ & $4 / 2,5$ & $1 / 0,6$ & $24 / 15,0$ \\
GNEG & $2 / 1,3$ & $0 / 0,0$ & $0 / 0,0$ & $2 / 1,3$ \\
TOTAL & $125 / 78,1$ & $21 / 13,1$ & $14 / 8,8$ & $160 / 100$ \\
\hline
\end{tabular}

* Resultado obtido na RT-PCR, não confirmado no sequenciamento.

Entre as 214 amostras analisadas neste estudo, apenas quatro (1,87\%) não foram caracterizadas com os dois grupos de primers utilizados para a caracterização dos genótipos G. Estas amostras também não foram caracterizadas através da técnica da análise de seqüência de DNA por falta de produto de primeira amplificação.

\subsubsection{GENÓTIPOS $P$}

No total, 214 amostras foram analisadas através da técnica de "seminested RT-PCR" utilizando primers específico para a proteína VP4, sendo que 200 (93,5\%) amostras foram caracterizadas com relação ao genótipo P.

Entre as amostras coletadas no período de março de 1994 a março de 1996, 54 amostras foram submetidas à caracterização por semi-nested RT-PCR para identificação dos genótipos $\mathrm{P}$, sendo que todas foram caracterizadas. Entre estas amostras, o genótipo P[4] foi identificado no maior número de casos, tendo sido encontrado em 19 amostras (35,2\%) como o único genótipo (Tabela 14) e em 11 amostras como mistura de genótipos (Tabela 14). Nestes casos o genótipo P[4] foi encontrado em amostras com dois genótipos distintos, associado em quatro amostras ao genótipo P[8], e em uma amostra ao genótipo $\mathrm{P}[6 \mathrm{M}]$ (Tabela 15). O genótipo P[4] também foi encontrado em amostras com três genótipos, em quatro amostras associadas aos genótipos $\mathrm{P}[6 \mathrm{M}]$ e P[8], em 
uma amostra aos genótipos P[8] e P[11]. Este genótipo foi encontrado também em uma amostra com mais de três genótipos (Tabela 15). No total, 30 amostras reagiram com os primers específico para o genótipo P[4] (Tabela 14).

O genótipo $P[8]$ foi encontrado em 16 amostras (29,6\%) como único genótipo e em 12 casos em amostras que reagiram para mais de um genótipo. 0 genótipo $P[8]$ foi identificado associado ao $P[6 \mathrm{G}]$ em duas amostras, e ao genótipo P[4] em quatro amostras. Além disso, o P[8] foi encontrado em todas as seis amostras que reagiram com três ou quatro primers distintos (Tabela 15). No total, o genótipo P[8] foi encontrado em 28 amostras (Tabela 15).

$\mathrm{O}$ P[6M] foi encontrado em três amostras como único genótipo e em nove amostras associado a outros genótipos. Destas, três amostras com o genótipo P2B[6] e em um caso com o genótipo P[4] (Tabelas 14 e 15). Além disso, este genótipo foi encontrado em uma amostra com três genótipos e em outra com quatro genótipos distintos (Tabela 15).

O genótipo $P[6 G]$ não foi encontrado de forma única, mas foi encontrado em seis amostras caracterizadas como misturas: três do genótipo P[6M], duas com o genótipo $\mathrm{P}[8]$ e uma caracterizada por mais de três genótipos.

As misturas de diferentes genótipos $P$ foram encontradas em 16 (29,6\%) amostras (Tabela 15). Todas estas amostras foram testadas com os diferentes primers para os quais reagiram de forma isolada (reação com primer único), e todas produziram segmentos correspondentes às alturas específicas dos diferentes genótipos. Um exemplo da RT-PCR com o pool de primers e amostras que reagiram com mais de um deles é apresentado na Figura 16. 


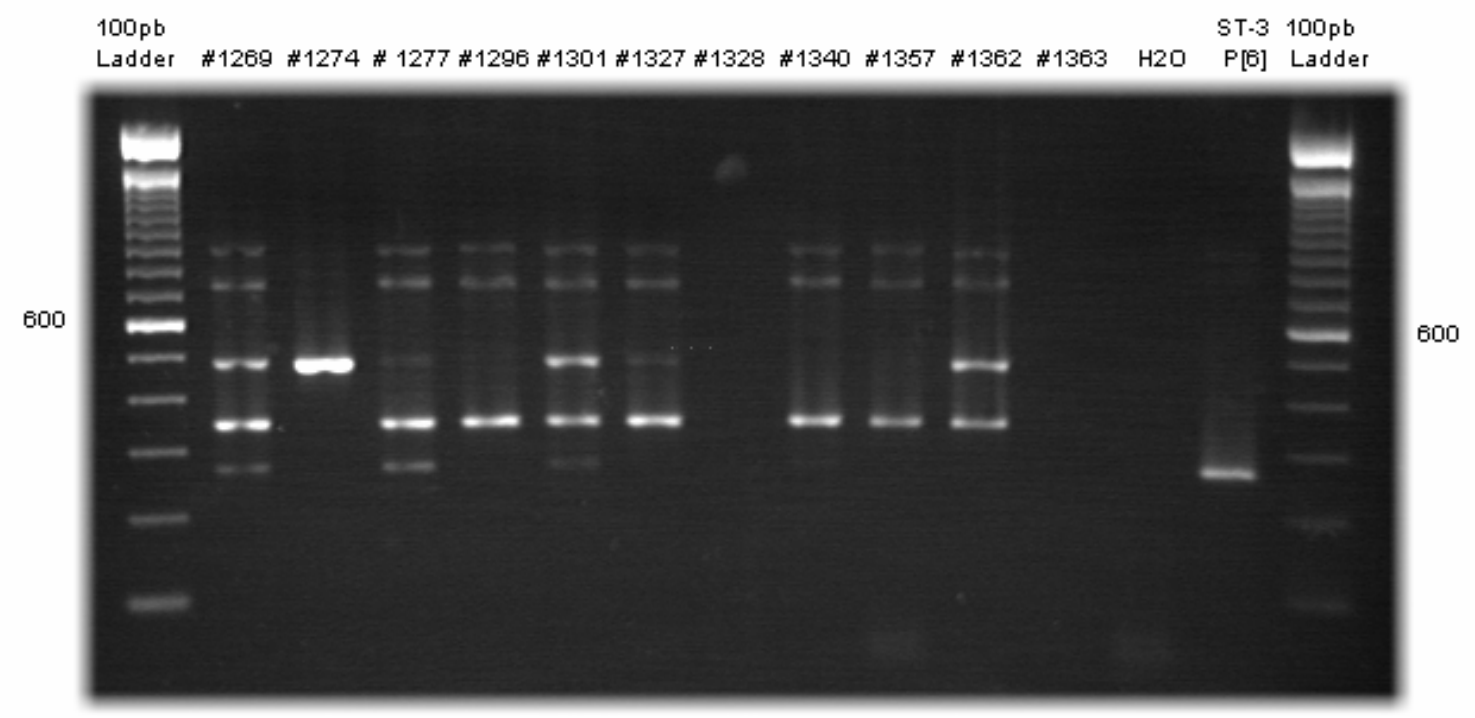

Figura 16: Caracterização molecular por RT-PCR com o pool de primers de genótipos P. As amostras ICB1269, ICB1277, ICB1301 apresentam misturas $\mathrm{P}[4] \mathrm{P}[6 \mathrm{M}] \mathrm{P}[8]$; as amostras ICB1340 e ICB1362, misturas de P[8]P[4]; a amostra ICB1274 P[4]; as amostras ICB1296, ICB1327, ICB1357 P[8]; as amostras ICB1328, ICB1363 negativas. $\mathrm{H}_{2} \mathrm{O}$ controle negativo. Padrão de peso molecular 100pb. Amostra padrão HuRV-A/ST3 P[6].

Com relação as 160 amostras coletadas durante o ano de 2000, e testadas através da técnica de semi-nested RT-PCR, 146 amostras foram caracterizadas quanto ao genótipo P (Tabela 16). Entre estas amostras a grande maioria $125(78,1 \%)$ foi caracterizada como genótipo $P[8]$. Além disso, 21 $(13,1 \%)$ amostras apresentaram um produto de PCR de aproximadamente 580 pb, indicativo do genótipo $P[10]$. Este resultado foi confirmado através de reação com primer único (Tabela 16 e Figura 17). As demais amostras foram caracterizadas como $P$ negativas já que não reagiram com nenhum dos 10 genótipos testados por PCR. Estas amostras não foram caracterizadas através da técnica da análise de sequenciamento de DNA por falta de quantidade suficiente de cDNA da primeira amplificação. 


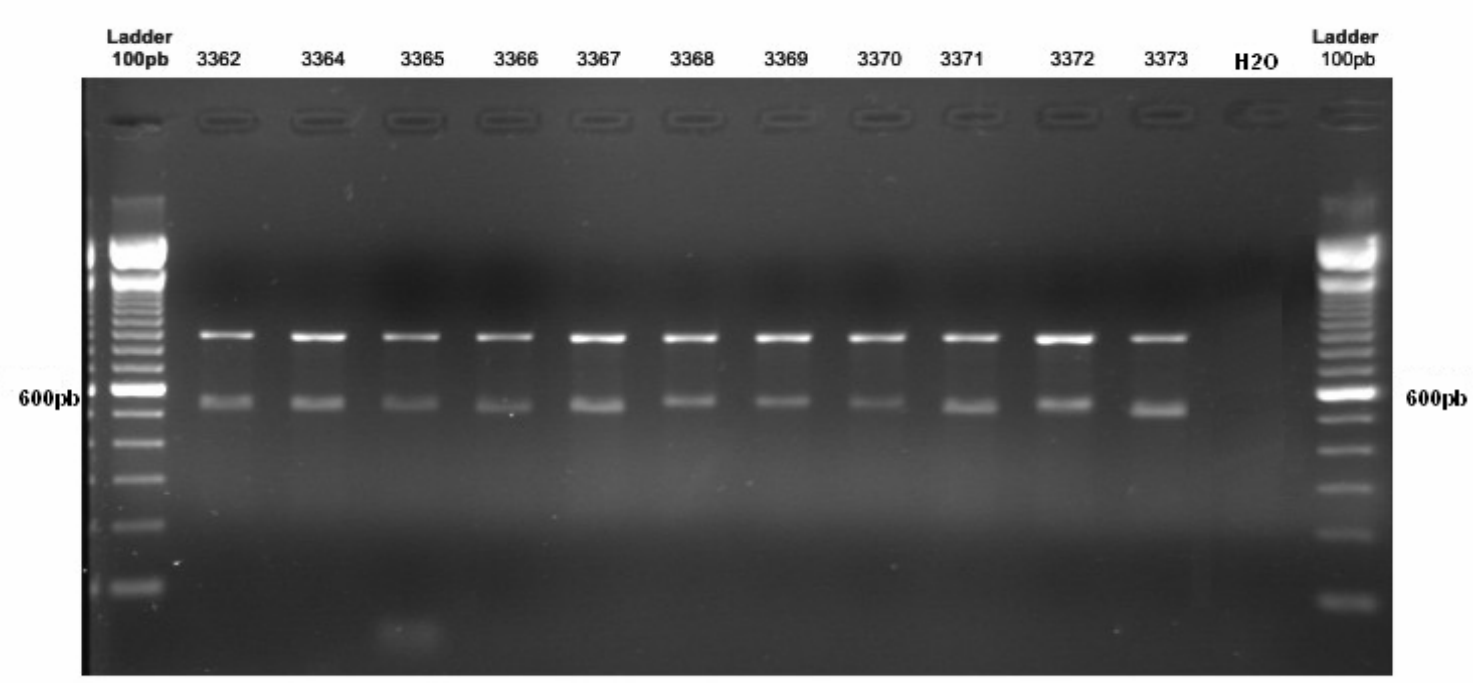

Figura 17: Caracterização molecular por RT-PCR de genótipos P[10], com primers Con3 e 5T1. $\mathrm{H}_{2} \mathrm{O}$ controle negativo. Padrão de peso molecular 100pb.

\subsubsection{ASSOCIAÇÃO DE GENÓTIPOS G E P}

$\mathrm{Na}$ Tabela 15 é possível observar que o genótipo $\mathrm{P}[8]$ foi detectado na maioria dos casos associado com o genótipo G1, apesar de estar também associado a um grande número de amostras com misturas de genótipos $\mathrm{G}$. Ao todo 11 em 16 amostras caracterizadas como P[8] foram identificadas em amostras como misturas de genótipos $\mathrm{G}$.

Por outro lado, o genótipo P[4] foi detectado na maioria das amostras em combinação com os rotavírus G2 (Tabela 15), tendo sido detectado isoladamente apenas em duas amostras com misturas de genótipos $\mathrm{G}$.

Entre as três amostras caracterizadas como P[6M], uma delas ocorreu em combinação com o genótipo $\mathrm{G} 2$ e as outras duas foram identificadas em amostras com a mistura de genótipos de G (Tabela 15).

$\mathrm{Na}$ Tabela 16 é possível observar que o genótipo $\mathrm{P}[8]$ foi detectado associado a todos os genótipos $\mathrm{G}$. Identificados, sendo que o maior número de amostras encontrado foi de G1P[8] 94(58,8\%) das amostras, o seguido pelo grupo de amostras G9P[8] composto por 19 casos. Por outro lado, o genótipo $\mathrm{P}[10]$ atípico, também foi associado a todos os genótipos $\mathrm{G}$. (Tabela 16). 


\subsection{SEQUENCIAMENTO GENÔMICO DE AMOSTRAS COM GENÓTIPO P[10]}

Entre as 21 amostras positivas por semi-nested RT-PCR para o genótipo $P[10], 18$ amostras foram caracterizadas através da técnica do sequenciamento do cDNA. Três amostras não apresentaram quantidade suficiente de DNA para que a reação fosse realizada. Foi realizado o sequenciamento parcial do gene 4 que codifica a proteína VP4 na região correspondente à síntese da proteína VP8* entre os primers con3 e con2, que corresponde a um segmento de $887 \mathrm{pb}$.

As seqüências de nucleotídeos obtidas das amostras e utilizadas para a análise variaram de 825 pb e 868 pb (Tabela 17). Para as análises de identidade, comparação com as amostras protótipos e construção da árvore filogenética foram usados seqüências de 825pb.

As seqüências de nucleotídeos destas amostras foram comparadas entre si e com protótipos de 26 dos 27 genótipos $\mathrm{P}$ de rotavírus de humanos e de animais descritos até maio de 2007. Os protótipos utilizados estão indicados na Tabela 10.

As amostras analisadas apresentaram um percentual de identidade de nucleotídeos variando de 90,2 a 100\% entre si (Tabela 17). Este percentual de identidade demonstra que todas as amostras correspondem a um único genótipo P. Uma pequena diferença de identidade pode ser observada entre quatro amostras (ICB3368; ICB3369; ICB3370 e ICB 3372) que apresentaram os menores percentuais (90,2 a 91\%) com as demais amostras analisadas (Tabela 17). Estes dois grupos aparecem claramente na árvore filogenética resultante da comparação destas amostras com as 26 cepas padrão de genótipos P (Figura 18).

Quando as 18 amostras foram comparadas com os 26 genótipos $\mathrm{P}$ protótipos de rotavírus, as maiores porcentagens de identidade foram observadas em relação à amostra HuRV-A/WA P[8]. 


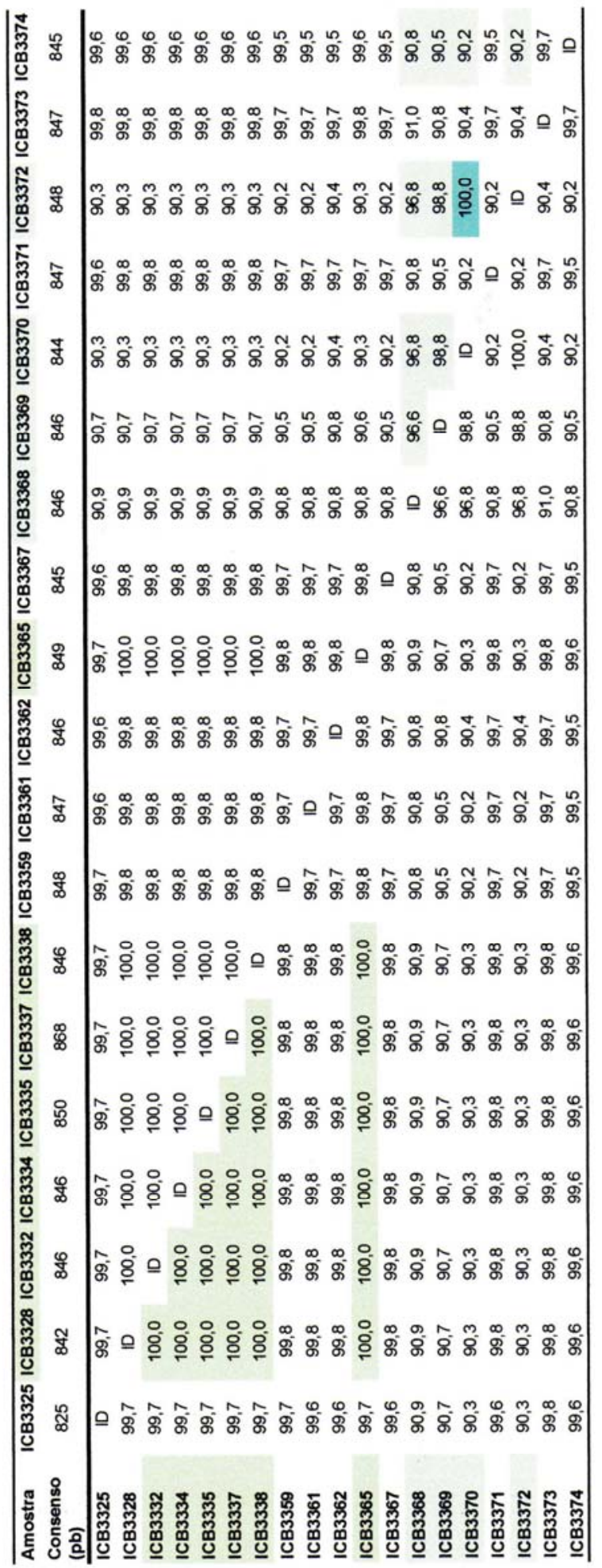




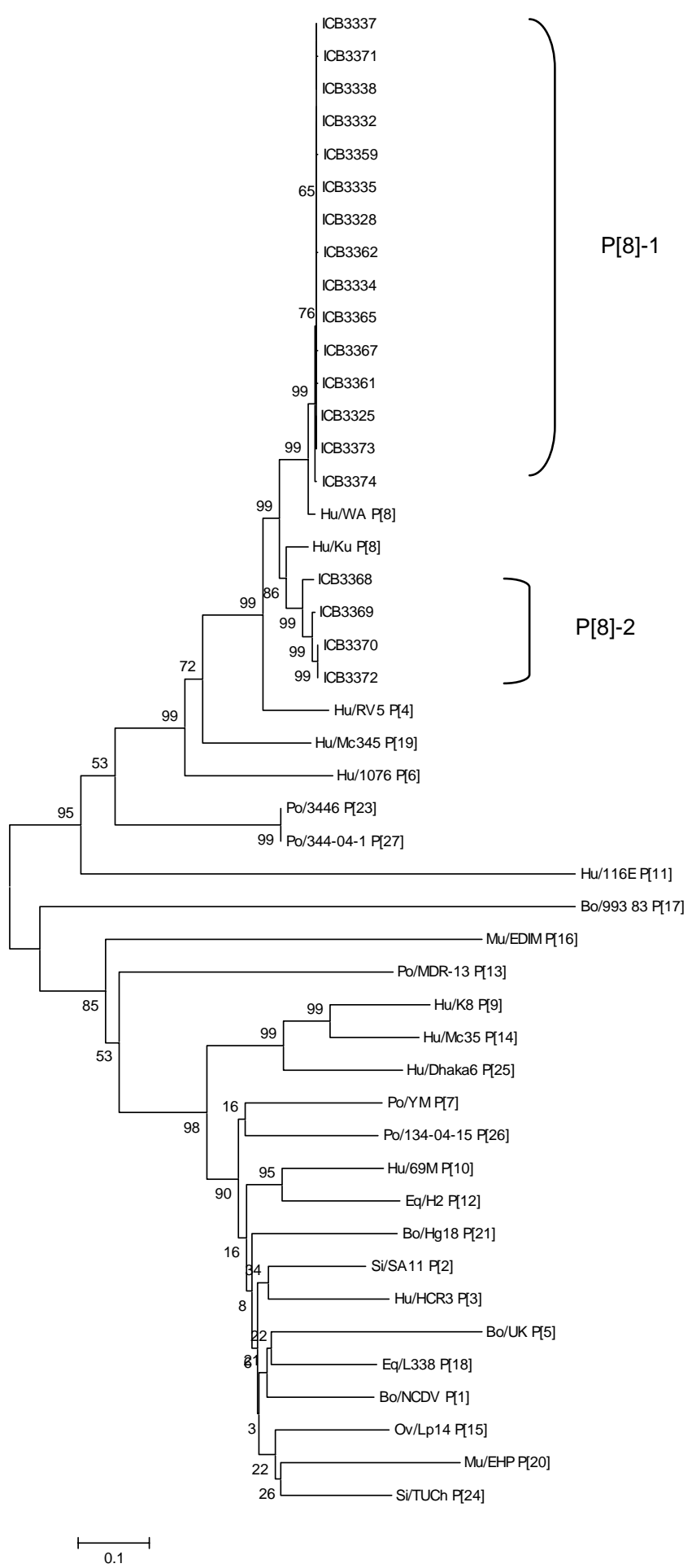

Figura 18: Analise filogenética das seqüências parciais de nucleotídeos que codificam a proteína VP4 de 26 amostras protótipos do genótipo P, comparada as 18 amostras seqüenciadas. Dendrograma construído a partir do método de bootstrap utilizando o programa MEGA 3.1. O número na lateral da árvore representa. Comprimento do ramo indica distância entre as seqüências. 
A identidade de nucleotídeos encontrada em relação à amostra padrão de humana do genótipo P[10], HuRV-A/69M, foi de 45,4 a 46,3\%. Este resultado indica que as amostras identificadas como P[10] através da técnica de RT-PCR não pertencem a este genótipo.

A análise das seqüências de nucleotídeos das amostras do presente no sítio de ligação do primer 1T1 do genótipo P[8], evidenciou a presença de sete nucleotídeos diferentes, o que pode explicar o fato deste primer não ter identificado estas amostras como P[8] (Figura 19).

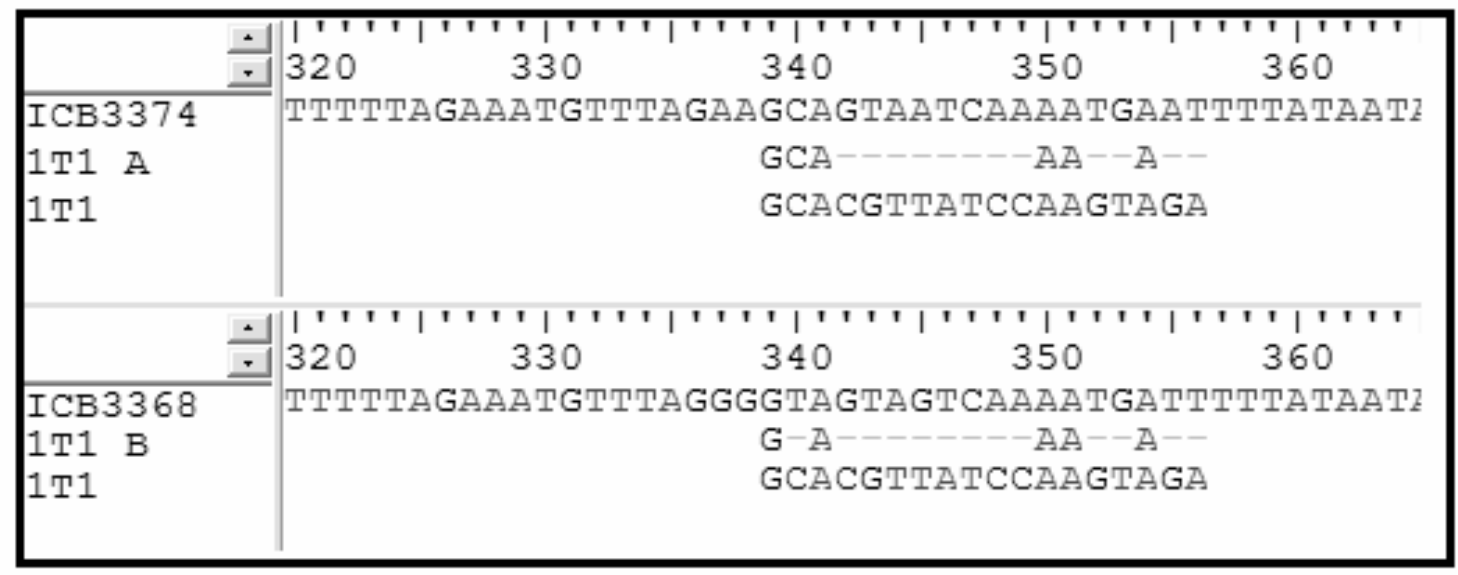

Figura 19: Alinhamento dos fragmentos de VP4, na região do primer 1T1, específico para $P[8]$, com as seqüências reversas complementares deste primer. Os resíduos diferentes do primer nas seqüências $A$ e B são representados por -. A seqüência de nucleotídeos da amostra ICB3374 representa 17 amostras. E a seqüência de nucleotídeos da amostra ICB3368, é representada abaixo.

A Figura 20 apresenta a análise das seqüências de nucleotídeos, das amostras no sítio de ligação do primer 5T1, do genótipo P[10]. Foram encontradas três possibilidades diferentes de ligações do primer a estas amostras todas, entre as posições 550 e 580 todas resultando em um produto de PCR de aproximadamente 583 pb característico do genótipo P[10] (Figura 17). 


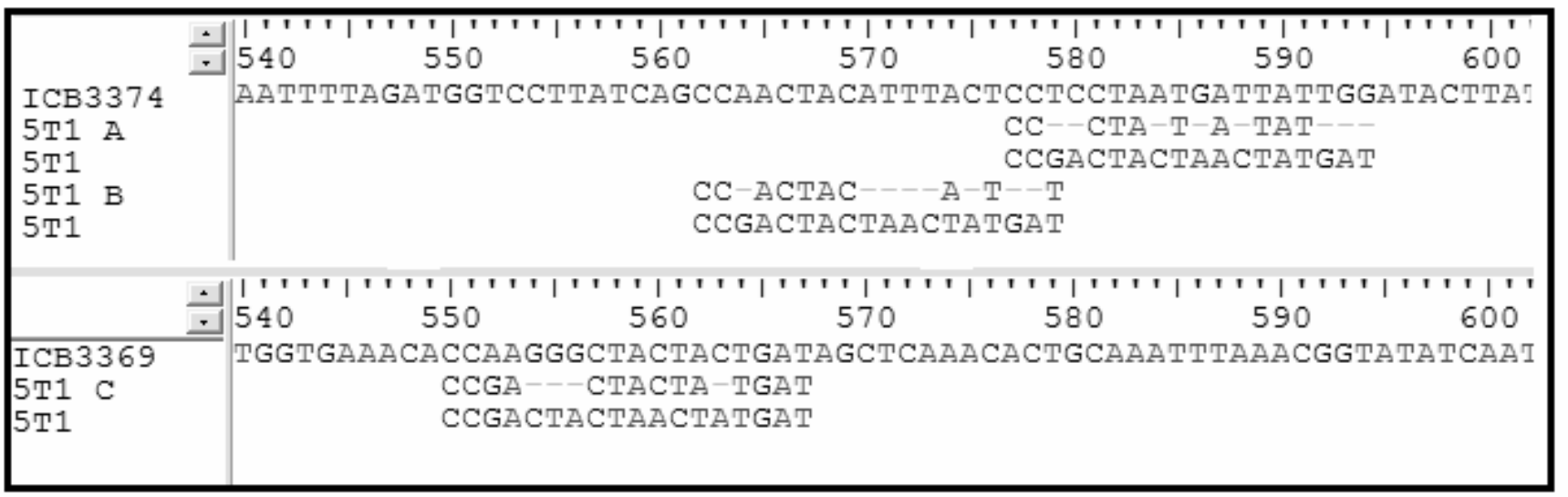

Figura 20: Alinhamento dos fragmentos de VP4, na região do primer 5T1, específico para $P[10]$, com as seqüências reversas complementares deste primer. Os resíduos diferentes do primer nas seqüências $A, B$ e $C$ são representados por -. A seqüência de nucleotídeos da amostra ICB3369 representa as 14 amostras do subtipo P[8]-1 e da amostra ICB3374, as quatro amostras do subtipo $P[8]-2$. 


\section{DISCUSSÃO}

Os rotavírus representam o mais importante agente etiológico de gastroenterites virais. Recentemente, duas vacinas orais vivas para rotavírus foram licenciadas nos EUA (GLASS e PARASHAR, 2006; VESIKARI et al., 2006). Uma delas a, vacina monovalente $P 1 A[8] \mathrm{G} 1$, foi introduzida no calendário brasileiro de vacinação e está em uso na rede da saúde pública. Sua aplicação rotineira iniciou-se em março de 2006, conforme dados do Ministério da Saúde (2007). Estudos que revelem as características das cepas de rotavírus circulantes em nosso país, contribuindo para monitorar e elucidar a ocorrência dos diferentes genótipos e sorotipos são de grande importância para que se adote a melhor estratégia de prevenção.

A triagem das amostras positivas de rotavírus foi realizada com um grupo de 187 amostras de fezes coletadas no Hospital Universitário (HU), de crianças atendidas em ambulatório, no período de março de 1994 a fevereiro de 1996. Neste grupo foram identificadas 54 amostras positivas para rotavírus, o que representa um total de $28,9 \%$ de positividade. Se forem consideradas apenas as amostras de crianças com diarréia (157), a positividade para rotavírus foi de $34,4 \%$. Outros grupos de pesquisa realizaram estudos na América Latina e relatam uma positividade para rotavírus em torno de oito a $42 \%$ dos casos estudados, dependendo do local, da faixa etária e quadro clínico (LINHARES, 2000; KANE et al., 2004).

$\mathrm{Na}$ região Sudeste, vários trabalhos têm sido publicados. Em um dos primeiros trabalhos que foram realizados com amostras coletadas entre 1978 e 1979, em São Paulo, SP, Candeias et al. (1980) utilizando a técnica de imunofluorescência indireta (IFI) analisaram 74 casos de gastroenterites infantis e identificaram $32,6 \%$ de positividade, resultado semelhante ao encontrado neste trabalho.

Rácz et al. (1988) estudaram a presença de rotavírus em amostras fecais de crianças com gastroenterites, utilizando ensaio imunoenzimático. Em um período de 15 meses, foram analisadas 367 amostras de crianças com idades 
entre um mês e 5 anos de idade, com diarréia, e mais 86 controles com a mesma idade, sem diarréia e com infecção respiratória. Foram diagnosticados casos de rotavírus em $15,8 \%$ e $28,1 \%$ em crianças atendidas no ambulatório e internadas, respectivamente. Além disso, foram descritos dois casos de rotavírus entre as crianças do grupo controle. Em nosso trabalho, não foi identificada nenhuma amostra em casos controle.

Em um estudo da etiologia das gastroenterites, realizado em São Paulo, SP, entre 1987 e 1988, Timenestsky et al. (1993) relataram a ocorrência de 19,7\% de casos de rotavírus em crianças com menos de cinco anos de idade e com diarréia, tratadas em ambulatório. Este mesmo trabalho identificou 4,2\% de casos em crianças sem quadro clínico de diarréia.

Entre março de 1994 e junho de 1996, Souza et al. (2002) identificaram 20,8\% de casos de rotavírus entre 154 amostras de crianças atendidas no ambulatório, detectadas através da técnica de IF e contraimunoeletroforese. Em estudo realizado com outras amostras coletadas na mesma época, Carmona et al. (2004) descreveram em um ano a ocorrência de rotavírus em 36,7\% de pacientes internados e, 22,0\% em pacientes ambulatoriais.

Estes resultados demonstram a grande variabilidade na porcentagem de positividade para rotavírus em grupos diferentes de amostras, coletadas de crianças atendidas em ambulatório, na cidade de São Paulo. Tais diferenças podem ser resultado de diferenças no nível sócio-econômico das crianças, do critério de internação utilizado anteriormente, onde as crianças eram internadas com sintomas menos graves ou do ano de coleta das amostras.

Ainda na região Sudeste, em Minas Gerais, MG, Rosa-Silva et al. (2001), em um estudo sobre os aspectos epidemiológicos das rotaviroses, analisaram 656 amostras de crianças de zero a cinco anos atendidas no ambulatório ou hospitalizadas durante o ano de 1998, e observaram a ocorrência de rotavírus em $32,6 \%$ das amostras entre os pacientes hospitalizados e em 3,4\% das amostras coletadas em ambulatório. Em um trabalho mais recente, este mesmo grupo estudou amostras coletadas de janeiro de 1998 a dezembro de 1999, e identificou $29,2 \%$ e $28,6 \%$ amostras positivas para rotavírus em casos de 
crianças hospitalizadas e atendidas no ambulatório, respectivamente. Apenas 2,9\% de HRV-A foram observados entre crianças atendidas em uma clínica particular (ROSA-SILVA et al., 2002).

Resultados observados no Rio de Janeiro apresentaram porcentagens de positividade para rotavírus em torno de 8,2 a $21,0 \%$ dos casos de gastroenterite em crianças. (ARAÚJO et al., 2002; VOLOTÃO et al., 2006; LINHARES, 2000; SANTOS et al.,1990).

Na região Centro-Oeste, em trabalhos realizados em Goiânia e no Distrito Federal, a ocorrência de rotavírus variou de $11,8 \%$ a $37,2 \%$ dos casos de crianças com diarréia (CARDOSO et. al., 1992 e 2003; COSTA et al., 2004; TEIXEIRA et al. 1991)

Resultados bastante diferentes dos obtidos no presente estudo foram relatados por Cardoso et al. (2003), em um estudo com 2605 amostras coletadas em crianças internadas e crianças de ambulatórios e creches, no período de 1986 a 2000. Os resultados para pacientes atendidos no ambulatório foram de $12,5 \%$ de amostras positivas para rotavírus. Por outro lado, Costa et al. (2004), descreveram uma positividade $37,2 \%$ em amostras coletadas de crianças não internadas em hospitais, com diarréia, no período de julho de 2000 a outubro de 2002.

Nas regiões Norte e Nordeste do país, inúmeros trabalhos têm sido publicados relatando a importância dos rotavírus nas gastroenterites infantis (LUZ et al., 2005; CARNEIRO et al.,2005; LINHARES, 2000). Linhares (2000), em uma revisão, destacou alguns estudos que apontaram uma ocorrência de 13 a $40 \%$ de casos de rotavírus nestas regiões.

Recentemente em São Luis, MA, Luz et al. (2005) analisaram 128 amostras de crianças com diarréia, coletadas no período de 1997 a 1999, e identificaram uma porcentagem de HRV-A de 32,0\%. Em Recife, Montenegro et al. (2007) identificaram $35,0 \%$ de positividade para rotavírus em amostras de crianças com menos de cinco anos de idade, atendidas em ambulatório e coletadas no período de 2004 a 2005. Estes resultados são semelhantes aos observados no presente estudo. 
$\mathrm{Na}$ região Sul, estudos realizados nos Estados do Paraná e Santa Catarina descrevem uma porcentagem de positividade variando de quatro a 28,3\% (SCHNACK et al., 2003; PIETRUCHINSKI et al., 2006).

Todos estes resultados relatados evidenciam diferenças nas metodologias empregadas nos diversos trabalhos feitos no Brasil, bem como diferenças na coleta de amostras, diferenças climáticas no país que tem dimensões continentais e diferenças sócio-econômicas das diversas populações estudadas, resultando nas mais variadas porcentagens de positividade no Brasil.

Os resultados obtidos no presente estudo podem também ser comparados aos descritos em outros estudos, realizados em países da América Latina. Coluchi et al. (2002), no Paraguai, estudaram crianças com diarréia, internadas e atendidas em ambulatório, e encontraram porcentagens de 42,5\% e 12,6\% respectivamente. O'Ryan et al. (2001), em um estudo comparativo realizado na Argentina, Chile e Venezuela em crianças hospitalizadas e atendidas em ambulatório, nos anos de 1997 a 1998, encontraram uma porcentagem de HRV-A de 29 a 39\%, para crianças atendidas no ambulatório e de 38 a 71\% em crianças hospitalizadas. Em crianças não-hospitalizadas na Argentina, 39,0\% das amostras foram positivas para rotavírus; no Chile, 34,0\% e na Venezuela, 29,0\%. Assim, o resultado obtido para a Venezuela é o que mais se assemelha ao obtido no presente trabalho.

Com relação as 163 amostras positivas, enviadas pelo laboratório particular, a detecção de rotavírus foi feita pelo kit comercial Rotavírus-strip (Coris BioConcept) e este diagnóstico foi confirmado em nosso laboratório através do EIERA. Apenas três amostras foram positivas pelo kit e negativas pelo EIERA, demonstrando uma concordância de 98,2\% nas amostras positivas para rotavírus, entre os dois testes. Estas amostras também foram negativas pela EGPA. Gabbay et al. (2005) compararam os resultados do Rotavírus-strip com um outro kit comercial, o RotaClone (Meridian Bioscience, Inc), obtendo 100\% de concordância.

Com relação às idades das crianças é possível observar na Tabela 11 que, nas amostras coletadas no $\mathrm{HU}$, a faixa etária com maior porcentagem de 
positividade para rotavírus foi a de sete a 12 meses de idade (37\%). Entre crianças de 13 a 24 meses foram observados $29,4 \%$ de positividade. Este resultado, com maior porcentagem de positivos de sete a doze meses de idade, foi relatado em inúmeras revisões, em amostras coletadas em diferentes partes do mundo, como Estados Unidos (GLASS et al., 1996), Ásia (BRESSE et al., 2005), América Latina (KANE et al., 2004) e Brasil (LINHARES, 2000). Pequenas variações podem ser observadas em decorrência de fatores específicos de cada região estudada (PARASHAR et al., 2003).

$\mathrm{Na}$ Espanha, em um estudo de quatro anos realizado por SánchezFauquier et al. (2004) com amostras coletadas entre 1998 a 2000, foi observado que a maior porcentagem de positividade (45\%) foi encontrada em crianças de seis a doze meses. O mesmo também ocorreu no Reino Unido (ITURRIZAGÓMARA et al., 2000).

No Paraguai, Coluchi et al. (2002) obtiveram resultados diferentes, com a maior porcentagem de positividade ocorrendo em crianças de 12 a 23 meses de idade.

Nas amostras do $\mathrm{HU}$ em crianças de zero a seis meses de idade, o percentual de amostras positivas para rotavírus foi de $24,5 \%$. Valor diferente para esta faixa etária foi descrito em trabalho realizado na Argentina: Bok et al. (2001) encontraram 13\% de positividade para rotavírus em crianças hospitalizadas, com um a seis meses de idade.

$\mathrm{Na}$ Espanha, a porcentagem de positividade em crianças menores de seis meses foi de $27 \%$, resultado semelhante ao encontrado no presente estudo (SÁNCHEZ-FAUQUIER et al., 2004).

Comparando as amostras positivas para rotavírus, enviadas pelo laboratório particular, com relação às idades dos pacientes, é possível observar na Figura 9 que a faixa etária com maior numero de amostras positivas é a de pacientes com sete e 12 meses de idade (61/160, 37\%). Em crianças de 13 a 24 meses foram observados 41/160 (26\%) das amostras positivas. Barril et al. (2006), na Argentina, relataram que 69,1\% das amostras eram de crianças com idades entre seis e 18 meses. Este valor é um pouco superior ao descrito por 
Bok et al. (2001), também na Argentina, que relataram 50\% das amostras positivas ocorrendo em crianças com oito a 11 meses de idade. Bok et al. relataram a ocorrência de $21 \%$ dos casos até os seis meses de idade.

Carmona et al. (2004), em um estudo realizado com amostras coletadas entre 1994 e 1996 de crianças atendidas no Instituto da criança SP, encontraram $91,4 \%$ dos casos associados a crianças de até dois anos de idade. Em nosso trabalho essa faixa etária corresponde a $75,5 \%$ das amostras.

Além disso, se considerarmos a faixa etária de zero a seis meses, nas amostras coletadas no laboratório particular, é possível observar apenas 4,1\% de amostras positivas pertencem a esta faixa etária. Este resultado é bem diferente do observado por Barril et al. (2006), que identificaram um total de 62/201 amostras positivas entre crianças desta mesma faixa etária, correspondendo a $30,8 \%$ das amostras positivas. As amostras analisadas por Barril et al. (2006) foram coletadas em um hospital público na cidade de Córdoba, Argentina.

A diferença dos resultados encontrados no presente estudo, e os relatados por Carmona et al. (2004) e Barril et al. (2006), podem estar relacionados às diferenças sócio-econômicas dos pacientes envolvidos nestes estudos.

Uma diferença semelhante é observada quando comparamos os dois grupos de amostras estudados no presente trabalho. Entre as amostras coletadas no $\mathrm{HU}, 40,6 \%$ das amostras positivas foram identificadas em crianças de zero a seis meses de idade, comparadas a 4,1\% das amostras do laboratório particular. Por outro lado, na faixa etária de 7 a 12 meses de idade, os resultados observados nos dois grupos de amostras é bastante semelhante: $40,6 \%$ no $\mathrm{HU}$ e $42,7 \%$ das amostras positivas do laboratório particular. A partir dos 13 meses de idade os números de amostras positivas encontradas em cada grupo começa a se inverter. No HU, 15,7\% das amostras positivas eram de crianças de 13 a 24 meses de idade e enquanto que nas amostras coletadas no laboratório particular, essa porcentagem foi de 28,7\%. Em crianças de 25 a 60 meses esta diferença é ainda mais visível. Das amostras positivas, apenas 3,1\% 
foram identificadas nesta faixa etária no $\mathrm{HU}$ e $24,5 \%$ nas amostras do laboratório particular (Tabela 12).

Nosso estudo envolve dois grupos sócio-econômicos distintos: a população que freqüenta o serviço público de saúde representada pelo $\mathrm{HU}$, de nível sócio-econômico mais baixo, e a que freqüenta a rede particular de saúde, de nível sócio econômico mais alto. Este fato pode explicar as diferenças de resultados obtidos entre os dois grupos, nas várias faixas etárias estudadas.

Entre as amostras recebidas do laboratório particular, 17 amostras positivas eram de pacientes com mais de cinco anos de idade. Na literatura, os casos de rotavírus nesta faixa etária são normalmente caracterizados por um quadro clínico com uma diarréia branda ou sem diarréia. Estes casos são normalmente associados a adultos que cuidam de crianças hospitalizadas ou a epidemias e surtos (TIMENESTSKY et al., 1996). Iturriza-Gómara et al. (2001) também relatam no período 1995 a 1998, casos esporádicos de infecção de rotavírus em pacientes de 18 a 99 anos. Rubilar-Abreu et al. (2005) observaram, na Suécia, uma alta taxa de positividade para rotavírus G9 entre as pessoas com mais de 15 anos, o que sugere que certos sorotipos emergentes possam vir a infectar adultos sadios de forma sintomática.

Dessas 17 amostras, três (2\% do total) eram de pacientes com mais de 60 anos de idade. Em idosos podem ser observados casos graves e até fatais de infecção por rotavírus (ESTES e KAPIKIAN, 2007). Feeney et al. (2006), na Irlanda, relataram que $6,7 \%$ de amostras positivas foram encontradas em pacientes com idades maiores que 60 anos, confirmando esta possibilidade, ainda que com uma freqüência maior que em nosso trabalho.

No Brasil devido à sua dimensão continental, a distribuição sazonal das gastroenterites associadas a rotavírus apresenta configurações bastante distintas, dependendo região e de suas condições climáticas (INSTITUTO ADOLFO LUTZ, 2004; LINHARES, 2000; COSTA et al., 2005). Nos Estados das regiões Norte e Nordeste, observa-se a ocorrência de rotavírus ao "longo" de todo ano, sem uma época de maior incidência. Entretanto, nas regiões Sudeste, Sul e Centro-Oeste observa-se a maior incidência de casos de rotavírus nos 
meses mais secos, de maio a setembro. Esta característica sazonal da infecção por rotavírus também foi observada no presente trabalho. Nas Figuras 10 e 11, correspondentes aos dois grupos de amostras, é possível observar que o maior número de amostras positivas de HRV-A foram encontrada durante os meses de inverno, que em geral são os meses mais secos do ano em São Paulo.

Além do Brasil, esta sazonalidade também é observada em outros países da América Latina com clima temperado, como Paraguai e Argentina (COLUCHI et al., 2002; GIORDANO et al., 2001) onde a variação da umidade é bastante semelhante à observada na região metropolitana de São Paulo (COLUCHI et al., 2002; KANE et al., 2004). Esse resultado também é encontrado em todos os países de clima temperado do Hemisfério Norte (ESTES e KAPIKIAN, 2007).

Durante o presente trabalho, 218 amostras foram submetidas à técnica de eletroforese em gel de poliacrilamida (EGPA): todas as amostras coletadas no HU (187), três amostras negativas no EIERA e positivas pelo kit Rotavírus-strip da Coris BioConcept e 28 amostras representativas dos diferentes genótipos, obtidos nas 160 amostras enviadas pelo laboratório particular.

Nenhum rotavírus dos grupos não-A foi encontrado por EGPA. Entretanto, no Brasil, alguns casos de rotavírus de grupos não-A são relatados, especialmente rotavírus do grupo C (GABBAY et al., 1999; TEIXEIRA et al., 1998; COX et al., 1998; SOUZA et al., 1998). Estes casos são na maioria das vezes associados a surtos, especialmente de adultos (SOUZA et al., 1998; ESTES e KAPIKIAN, 2007). Nossas amostras não foram coletadas de surtos, o que pode explicar o resultado negativo para rotavírus não-A.

Entre as 82 amostras positivas no EIERA, 78 (95,12\%) foram também positivas por EGPA, o que significa uma boa concordância entre os dois testes. Carmona et al. (2004) relataram uma concordância de 77,1 \% e Coluchi et al. (2002) encontraram uma concordância de $68,2 \%$ entre as duas técnicas. Tais diferenças podem ser devidas a diferenças nas técnicas utilizadas para a EGPA.

De um modo geral, nos dois grupos de amostras deste trabalho, foram observadas uma grande diversidade de eletroferótipo circulando simultaneamente em um mesmo período de tempo. Este resultado é compatível 
com o observado por outros autores. Bishop et al. (2001), em um período de cinco anos, chegou a identificar um total de 90 perfis eletroforéticos (PE) diferentes em algumas regiões da Austrália.

Entre as amostras identificadas no laboratório particular, todas apresentaram perfis eletroforéticos do tipo "longo", com variações na migração dos segmentos 2, 3 e 4, 5 e 6 e/ou 7, 8 e 9. Foram identificados cinco tipos diferentes de PE e não foi possível estabelecer uma correlação destes PE com os diferentes genótipos circulantes.

Entre as amostras coletadas no $\mathrm{HU}$, seis tipos diferentes de PE característicos de HRV-A foram observados. Estes resultados também demonstram a grande variedade de cepas virais em circulação durante um mesmo período.

Entre os PE identificados, foram encontrados quatro tipos "“longo"s", um tipo "'curto"' e um perfil com a migração dos segmentos 10 e 11 diferente da usual, bem próximos e na altura do segmento 10 , quando comparado à amostra padrão SiRV-A/SA11 (Figura 12). Este PE foi descrito por Carmona et al. (2004) em duas amostras identificadas entre agosto 1994 e junho de 1995. No presente estudo nove amostras apresentaram este PE não usual. Entre elas, oito foram identificadas até julho de 1994, enquanto que apenas uma foi encontrada em abril de 1995. Rotavírus com este perfil não usual pode ter tido sua ocorrência limitada a este "curto" período de tempo ou à Cidade de São Paulo, SP.

A predominância de PE "longo" em um determinado período também foi descrita por Rosa-Silva et al. $(2001,2002)$. Nos dois estudos realizados em Minas Gerais, estes autores relataram a ocorrência de dez PE "longo"s em 1998 e mais 13 tipos distintos em 1999.

Vários autores têm relatado no Brasil, e em várias regiões do mundo, a co - circulação de PE "longo"s e "curto"s. Nas regiões Norte e Nordeste, estudos realizados nas cidades de Bélem (MASCARENHAS et al., 2002; GUSMÃO et al., 1999), Recife (MONTENEGRO et al., 2007) e em São Luiz (LUZ et al., 2005); na região Centro-Oeste, em Goiânia (CARDOSO et al., 2000 e 2003) e, no Distrito Federal (TEIXEIRA et al., 1990) e na região Sudeste (CARMONA et al., 2004) 
foram relatadas esta co-circulação. Da mesma forma, este resultado foi encontrado na Hungria (BÁNYAl et al., 2004), na Tunísia (TRABELSI et al., 2000) e no Paraguai (COLUCHI et al., 2002).

Três amostras apresentaram, na EGPA, PE com mais de 11 segmentos de dsRNA, indicativo de uma infecção mista com duas cepas diferentes de rotavírus. Estas amostras também apresentaram múltiplos genótipos. Um resultado semelhante foi descrito anteriormente por outros autores no Brasil (MASCARENHAS et al., 1996) e em outras partes do mundo (TRABELSI et al., 2000; CUNLIFFE et al., 2001).

Mascarenhas et al. (1996) identificaram uma amostra coletada de um paciente de 15 meses de idade, que foi caracterizada como sorotipos G1+G4 e apresentou um PE "longo", com segmentos adicionais. Estas infecções duplas podem conduzir a rearranjos (reassortment) de segmentos do dsRNA, produzindo novos sorotipos/genótipos.

Com relação à caracterização de subgrupo (SG), 48/52 (92,3\%) das amostras positivas para rotavírus coletadas no $\mathrm{HU}$ foram caracterizadas. Os resultados obtidos demonstraram a ocorrência do subgrupo I em 42,3\% das amostras, e o subgrupo II em 50,0\% (Tabela 13). A predominância do subgrupo II em relação ao subgrupo I foi também descrita em várias partes do mundo: África do Sul (STEELE et al., 1988), Paraguai (COLUCHI et al., 2001), Hungria (BÁNYAl et al., 2004), Malawi (CUNLIFFE et al., 2001) e na Índia (JAIN et al., 2001).

No Brasil, Cardoso et al. (2000) encontrou em Goiânia, 55,5\% de amostras SG II, 7,8\% de SGI e 31,1 \% de SG não I-não II.

Mais recentemente em São Paulo, Carmona et al. (2004) descreveram o mesmo fenômeno, quando identificaram somente $22.8 \%$ do SGI e $54,3 \%$ de amostras caracterizadas como SGII; $22,8 \%$ das amostras não foram caracterizadas.

Por outro lado, Gusmão et al. (1999), descreveram entre 1992 e 1994, uma porcentagem exatamente igual $(50,0 \%)$ para ambos os subgrupos, em 237 amostras estudadas em Belém. Nesta mesma região, Mascarenhas et al. (1989) 
também relataram a predominância do SG II, identificando 67\% das amostras de rotavírus positivas para este subgrupo.

Na literatura, o SG I é normalmente associado ao PE "curto" na EGPA, e o SG II ao perfil eletroforético "longo" (ESTES e KAPIKIAN, 2007). No presente estudo, é possível observar esta correlação entre a especificidade de subgrupo e o resultado do EGPA (Tabela 13). A maioria das amostras com PE "longo" foi caracterizada como SG II e as amostras com PE "curto" como SG I.

Em nosso trabalho, foram encontradas duas amostras que não apresentam essa correlação: uma com PE "Iongo" e SGI e a outra com PE "curto" e SGII. Amostras como estas também foram relatadas em outros trabalhos no Brasil (CARDOSO et al., 2000; TEIXEIRA et al., 1990; MASCARENHAS et al., 2002; MONTENEGRO et al., 2007; GUSMÃO et al., 1999) e no mundo (COLUCHI et al., 2001; BÁNYAl et al., 2004; CUNLIFFE et al., 2001; JAIN et al., 2001). Em Goiânia, Cardoso et al. (2000) descreveram a ocorrência de quatro amostras com PE "longo" e SGII entre os anos de 1987 e 1994.

No México Gonzalez-Losa et al. (2005) identificaram, durante um surto que ocorreu entre janeiro e abril de 2000, amostras de HRV-A com ambos os perfis eletroforéticos ("Iongo" e "curto") associados ao SGI.

Todos estes resultados indicam que o SG não pode ser inferido a partir do perfil eletroforético, devido às inúmeras exceções aqui apresentadas.

Estudos de caracterização molecular e sorológica das proteínas VP4 e VP7 têm sido realizados exaustivamente em todo o mundo. Estas proteínas são especialmente importantes na imunogenicidade do rotavírus, já que são responsáveis pela produção de anticorpos neutralizantes durante a infecção. Assim, o estudo das características destas proteínas tem grande relevância em qualquer proposta de prevenção por vacinação (SANTOS e HOSHINO, 2005; GENTSCH et al., 2005; KANE et al., 2004; BRESSE et al., 2005).

Para a caracterização dos sorotipos $G$ utilizou-se um conjunto de anticorpos monoclonais comerciais da Serotec-MA, para os sorotipos G1, G2, G3, G4 e para o grupo A. Entre as 54 amostras testadas, apenas uma amostra 
não pode ser caracterizada para sorotipo, o que corresponde a 98,1\% das amostras. Esta proporção é semelhante à observada por Mascarenhas et al. (2002) de 93,3\% e bem superior à descrita em outros trabalhos realizados no Brasil: Cardoso et al. (2000) caracterizaram apenas 61\% das amostras e Linhares et al. (1988) 50\%.

Durante o presente trabalho, o sorotipo G2 foi detectado no maior número de amostras, $32(59,3 \%)$ e duas amostras foram caracterizadas como G1+G2. Além disso, o sorotipo G1 foi identificado em 18 (33,3\%) das amostras e em uma amostra foi caracterizada como G1+G3. Um resultado semelhante foi observado por Gusmão et al. (1999), que descreveram em Belém, durante os anos de 1992 e 1994, a predominância do sorotipo G2, com o sorotipo G1 observado durante todo o período de estudo. Os sorotipos G1 e G2 foram identificados am ambos os anos, 1994 e 1995. O sorotipo G2 ocorreu em maior freqüência durante 1994 (20/27 - 74,0\%), enquanto que em 1995 uma menor porcentagem de amostras $(10 / 24-41,6 \%)$ foi caracterizada neste sorotipo.

Cardoso et al. (2000) em um estudo sorológico realizado em Goiânia, com amostras coletadas entre 1987 e 1994, descreveram que, no período de 1990 e 1993, o sorotipo G2 foi o mais freqüente. O sorotipo G1 não foi encontrado entre 1990 e 1992, mas reapareceu em 1993, enquanto que o G2 continuou sendo mais freqüente. Em 1994, o sorotipo G1 tornou-se o mais freqüente (CARDOSO et al., 2000). Em nosso trabalho, houve a alternância na maior freqüência de sorotipos, mas sem a substituição do G2 pelo G1.

$\mathrm{Na}$ Hungria, esta alternância de sorotipos foi demonstrada por Bányai et al. (2004), que, em um estudo de oito anos, revelaram a predominância do sorotipo G1 em todos os anos exceto entre 1996 e 1997, quando o sorotipo G2 foi identificado na maioria dos casos. No México, Padilla-Noriega et al. (1990), em um estudo entre 1984 e 1987, demonstram a ocorrência dos sorotipos G1, G3 e G4 em todo o período, entretanto o sorotipo G2 foi encontrado apenas de maio a novembro de 1984 e de agosto de 1986 a janeiro de 1987, desaparecendo entre estes períodos; o sorotipo mais prevalente nesta época foi o G1. Neste mesmo país, nos anos seguintes, entre 1989 e 1990, Gonzalez- 
Losa et al. (2000) descreveram a ocorrência de um surto com 92\% de amostras do sorotipo $\mathrm{G} 2$.

$\mathrm{Na}$ Venezuela, no período de 1988 a 1993, foram identificados os sorotipos G1, G2 e G4. O sorotipo G1 foi identificado em todos os anos, predominando entre 1990 e 1993. No ano de 1992 o sorotipo G2 foi identificado em um número significativo de casos, foi encontrado em todos os anos deste estudo, exceto no ano de 1989, sempre com predomínio de G4 (88-89) e G1 (1990-1993).

Semelhante ao observado no presente estudo, Espul et al. (2000) descreveram na Argentina a predominância do sorotipo G2 nos anos de 1995 e 1996.

Durante este estudo, entre as 32 amostras caracterizadas como sorotipo G2, 10 (31,3\%) apresentaram um PE "longo" na eletroforese em gel de poliacrilamida e SG II, uma associação pouco usual. Na África também foi encontrada esta mesma combinação não usual (TRABELSI et al., 2000). No Brasil, Cardoso et al. (2000) e na Hungria, Bányai et al. (2004) descreveram a ocorrência de outras combinações não usuais: amostras G2 com PE "longo" e SGI.

Bishop et al. (2001), estudando 1845 amostras de HRV-A identificadas entre os anos de 1993 e 1996 na Austrália, identificaram 90 perfis eletroforéticos distintos, sendo 46 associados ao sorotipo $G 1,27$, ao sorotipo $G 2$, oito ao sorotipo G3 e nove ao sorotipo G4. Em nosso trabalho observamos a presença de amostras do sorotipo G1 e G2 associadas aos grandes grupos de perfis eletroforéticos, "longo", "curto" e não usual. O único sorotipo G3 encontrado, em mistura com o G1, também foi caracterizado como PE "longo" e SG1, uma combinação incomum.

Resultados de SG e sorotipo como os deste trabalho reforçam as teorias de segregação independente entre as proteínas VP7 e VP6, apresentada Iturriza-Gómara et al. (2002), e de que a soro prevalência dos diferentes SG e sorotipos/genótipos dos rotavírus podem mudar de ano para ano, como é 
observado para o vírus influenza que também apresenta genoma segmentado (BISHOP et al., 2001; LINHARES, 2000; GENTSCH et al., 2005).

No total, 214 amostras foram analisadas através da técnica de seminested RT-PCR, utilizando primers específicos para a proteína VP7, sendo que 210 (98,1\%) amostras foram caracterizadas para o genótipo G e 200 (93,5\%), para o genótipo $P$. Esta eficiência em genotipagem é maior ou semelhante a outros trabalhos realizados no Brasil. Carmona et al. (2004) estabeleceram os genótipos G e P em 88,6\% das amostras testadas. Leite et al. (2002) genotiparam 88,0\% das amostras para o genótipo G e 91,0\% para o P. Carmona et al. (2006) genotiparam 95,4\% das amostras testadas para o genótipo G e 77,0\% para o genótipo $P$.

Entre as amostras coletadas no período de março de 1994 a março de 1996 no HU, 54 amostras foram submetidas à caracterização por RT-PCR para identificação do genótipo G, e 52 foram caracterizadas. O genótipo G2 foi identificado no maior número de amostras 37 (71,2\%), como o único genótipo em 23 e em mais 14 amostras como misturas de genótipos. O genótipo G1 foi identificado em 15 (27,8\%) amostras, sete como único genótipo e oito em misturas (Tabela 14 e 15). Além destes genótipos, foram identificados os genótipos G3 e G4 como único genótipo, em uma amostra cada, e os genótipos G3, G4, G5, G6 e G9 em misturas de genótipos.

Em um estudo realizado em São Paulo, no período de agosto de 1994 a julho de 1995, Carmona et al. (2004) descreveram a ocorrência dos genótipos G1 (40,0\%), G2 e G3 (11,4\% cada); o genótipo G5 foi observado em 22,8\% como único genótipo, e em 2,8\% associado ao genótipo G2. Apesar da proximidade do período de coleta e deste trabalho ter sido realizado na mesma região do presente estudo, as diferenças entre as proporções de G1 e G2 encontradas nos dois estudos podem ser explicadas pela diferença na coleta das amostras. Carmona et al. (2004) em amostras de pacientes internados, observou uma maior proporção de amostras G1, e detectou uma tendência de associação entre o sorotipo G1 e a gravidade da infecção. Quando os pacientes ambulatoriais são analisados separadamente é possível verificar que a 
proporção encontrada para G1 e G2 é idêntica. As amostras do presente trabalho foram coletadas de pacientes em um ambulatório diferente, o que pode explicar a diferença do genótipo predominante.

Por outro lado, em estudos realizados na Índia e na Argentina também demonstraram a prevalência do genótipo G2. Na Índia, entre os anos de 1996 e 1998, Jain et al. (2001) descreveram a ocorrência do genótipo G2 em 34\% das amostras estudadas, G1, em 18\%, e G9 em 17,0\%. Em Mendoza, Argentina, o genótipo G2 também foi o mais freqüente entre 1995 e 1996, encontrado 65\% das amostras contendo um genótipo único e em mais 10\% das amostras contendo misturas (ESPUL et al, 2000).

No presente estudo o G5 só foi identificado em amostras contendo misturas de genótipos. Este genótipo foi descrito em um grande número de amostras coletadas nos estados de São Paulo, Rio de Janeiro, Pernambuco e Goiás entre os anos de 1983 a 1992 (GOUVEA et al., 1994). Leite et al. (1996) descreveram ainda a ocorrência do genótipo G5 em 9\% das amostras como único genótipo e 12\% de infecções mistas, em amostras coletadas de 1982 até 1994. Mais recentemente, Mascarenhas et al. (2002) relataram a primeira ocorrência do genótipo G5 na região Norte do Brasil, em 4,4\% das amostras.

O genótipo G5 não foi mais detectado em São Paulo a partir de 1996 (Carmona et al., 2006). Consideramos que a detecção de G5 somente em misturas em nosso trabalho indica que este genótipo já estaria desaparecendo nesta cidade.

O relato da ocorrência de outros genótipos animais em humanos especialmente cepas bovinas e suínas são comuns no Brasil e em outros países (SANTOS e HOSHINO, 2005). No Brasil, mais recentemente, alguns trabalhos têm relatado a ocorrência dos genótipos G10 e G8 em vários estados (COX et al., 1998; SANTOS et al., 1998; VOLOTÃO et al., 2006; MONTENEGRO et al., 2007).

O presente trabalho foi o primeiro a identificar uma amostra do genótipo G6 em humanos no Brasil. Este genótipo já foi identificado em humanos em 
outros países como EUA, Austrália, Itália, Hungria, e Bélgica (SANTOS e HOSHINO, 2005).

Entre as amostras coletadas durante o ano de 2000, enviadas pelo laboratório particular, 160 foram analisadas pela técnica de semi-nested RTPCR e 158 (98,8\%) foram caracterizadas quanto ao genótipo G. A maioria das amostras 120 (75,0\%) foram caracterizadas como G1; 24 (15,0\%) amostras como G9 e 13 (8,8\%) como G4. Uma única amostra do genótipo G3P[8] foi caracterizada, confirmando o resultado de G3 obtido na sorotipagem. Na maioria dos trabalhos recentes sobre rotavírus, o genótipo G1 é descrito como o genótipo predominante em todo o mundo (ESTES e KAPIKIAN, 2007; SANTOS e HOSHINO, 2005).

O genótipo G9 tem sido considerado emergente na maioria dos países do mundo, incluindo o Brasil (ESTES e KAPIKIAN, 2007). Santos et al. (2003) descreveram, entre março de 1997 e dezembro de 1999, no Rio de Janeiro e Niterói, além dos genótipos comuns, o genótipo G9 em 25 (15,9\%) das amostras, sendo 19 amostras com infecção única e cinco com misturas de genótipos. Também no Rio de Janeiro, em amostras coletadas de janeiro de 1997 a dezembro 1998, o genótipo G9 foi detectado em 13,0\% amostras (ARAÚJO et al., 2001).

A ocorrência do genótipo G9 também foi relatada por Carmona et al. (2006), em amostras coletadas durante oito anos (1996-2003), em São Paulo, SP. O genótipo G9 foi identificado a partir de 2000 como único genótipo em $17,2 \%$ das amostras, e em 2,4\% das amostras contendo misturas de genótipos.

É importante ressaltar que no Brasil, o genótipo G9 foi detectado a partir de 1997. Entretanto, se considerarmos as misturas de G9 e outros genótipos, relatadas nas amostras do HU no presente trabalho, constata-se que este genótipo já estava circulando em nosso meio desde 1994.

Nas amostras coletadas em 2000 do laboratório particular, o G9 correspondeu a 15,0\% das amostras genotipadas, sendo o segundo genótipo mais freqüente. Esses resultados confirmam os obtidos por Carmona et al. (2006), que também encontram o genótipo G9 como o segundo mais freqüente. 
Em São Paulo, SP, neste mesmo ano. O mesmo resultado foi obtido em Recife, PE, por Montenegro et al. (2007). Santos et al. (2005) analisando amostras de Salvador, BA, caracterizaram 78,8\% das amostras analisadas como G9; também foram identificadas amostras dos genótipos G1 (12,0\%) e G4 (1,4\%). O genótipo G9 foi predominante durante todo os três anos estudados, sendo identificado em 89,2\% das amostras em 1999, 85,3\% em 2000 e em 74,5\% em 2002.

Rubilar-Abreu et al. (2005) observaram na Suécia uma alta taxa de positividade para rotavírus G9 entre pacientes com mais de 15 anos de idade, e sugeriram que certos sorotipos emergentes podem infectar adultos sadios de forma sintomática. Entre as amostras do laboratório particular, descritas no presente estudo, em pacientes com idades entre cinco e 60 anos, o genótipo G9 foi identificado em $3 / 14(21,4 \%)$ das amostras.

A freqüência relativa do genótipo $G 9$ tem aumentado na maioria dos países do mundo, representando 4,1\% das infecções globais por rotavírus. Foram detectados nos Estados Unidos, Japão, Tailândia, Austrália, Bangladesh, Índia, África, Reino Unido, França, Itália, Argentina, Hungria, Paraguai e Albânia (SANTOS e HOSHINO, 2005).

Os presentes resultados confirmam o G9 como um genótipo importante no Brasil e sugerem que próxima geração de vacinas contra rotavírus deverá fornecer proteção adequada contra este genótipo.

No total, 214 amostras foram analisadas através da técnica de seminested RT-PCR utilizando primers específicos para a proteína VP4, sendo que 200 (93,5\%) amostras foram caracterizadas para o genótipo P.

Entre as amostras coletadas no período de março de 1994 a março de 1996, todas as 54 amostras foram caracterizadas. No total, $30(55,6 \%)$ amostras foram identificadas como genótipo P[4], 19 amostras como único genótipo e 11 amostras como mistura de genótipos. O genótipo P[8] foi encontrado em 28 $(51,9 \%)$ amostras, principalmente associado à G1, G5 e G9, isoladamente em 16 amostras e em 12 amostras com mais de um genótipo P. Os genótipos P[4] e P[8] são os mais comuns detectados no Brasil, desde 1982 (CARMONA et al., 2004, CARMONA et al. 2006, SANTOS e HOSHINO, 2005) e os resultados do 
presente trabalho confirmam esses dados. Este resultado, porém é diferente de alguns obtidos para a América do Sul, onde genótipo P[4] foi identificado em $28,1 \%$ das amostras, sempre com a segunda maior freqüência, depois do $P[8]$ (SANTOS e HOSHINO, 2005).

Nosso sistema de genotipagem diferencia entre amostras P[6] de origem humana, semelhante à amostra M37 e P[6] de origem animal, semelhante à amostra Gottfried de suínos (RÁCZ et al., 2000). O genótipo P[6-M37like] foi o terceiro encontrado mais freqüentemente, em 12/54 (22,3\%) das amostras, associado com o genótipo G2 e com misturas contendo G1, G3, G4, G5 e G9. Estas associações são encontradas em muitos países do mundo (SANTOS e HOSHINO, 2005).

No presente trabalho foi identificada uma amostra com o genótipo G2P[6M37], sem misturas. Esta combinação pouco usual foi descrita em várias partes do mundo, entre elas o Brasil (SANTOS e HOSHINO, 2005). No Brasil, Carmona et al. (2006) relataram 7,0\% das amostras do ano de 2001 com este genótipo. Linhares et al. (2002) identificaram, em amostras coletadas de recém-nascidos, de maio 1996 a maio 1998, 18 amostras G2P[6]. Na Argentina entre 1995 e 1996, o genótipo G2P[6] foi identificado em 2 amostras como único genótipo e em uma amostra com misturas de genótipos (Espul et al., 2000).

O genótipo P[6-Gottfried like] foi encontrado apenas em amostras com misturas. A origem deste genótipo, característico de suínos, pode ser a mesma que a das amostras G5, descritas anteriormente neste trabalho.

Com relação as 160 amostras coletadas durante o ano de 2000, 146 amostras foram caracterizadas quanto ao genótipo P. O genótipo $P[8]$ foi identificado em $125(78,1 \%)$ das amostras analisadas. Além disso, a seqüência de nucleotídeos de 18 amostras caracterizadas como P[10] determinou que estas amostras também pertenciam ao genótipo $\mathrm{P}[8]$, resultando em um total de 89,4\% de amostras P[8]. Três amostras, cujo resultado foi P[10] pelo RT-PCR, não foram seqüenciadas, mas provavelmente também pertencem ao genótipo P[8]. Assim, podemos supor que $100 \%$ das amostras caracterizadas neste grupo pertencem a este genótipo. Estes resultados podem ser comparados à maioria 
dos resultados obtidos em todo o mundo. Os genótipos $P[8]$ e $P[4]$ são considerados os mais importantes em infecções humanas e nos últimos 10 anos, o genótipo P[8] tem sido o mais prevalente em todo o mundo, inclusive no Brasil (SANTOS e HOSHINO, 2007).

As combinações mais freqüentemente identificadas em nosso trabalho foram G1P[8] e G2 P[4], que é o resultado encontrado na maioria dos países do mundo (SANTOS e HOSHINO, 2005; GENTSCH et al., 2005, ESTES e KAPIKIAN, 2007).

Nas amostras do HU foram detectadas misturas de genótipos em 20/54 (38,5\%). Na América Latina, porcentagens de zero a $44,1 \%$ foram encontradas no Brasil, inclusive em São Paulo (CARMONA et al., 2004; CARMONA et al. 2006) e em muitos países da América Latina (SANTOS e HOSHINO, 2005). As infecções mistas proporcionam a oportunidade para a evolução dos rotavírus humanos por recombinação (reassortment), pela infecção do mesmo enterócito com dois ou mais rotavírus (CASTELO et al., 2006). A detecção de uma amostra G2P[8] com perfil "longo" na EGPA é uma forte indicação de que esta recombinação já pode ter ocorrido.

Segundo Gentsch et al. (2005), as regiões com maior freqüência de amostras contendo misturas de genotipos são encontradas na Índia, Brasil e Bangladesh. Na Índia, estudos multicêntricos relataram a ocorrência de nove tipos diferentes $G$ e $P$ em uma única amostra (RAMACHANDRAN et al., 1996; JAIN et al., 2001). Nossos resultados mostram duas amostras com seis genótipos diferentes: G2, G4, G5, P[4], P[6 M37-like] e P[8].

As três amostras que apresentaram mais de 11 segmentos na EGPA foram caracterizadas uma como $G 2+G 5 P[8]$ na genotipagem e $G 2$ na sorotipagem; uma como G4+G9P[4]+P[8] na genotipagem e $\mathrm{G} 2$ na sorotipagem e uma como G1P[8] na genotipagem e G2 na sorotipagem. Trabelsi et al. (2000), na Tunísia, nos anos 1995 a 1999, identificaram três amostras com PE com mais de 11 segmentos e estas foram caracterizadas como misturas de sorotipos G (uma $G 1+G 4$ e duas $G 1+G 2$ ) e uma delas também apresentou mistura de genótipos $P(P[4]+P[6])$. Em Malawi, na África, um resultado semelhante foi 
descrito por Cunliffe et al. (2001), que relataram a ocorrência de PE com mais de 11 segmentos em duas amostras que apresentaram misturas de genótipos $P[4]+P[8]$. Nestas duas publicações, bem como no presente trabalho, várias outras misturas foram detectadas por sorotipagem, genotipagem e caracterização de subgrupo, sem apresentar perfil eletroforético com mais de 11 segmentos.

Entretanto, a presença de misturas de genótipos não foi observada em nenhuma das amostras coletadas no laboratório particular. No Brasil, em geral, os pacientes de perfis sócio-econômicos mais baixos são atendidos pelo sistema público de saúde, enquanto que os de perfis sócio-econômicos mais altos são atendidos pelos hospitais e laboratórios particulares. Assim, é possível que este resultado tenha sido influenciado pelas condições sócio-econômicas dos pacientes que utilizaram o laboratório particular. Analisando os resultados obtidos para estas amostras é possível verificar um perfil de genótipos mais próximo do observado em países desenvolvidos, como Estados Unidos, países da Europa e Austrália, onde as misturas de genótipos correspondem a menos de 3,9\% (GENTSCH et al., 2005).

Entre as 17 amostras recebidas do laboratório particular, de maiores de cinco anos de idade, três são de pacientes com mais de 60 anos. Estas amostras foram caracterizadas como G1P[8], G9P[8] e G4P[8]. Feeney et al. (2006) relataram surtos de rotavírus destes mesmos genotipos em idosos, acarretando casos graves de diarréia, na Irlanda.

O genótipo identificado como $\mathrm{P}[10]$ nas amostras coletadas do laboratório particular é muito raramente encontrado em todo mundo, por esta razão decidimos confirmar este resultado como sequenciamento destas amostras.

Entre as 21 amostras positivas por semi-nested RT-PCR para o genótipo $P[10], 18(85,7 \%)$ amostras foram caracterizadas através da técnica do sequenciamento de nucleotídeos do cDNA. Este sequenciamento parcial foi feito a partir do gene que codifica a proteína VP4, na região correspondente à síntese da proteína VP8*, entre os primers con3 e con2, que corresponde a um segmento de $887 \mathrm{pb}$. As seqüências obtidas para análise variaram de $825 \mathrm{pb}$ a 
860 pares de bases. Estas seqüências foram comparadas às de 26 dos 27 genótipos $\mathrm{P}$ padrões de rotavírus de humanos e de animais, descritos até maio de 2007 (MARTELLA et al., 2007).

A comparação das amostras entre elas mostrou um percentual de identidade de nucleotídeos de 90,2 a 100\%, demonstrando que todas as amostras correspondem a um único genótipo $\mathrm{P}$. Quando as seqüências de nucleotídeos destas 18 amostras foram comparadas com amostras padrão de rotavírus, as maiores porcentagens de identidade foram observadas com a amostra HuRV-A/WA P[8] (90,7 a 98\%). A identidade de nucleotídeos encontrada para a amostra padrão humana do genótipo P[10], HuRV-A/69M, foi de 45,4 a $46,3 \%$. Este resultado indica que as amostras identificadas como $\mathrm{P}[10]$, através da técnica de RT-PCR, não pertence deste genótipo, sendo na verdade, amostras do genótipo $\mathrm{P}[8]$.

A análise das seqüências de nucleotídeos das amostras do presente estudo, no sítio de ligação do primer 1T1, específico para o genótipo P[8], foram iguais para todas as amostras. Evidenciou-se a presença de 13 a 14 nucleotídeos diferentes no local de ligação do primer, o que explica o fato deste primer não ter reconhecido estas amostras (Figura 19). Segundo Sommer e Tautz (1989) a presença de três diferenças na região 3' do primer e/ou mais de cinco diferenças na seqüência de um primer de 18 a 20 nucleotídeos seria suficiente para impedir o reconhecimento deste primer. Adah et al. (1997), na Nigéria, relataram problemas no reconhecimento, através de RT-PCR, de amostras do genótipo G8, decorrentes de diferenças na seqüência de nucleotídeos da região 3' do primer. Mais recentemente, Santos et al. (2003) relataram a ocorrência de polimorfismo na seqüência de nucleotídeos de amostras G9, o que prejudicou a identificação deste genótipo através da técnica de RT-PCR.

Iturriza-Gómarra et al. (2000) relataram a ocorrência de polimorfismo na seqüência de nucleotídeos da proteína VP4 em amostras P[8]. Estas amostras não foram caracterizadas como $\mathrm{P}[8]$ por RT-PCR e, quando submetidas à análise da seqüência de DNA, foram caracterizadas como $P[8]$. A análise das 
seqüências revelou diferenças em três a seis nucleotídeos na região do primer 1T1, na maioria dos casos nos quatro primeiros nucleotídeos do terminal 3'. Este sequenciamento revelou também divisão das amostras em três subtipos genômicos $\mathrm{P}[8]$. Um deles era semelhante à amostra padrão HuRV-A/KU, outro semelhante a HuRV-A/WA e um terceiro formado por amostras identificadas no Reino Unido entre 1996 e 1997. Gouvêa et al. (1999) também descreveram duas linhagens filogenéticas diferentes em amostras P[8] do Brasil, Estados Unidos e Japão.

No presente trabalho, quatro amostras (ICB3368; ICB3369; ICB3370 e ICB 3372) também apresentaram um subtipo genômico ou linhagem filogenética $\mathrm{P}[8]-2$ diferente das demais, $\mathrm{P}[8]-1$. Os dois subtipos aparecem claramente na arvore filogenética (Figura 18).

As seqüências da região entre os nucleotídeos 545 a 660, próximos ao local de ligação do primer 5T1, também diferenciam estas quatro amostras P[8]2 das demais do subtipo P[8]-1. Na Figura 20, as 14 outras amostras P[8]-1 são representadas pela seqüência de nucleotídeos da amostra ICB3374, e as quatro amostras P[8]-2 são representadas pela seqüência de nucleotídeos da amostra ICB3369. A Figura 20 apresenta duas possibilidades de ligação do primer 5T1, às amostras do subtipo P[8]-1, uma com apenas cinco diferenças, e outra com oito diferenças, mas com maior identidade na região $3^{\prime}$ do primer. Com relação às amostras do subtipo P[8]-2, é apresentada uma possibilidade de ligação do primer 5T1 com apenas quatro nucleotídeos diferentes.

É importante lembrar também que este primer 5T1, específico para o $\mathrm{P}$ [10] foi desenhado a partir da amostra 69M, identificada em 1991 por Qian e Green (1991). Amostras P[10] não foram descritas na literatura até 2003 por Armah et al. (2003) que descrevam duas amostras P[10] identificadas na África no período de 1998 a 2000. 


\section{CONCLUSÕES}

- Foram identificadas $54 / 187(28,9) \%$ amostras positivas para rotavírus do grupo A nas amostras coletadas no HU/USP, de março de 1994 a fevereiro de 1996.

- A caracterização eletroforética do genoma dos rotavírus revelou uma grande diversidade de cepas virais circulando simultaneamente.

- A caracterização sorológica de grupo, subgrupo e sorotipos dos rotavírus identificados identificou os subgrupos I, II e não-I não-II, com predominância do subgrupo II. A caracterização de sorotipos identificou os sorotipos G1, G2 e G3, com predominância do sorotipo G2.

- A caracterização molecular das amostras positivas para rotavírus quanto aos genótipos identificou diversos genótipos $\mathrm{G}$ e $\mathrm{P}$, circulando de forma simultânea em um mesmo período. O genótipo G2 foi encontrado em maior freqüência (42,6\%), seguido pelo genótipo G1 (13,0\%). Foram identificadas misturas de genótipos G e P em 20/54 (38,5\%) amostras. Foram identificados genótipos característicos de animais (G6; P[6Gottfried like] e P[11]) nas amostras estudadas. Foi ainda caracterizada pela primeira vez, a ocorrência do genótipo G9 no Brasil, desde 1994.

- A caracterização molecular por RT-PCR das amostras positivas para rotavírus, coletadas em um laboratório particular, de fevereiro a outubro de 2000 , identificou os genótipos G1 (75\%), G9 (15,0\%), G4 (8,1\%) e G3 $(0,6 \%)$. Quanto aos genótipos $\mathrm{P}$, foram identificados: $\mathrm{P}[8](78,1 \%)$ e $\mathrm{P}[10]$ $(13,1 \%)$, este último não confirmado. 
- A faixa etária com maior porcentagem de amostras positivas para rotavírus nas amostras do HU/USP foi a de sete a 12 meses de idade. 0 maior número de amostras positivas do laboratório particular também foi identificado nesta faixa etária. Foi detectada uma inversão no número de amostras positivas nas demais faixas etárias, quando os dois grupos de amostras foram comparados. Esta inversão pode estar associada a diferenças sócio-econômicas.

- As amostras positivas para rotavírus foram identificadas em maior número nos meses de inverno, de maio a agosto, nas amostras do HU/USP. O número de amostras positivas recebidas do laboratório particular também foi maior nestes meses.

- Nas amostras do HU/USP foi identificada uma grande diversidade de genótipos $\mathrm{G}$ e $\mathrm{P}$, incluindo um grande número de misturas de genótipos. Nas amostras obtidas no laboratório particular foi identificado um pequeno número de genótipos e não foram observadas misturas. Este resultado pode ser devido às diferenças sócio-econômicas dos pacientes dos dois grupos.

- A análise de seqüência de nucleotídeos do cDNA das amostra P[10] revelou que estas pertencem ao genótipo $P[8]$. Variações na seqüência de nucleotídeos no sítio de ligação do primer 1T1, específico para o $\mathrm{P}[8]$, impediu a identificação deste genótipo nestas amostras. O polimorfismo entre as amostras do genótipo $\mathrm{P}[8]$ ocorreu também na região próxima ao sítio de ligação do primer 5T1, específico para o genótipo $P[10]$, possibilitando de identificação errada destas amostras como $\mathrm{P}[10]$. 
ADAH, M. I.; WADE, A.; OSETO, M.; KUZUYA, M.; TANIGUCHI, K. Detection of human group $C$ rotavíruses in Nigeria and sequence analysis of their genes encoding VP4, VP6 and VP7 proteins. J. Med. Virol., v. 66, p. 269-275, 2002.

AHMED, H. M.; COULTER, J. B.; NAKAGOMI, O.; HART, C. A.; ZAKI, J. M.; ALRABATY, A. A.; DOVE, W.;CUNLIFFE, N. A. Molecular characterization of rotavirus gastroenteritis strains, Iraqi Kurdistan. Emerg. Infect. Dis., v. 12, p. 824-826, 2006.

AHMED, M. U.; KOBAYASHI, N.; WAKUDA, M.; SANEKATA, T.; TANIGUCHI, K.; KADER, A.; NAIK, T. N.; ISHINO, M.; ALAM, M. M.; KOJIMA, K.; MISE, K.; SUMI, A. Genetic analysis of group B human rotaviruses detected in Bangladesh in 2000 and 2001. J. Med. Virol., v. 72, p. 149-155. 2004.

ALFIERI, A. A.; ALFIERI, A. F.; FREITAS, J. C.; SILVA, C. A.; FREIRE, R. L.; BARROS, A. R.; BARREIROS, M. A. B.; MULLER, E. E. Ocorrência de Escherichia coli, rotavírus, picobirnavirus e C. parvum em um foco de diarréia do pós-desmame em suínos. Semina Ci. Agr., v. 15, p. 5-7, 1994.

ANAND T.; RAJU T. A.; RAO M. V.; RAO L. V.; SHARMA G. Symptomatic human rotavirus subgroups, serotypes \& electropherotypes in Hyderabad, India. Indian J. Med. Res., v. 112, p. 1-4, 2000.

ARAUJO, I. T.; FIALHO, A. M.; DE ASSIS, R. M.; ROCHA, M.; GALVAO, M.; CRUZ, C. M.; FERREIRA, M. S.; LEITE, J. P. Rotavirus strain diversity in Rio de Janeiro, Brazil: characterization of VP4 and VP7 genotypes in hospitalized children. J. Trop. Pediatr., V. 48, p. 214-218, 2002.

ARMAH, G. E.; STEELE, A. D.; BINKA, F. N.; ESONA, M. D.; ASMAH, R. H.; ANTO, F.; BROWN, D.; GREEN, J.; CUTTS, F.; HALL, A. Changing patterns of rotavirus genotypes in ghana: emergence of human rotavirus G9 as a major cause of diarrhea in children. J Clin Microbiol., v. 41, p. 2317-2322, 2003.

ASENSI, M. T.; MARTINEZ-COSTA, C; BUESA, J. Anti-rotavirus Antibodies in Human Milk: Quantification and NeutralizingActivity. J. Pediatr. Gastroenterol. Nutr., v. 42, p. 560-567, 2006.

AWACHAT, P. S.; KELKAR, S. D. Dual infection due to simian G3--human reassortant and human G9 strains of rotavirus in a child and subsequent spread of serotype G9, leading to diarrhea among grandparents. J. Med. Virol., v. 78, p. 134-138, 2006.

BÁNYAI, K.; GENTSCH, J.; GLASS, R. I.; ÚJ, M.; MIHÁLY, I.; SZUCS G. Eight-year survey of human rotavirus strains demonstrates circulation of unusual $G$ and $P$ types in Hungary. J. Clin. Microbiol., v. 42, p. 393-397, 2004.

BARMAN, P.; GHOSH, S.; SAMAJDAR, S.; MITRA, U.; DUTTA, P.; BHATTACHARYA, S. K.; KRISHNAN, T.; KOBAYASHI, N.; NAIK, T. N. RT-PCR based diagnosis revealed importance of human group B rotavirus infection in childhood diarrhoea. J. Clin. . Virol., v. 36, p. 222-227, 2006. 
BASS, D. M.; BAYLOR, M. R.; CHEN, C.; MACKOW, E. R.; BREMONT, M.; GREENBERG, H. B . Lipossome-mediated transfection of intact viral particles reveals that plasma membrane penetration determines permissivity of tissue culture cells to rotavirus. J. Clin. Invest., v. 90, p. 2313-2320, 1992.

BEARDS, G. M. Polymorphism of genomic RNAs within rotavirus serotypes and subgroups. Arch. Virol., v. 74, p. 65-70, 1982.

BERKOVA, Z.; CRAWFORD, S. E.; TRUGNAN, G.; YOSHIMORI, T.; MORRIS, A. P.; ESTES, M. K. Rotavirus NSP4 induces a novel vesicular compartment regulated by calcium and associated with viroplasms. J. Virol., v. 80, p. 6061-6071, 2006.

BERNSTEIN, D. I.; GLASS, R. I.; RODGERS, G.; DAVIDSON, B. L.; SACK, D. A. Evaluation of rhesus rotavirus monovalent and tetravalent reassortant vaccines in US children. US Rotavirus Vaccine Efficacy Group. JAMA. v. 273, p. 1191-1196, 1995.

BINGNAN, F.; UNICOMB, L. E.; GUANGLI, T.; ALI, A.; MALEK, A.; RAHIM, Z.; TZIPORI, S. . Cultivation and characterization of novel human group A rotaviruses with long RNA electropherotypes, subgroup II specificities and serotype 2 VP7 gene. J. Clin. Microbiol., v. 29, p. 2224-2227, 1991.

BISHOP, R. F.; CAMERON, D. J. S.; VEENSTRA, A. A.; BARNES, G. L. Diarrhea and rotavirus infection associated with differing regimens for postnatal care of newborn babies. J. Clin. Microbiol., v. 9, p. 525-529, 1979.

BISHOP, R. F.; DAVIDSON, G. P.; HOLMES, I. H.; RUCK, B. J. . Evidence for viral gastroenteritis. New Engl. J. Med., v. 289, p. 1096-1097, 1973b.

BISHOP, R. F.; DAVIDSON, G. P.; HOLMES, I. H.; RUCK, B. J. Detection of a new virus by electron microscopy of faecal extracts from children with acute gastroenteritis. Lancet, v. 1, p. 149-151, 1974.

BISHOP, R. F.; DAVIDSON, G. P.; HOLMES, I. H.; RUCK, B. J. Virus particles in epithelial cells of duodenal mucosa from children with acute non-bacterial gastroenteritis. Lancet, v. 2, p. 1281-1283, 1973a.

BITTENCOURT, M. J.; Rácz, M. L. Electrophoretic study of the genome of porcine rotaviruses from São Paulo, Brazil. Rev. Microbiol., v. 23, p. 149-151, 1992.

BOTH, G. W.; BELLAMY, A. R.; MITCHELL, D. B. Rotavirus protein structure and function. In: Rotaviruses. Ed. R. F. Ramig. Berlin, Springer - Verlag, 1994. p. 67-105.

BRANDT, C. D.; KIM, H. W.; RODRIGUEZ, W. J.; THOMAS, L.; YOLKEN, R. H.; ARROBIO, J. O.; KAPIKIAN, A. Z.; PARROTT, R. H.; CHANOCK, R. M. Comparison of direct electron microscopy, immune electron microscopy and rotavirus enzyme-linked immunosorbent assay for detection for gastroenteritis viruses in children. J. Clin. Microbiol., v. 13, p. 976-981, 1981.

BRESEE, J. S.; HUMMELMAN, E.; NELSON, E. A.; GLASS, R. I. Rotavirus in Asia: the value of surveillance for informing decisions about the introduction of new vaccines. $\mathbf{J}$. Infect. Dis., v. 192- Suppl 1, p. S1-S5, 2005. 
BRESEE, J. S.; PARASHAR, U. D.; WIDDOWSON, M. A.; GENTSCH, J. R.; STEELE, A. D.; GLASS, R. I. Update on rotavirus vaccines. Pediatr. Infect. Dis. J., v. 24, p. 947952, 2005.

BURKE B.; DESSELBERGER, U. Rotavirus pathogenicity. Virology, v. 218, p. 299-305, 1996.

CANDEIAS, J. A. N.; BALDACCI, E. R.; BREVIGLIERI, J. C.; GRISI, S. J. E.; RÁCZ, M. L.; HARSI, C. M. Diagnóstico de infecções por rotavírus através da reação de imunofluorescencia indireta. Rev. Microbiol., v. 11, p. 76-78, 1980.

CANDEIAS, J. A. N.; ROSENBURG, C. P.; RÁCZ, M. L. Identificação por contraimunoeletroforese de rotavírus em casos de diarréia infantil. Rev. Saúde Publ. São Paulo, v. 12, p. 99-103, 1978.

CARDOSO, D. D. P.; BRITO, W. M. E. D.; MARTINS, R. M. B.; KITAJIMA, E. W.; SOUZA, M. P. M.; BARBOSA, A. J.; OLIVEIRA, S. A.; RASCOPI, S. B. Ocorrência de rotavírus e adenovírus em amostras fecais de crianças com gastroenterite, na cidade de Goiânia. Rev. Soc. Bras. Med. Trop., v. 22, p. 67-71, 1989.

CARDOSO, D. D. P.; MARTINS, R. M. B.; KITAJIMA, E. W.; BARBOSA, A. J.; CAMAROTA, S. C. T.; AZEVEDO, M. S. P. Rotavírus e adenovírus em crianças de 0-5 anos hospitalizadas com ou sem gastroenterite em Goiânia-GO., Brasil. Rev. Inst. Med. Trop. São Paulo., v. 34, p. 433-439, 1992.

CARDOSO, D. D. P.; SOARES, C. M. A.; AZEVEDO, M. S. P.; LEITE, J. P. G.; MUNFORD, V.; RÁCZ, M. L. Serotypes and subgroups of rotavirus in central Brazil. J. Health Popul. Nutr. v. 18, p. 39-43, 2000.

CARMONA, R. C. C.; TIMENETSKY, M. C. S. T.; MORILLO, S. G.; RICHTZENHAIN, L. J. Human rotavirus serotype G9; São Paulo; Brazil; 1996-2003. Emerging. Infect. Dis., v. 12, p., 963-968, 2006.

CARMONA, R. C. C.; TIMENETSKY, M. C. S. T.; SILVA, F. F.; GRANTO, C. F. H. Characterization of rotavírus strains from hospitalized and outpatient children with acute diarrhoea in São Paulo; Brazil. J. Med. Virol., v. 74, p. 166-172, 2004.

CARNEIRO, N. B.; DINIZ-SANTOS, D. R.; FAGUNDES, S. Q.; NEVES, L. L.; REGES R. M.; LIMA, E. K.; QUADROS, V. H.; SOARES, L. E.; SILVA, F. S.; SCHNEITER Hde, G.; FIGUEIREDO, I.; SILVA, L. R. Clinical and epidemiological aspects of children hospitalized with severe rotavirus-associated gastroenteritis in Salvador, BA, Brazil. Braz. J. Infect. Dis., v. 9, p. 525-528, 2005.

CARNIELI, P. JR.; BRANDÃO, P. E.; CARRIERI, M. L.; CASTILHO, J. G.; MACEDO, C. I.; MACHADO, L. M.; RANGEL, N.; DE CARVALHO, R. C.; DE CARVALHO, V. A.; MONTEBELLO, L.; WADA, M.; KOTAIT, I. . Molecular epidemiology of rabies virus strains isolated from wild canids in Northeastern Brazil. Virus Res., v. 120, p. 113-20, 2006. 
CARUZO, T. A. R. Caracterização de misturas de genótipos $\mathbf{G}$ e $\mathbf{P}$ de rotavírus de bovinos do estado de Goiás, Brasil: Ocorrência de genótipos característicos de rotavírus humanos.121f Tese (Doutorado em Ciências) - Instituto de Ciências Biomédicas, Universidade de São Paulo, São Paulo, 2006.

CASTELLO, A., ARVAY, M. L.; GLASS, R. I.; GENTSCH,J. Rotavirus strain surveillance in Latin America a review of last nine years. Pediatr. Infect. Dis. J., v. 23, p. S168S172, 2004.

CENTERS FOR DISEASE CONTROL AND PREVENTION (CDC), 1999a. Recommended childhood immunization schedule--United States, 1999. MMWR, v. 15, p. 12-16.

CENTERS FOR DISEASE CONTROL AND PREVENTION (CDC), 1999b. Intussusception among recipients of rotavirus vaccine-United States, 1998-1999. MMWR, v. 16, p. 577-81.

CHEN, G.; HUNG, T.; BRIDGER, J. C.; MCCRAE, M. A. Chinese adult rotavirus is a group B rotavirus. Lancet, v. 2, p. 1123-1124, 1985.

CHEN,Z.; LAMBDEN, P. R.; LAU, J.; CAUL, E. O.; CLARKE, I. N. Human group C rotavirus: completion of the genome sequence and gene coding assignments of a noncultivatable rotavirus. Virus Res., v. 26, p. 179-187. 2002.

COLUCHI, N.; MUNFORD, V.; MANZUR, J; VAZQUEZ, C; ESCOBAR, M; WEBER, E; MÁRMOL, P; RÁCZ, M. L. . Detection, subgroup specificity and genotype diversity of rotavirus strains in children with acute diarrhea in Paraguay. J. Clin. Microbiol., v. 40, p. 1709-1714, 2002.

COOK, N.; BRIDGER, J, KENDALL, K.; GOMARA, M. I.; EL-ATTAR, L.; GRAY, J. The zoonotic potential of rotavirus. J. Infect., v.48, p. 289-302, 2004.

COOK, S. M.; GLASS, R. I.; LEBARON, C. W.; HO, M. S. Global seasonality of rotavirus infections. WHO bulletin OMS. v. 68, p. 171-177, 1990.

COSTA, P. S. S.; CARDOSO D. D. P.; GRISI, S. J. E. Rotavírus A e sua profilaxia vacinal. Rev. Patol. Trop. v. 34, p. 1-16, 2005.

COULSON, B. S.; GENTSCH, J. R.; DAS, B. K.; BHAN, M. K.; GLASS, R. I. Comparison of enzyme immunoassay and reverse transcriptase PCR for identification of serotype G9 rotaviruses. J. Clin. Microbiol., v. 37, p. 3187-3193, 1999.

COULSON, B. S.; GRIMWOOD, K.; HUDSON, I. L.; BARNES, G. L.; BISHOP, R. F. Role of coproantibody in clinical protection of children during reinfection with rotavirus. $\mathbf{J}$. Clin. Microbiol., v.30, p. 1678-1684, 1992.

COULSON, B. S.; WITTERICK, P. D.; TAN, Y.; HEWISH, M. J.; MOUNTFORD, J. N.; HARRISON, L. C.; Honeyman, M. C. Growth of rotaviruses in primary pancreatic cells. J. Virol., v. 76, p. 9537-9544, 2002. 
COX, M. J.; JAMES, V. L; AZEVEDO, R. S; MASSAD, E.; MEDLEY, G. F. Infection with group $C$ rotavirus in a suburban community in Brazil. Trop. Med. Int. Health. v. 3, p. 891-895, 1998.

CRAWFORD, S. E.; PATEL, D. G.; CHENG, E.; BERKOVA, Z.; HYSER, J. M.; CIARLET, M.; FINEGOLD M. J.; CONNER, M. E.; ESTES, M. K. Rotavirus viremia and extraintestinal viral infection in the neonatal ratmodel. J. Virol., v. 80, p. 4820-4832, 2006.

CUNLIFFE, N. A.; GONDWE J. S.; GRAHAN S. M.; THINDWA, B. D. M; DOVE, W.; BROADHEAD, R. L.; MOLYNEUX, M. E.; HART A. C. Rotavirus strain diversity in Blantyre, Malawi, from 1997 to 1999. J. Clin. Microbiol., v. 39. p. 836-843, 2001.

DELPIANO, M. L.; RIQUElME, R. J.; CASADO, F. M. C.; AlvAREZ, H. X. Clinical features and costs of rotavirus gastroenteritis in infants: community versus nosocomialy acquired infection. Rev. Chilena Infectol., v. 23, p. 35-42, 2006.

DORMITZER, P.R., NASON, E.B., PRASAD, B.V., HARRISON, S.C. Structural rearrangements in the membrane penetration protein of a non-enveloped virus. Nature, v. 26, p.1053-1058, 2004.

DUTTA, P.; BHATTACHARYA, S. K.; SAHA, M. R.; DUTTA, D.; BHATTACHARYA, M. K.; MITRA, A. K. Nosocomial rotavirus diarrhea in two medical wards of a pediatric hospital in Calcutta. Indian pediatrics, v. 29, p. 701-706, 1992.

SOUZA, E. C.; MARTINEZ, M. B.; TADDEI, C. R.; MUKAI, L.; GILIO, A. E.; RÁCZ, M. L.; SILVA, L.; EZENBERG, B.; OKAY, Y. Etiologic profile of acute diarrhea in children in São Paulo. J.Pediatr., v. 1, p. 31-38, 2002.

ELLENS, D. J.; LEEUW, P. W.; STRAVER, P. J.; VAN BALKEN, J. A. M. Comparison of five diagnostic methods for the detection of rotavirus antigen in calf faeces. Med. Microbiol. Immunol., v. 166, p. 157-163, 1978.

ESPEJO, R. T.; LOPEZ, S.; ARIAS, C. F. Structural polypeptides of simian rotavirus SA11 and the effect of trypsin. J. Virol, v. 37, p. 156-160, 1981.

ESTES, M. K. Rotaviruses and their replication. In: Fields Virology, edited by D. M. Knipe and P. M. Howley, Philadelphia:Lippincott Williams \& Wilkins, 2001, p. 1747-1785.

ESTES, M. K. . Rotaviruse: molecular biology. In: Encyclopedia of Virology, edited by R. G. Webster and A. Granoff, London:Academic Press Limited, 1994, p. 1281-1290.

ESTES, M. K. Rotavirus and their replication. In: Fields Virology, edited by D. M. Knipe and P. M. Howley, Philadelphia:Linppincott Williams \& Wikins, 2001, p. 1747-1833.

ESTES, M. K.; COHEN, J. Rotavirus gene structure and function. Microbiol. Rev., v. 53: p. 410-49, 1989.

ESTES, M. K.; GRAHAM, D. Y.; DIMITROV, D. H. . The molecular epidemiology of rotavirus gastroenteritis. Prog. med. Virol., v. 29, p. 1-22, 1984. 
ESTES, M. K.; GRAHAM, D. Y.; MASON, B. B. Proteolytic enhancement of rotavirus infectivity: molecular mechanisms. J. Virol. v. 39, p. 879-888, 1981.

ESTES, M. K.; KAPIKIAN, A. Z. Rotaviruses. In: Fields Virology, edited by D. M. Knipe and P. M. Howley, Philadelphia:Lippincott Williams \& Wilkins, p. 1917-1974, 2007.

ESTES, M. K.; PALMER, E. L.; OBIJESKI, J. F. Rotavirus: a review. Curr. Top. Microbiol. Immunol. v. 105, p. 123-184, 1983.

FAUQUET, C. M.; MAYO, M. A.; MANILOFF; J.; DESSELBERGER, U.; BALL, L. A. Virus taxonomy. Eighth report of the Intenational Committee on Taxonomy of Viruses., San Diego, CA: Academic Press,. p. 447-496, 2007.

FENAUX, M.; CUADRAS, M. A.; FENG, N.; JAIMES, M.; GREENBERG, H. B. Extraintestinal spread and replication of a homologous EC rotavirus strain and a heterologous rhesus rotavirus in BALB/c mice. J. Virol., v. 80, p. 5219-5232, 2006.

FISCHER, T. K.; BRESEE, J. S.; GLASS, R. I. . Rotavirus vaccines and the prevention of hospital-acquired diarrhea in children. Vaccine, v. 22s, p. s49-s54, 2004.

FLEWETT, T. H.; BRYDEN, A. S.; DAVIES, H.; WOODS, G. N.; BRIDGER, J. C.; DERRICK, J. M. Relation between viruses from acute gastroenteritis of children and newborn calves. Lancet, v. 2, p. 61-63, 1974.

GABBAY, Y. B.; HOMEM, V. S. F.; MUNFORD, V.; ALVES, A. S.; MASCARENHAS, J. D. P.; LINHARES, A. C.; RÁCZ, M. L. . Detection of rotavirus in dogs with diarrhea in Brazil. Brazilian J. Microbiol., v. 34, p. 77-80, 2003.

GABBAY, Y. B.; JIANG, B.; OLIVEIRA, C. S.; MASCARENHAS, J. D.; LEITE, J. P.; GLASS, R. I.; LINHARES, A. C. An outbreak of group C rotavirus gastroenteritis among children attending a day-care centre in Bélem, Brazil. J. Diarrhoeal Dis. Res., v. 17, p. 69-74, 1999.

GABBAY, Y. B.; LINHARES, A. C.; CAVALCANTE - PEPINO, E. L.; NAKAMURA, L. S.; OLIVEIRA, D. S.; DA SILVA, L. D.; MASCARENHAS, J. D.; OLIVEIRA, C. S.; MONTEIRO, T. A.; LEITE, J. P. Prevalence of human astrovirus genotypes associated with acute gastroenteritis among children in Bélem, Brazil. J. Med. Virol., v. 79, p. 530538, 2007.

GABBAY, Y. B.; MORAIS, M. A. A.; ALVES, A. S.;OLIVEIRA, K. K.; MASCARENHAS, J. D. P.; LINHARES, A. C. Rotavirus Detection by Immunochromatography : simple assay with a fast execution. Revista Paraense de Medicina, v. 19, p. 13-18, 2005.

GARBARG-CHENON, A.; BRICOUT, F.; NICOLAS, J. Serological characterization of human reassortant rotaviruses. J. Virol., v. 59, p. 510-513, 1986.

GATTI, M. S. V.; HARA, N. H.; FERRAZ, M. M. G.; PESTANA de Castro, A. F. Presence of group $A$ and non-A rotaviruses in neonatal piglets in Campinas, SP, Brazil. Med. Microbiol. Immunol., v. 178, p. 347-349, 1989. 
GATTI, M. S. V.; RICCI, L. C.; SERAFIM, M. B.; PESTANA DE CASTRO, A. F. . Incidência de Escherichia coli enterotoxigenica (ETEC), rotavírus e Clostidium perfringens de casos de diarréia em crianças, na região de Campinas, SP, Brasil. Rev. Inst. Med. Trop. São Paulo. v. 31, p. 392-398, 1989.

GAULT, E.; CHIKHI-BRACHET, R.; DELON, S.; SCHNEPF, N.; ALBIGES, L.; GRIMPREL, E.; GIRARDET, J. F.; BEGUE, P.;; GARBARG-CHENON, A. Distribution of human rotavirus $G$ types circulating in Paris, France, during the 1997-1998 epidemic high prevalence of type G4. J. Clin. Microbiol., v. 37, p. 2373-2375, 1999.

GENTSCH, J. R.; GLASS, R. I.; WOODS, P.; GOUVEA, V.; GORZIGLIA, M.; FLORES, J.; DAS. BIMAL, K.; BHAN, M. K. Identification of group A rotavirus gene 4 types by polymerase chain reaction. J. Clin. Microbiol., v. 30 p. 1365-1373, 1992.

GENTSCH, J. R.; LAIRD, A. R.; BIELFELT, B.; GRIFFIN, D. D.; BANYAI, K.; RAMACHANDRAN, M.; JAIN V.; CUNLIFFE, N. A.; NAKAGOMI, O.; KIRKWOOD, C. D.; FISCHER, T. K.; PARASHAR, U. D.; BRESEE, J. S.; JIANG, B.; GLASS, R. I. Serotype diversity and reassortment between human and animal rotavirus strains: implications for rotavirus vaccine programs. J Infect Dis., v. 192, p. S146-159, 2005, Suppl 1.

GENTSCH, J. R.; WOOD, P. A.; RAMACHANDRAN, M.; DAS, B. K.; LEITE, J. P.; ALFIERI, A. A.; KUMAR, R.; BHAN, M. K.; GLASS, R. I . Review of G and P typing results from a global collection of rotavirus strains: implications for vaccine development. J. Infect. Dis., v. 174, p. 30-36, 1996, suppl 1.

GILGER, M. A.; MATSON, D. O.; CONNER, M. E.; ROSENBLATT, H. M.; Finegold, M. J.;. Estes, M. K. Extra intestinal rotavirus infections in children with immunodeficiency. $\mathbf{J}$. Pediatr., v. 120, p. 912-917, 1992.

GIORDANO, M. O.; FERREYRA, L.; ISA, M. B.; MARTINEZ, L. C.; YUDOWSKY, S. I.; NATES, S. V. The epidemiology of acute viral gastroenteritis in hospitalized children in Cordoba city, Argentina: an insight of disease burden. Rev. Inst. Med. Trop. São Paulo, v. 43, p. 193-197, 2001.

GLASS, R. I.; BRESEE, J. S.; TURCIOS, R.; FISCHER, T. K.; PARASHAR, U. D.; STEELE, A. D. Rotavirus vaccines: targeting the developing world. J Infect Dis. 2005 Sep 1;192 Suppl 1:S160-6. PMID: 16088799 [PubMed - indexed for MEDLINE]

GLASS, R. I.; PARASHAR, U. D. The promise of new rotavirus vaccines. N Engl $\mathbf{J}$. Med., v. 354, p. 75-77, 2006.

GLEIZES, O.; DESSELBERGER, U.; TATOCHENKO V.; RODRIGO C.; SALMAN, N.; MEZNER, Z.; GIAQUINTO, C.; GRIMPREL, E. Nosocomial rotavirus infection in European countries: a review of the epidemiology, severity and economic burden of hospital-acquired rotavirus disease. Pediatr. Infect. Dis. J., p. S12-21, 2006, Suppl. 1.

GOMBOLD, J. L.; RAMIG, R. F. Genetics of the rotaviruses. In: Rotaviruses, edited by R. F. Ramig, Berlin:Springer-Verlag, 1994, p. 130-177. 
GONZALEZ, R. A.; ESPINOSA, R.; ROMERO, P.; LOPEZ, S.; ARIAS, C. F. Relative localization of viroplasmic and endoplasmic reticulum-resident rotavirus proteins in infected cells. Arch. Virol., v. 145, p. 1963-1973, 2000.

GOUVEA, V.; CASTRO, L.; TIMENETSKY, M. C.; GREENBERG, H. B.; SANTOS, N. Rotavirus serotype $\mathrm{G} 5$ associated with diarrhea in Brazilian children. J. Clin. Microbiol., v. 5, p. 1408-1409, 1994.

GOUVEA, V.; GLASS, R. I.; WOODS, P.; TANIGUCHI, K.; CLARK, H. F.; FORRESTER, B.; FANG, Z. Polymerase chain reaction amplification and typing of rotavirus nucleic acid from stool specimens. J. Clin. Microbiol., v. 28, p. 276-282, 1990.

GOUVEA, V.; SANTOS, N.; TIMENETSKY. M. C. Identification of bovine and porcine rotavirus G types by PCR. J. Clin. Microbiol., v. 32, p. 1338-1340, 1994.

GOUVEA, V.; SANTOS, N.; TIMENETSKY. M. C. VP4 typing of bovine and porcine group A rotaviruses by PCR. J. Clin. Microbiol., v. 32, p. 1333-1337, 1994.

GRAHAM, D. Y.; ESTES, M. K . Proteolytic enhancement of rotavirus infectivity: biologics mechanisms. Virology, v. 101, p. 432-439, 1980.

GRAHAM, D. Y.; ESTES, M. K. Pathogenesis and treatment of rotavirus diarrhea. Gastroenterology, v. 101, p. 1140-1141, 1991.

GREENBERG, H.; MCAULIFFE, V.; VALDESUSO, J.; WYATT, R.; FLORES, J.; KALICA, A.; HOSHINO, Y.; SINGH, N. Serological analysis of the subgroup protein of rotavirus using monoclonal antibodies. Infect. Immun., v. 39, p. 91-99, 1983.

HERRING, A. J.; INGLIS, N. F.; OJEH, C. K.; SNODGRASS, D. R.; MENZIES, J. D. Rapid diagnosis of rotavirus infection by direct detection of viral nucleic acid in silverstained Polyacrylamide gels. J. Clin. Microbiol., v. 16, p. 473-477, 1982

HJELT, K.; GRAUBALLE, P. C.; PAERREGAARD A.; NIELSEN, O. H.; KRASILNIKOFF, $P$. A. Protective effect of preexisting rotavirus-specific immunoglobulin $A$ against naturally acquired rotavirus infection in children. J Med Virol., v. 21, p. 39-47, 1987.

HOCHWALD, C.; KIVELA, L. Rotavirus vaccine, live, oral, tetravalent (RotaShield). Pediatr. Nurs., v. 25, p. 203-204, 207. 1999.

HOSHINO, Y.; GORZIGLIA, M.; VALDESUNO, J.; ASKAA, J.; GLASS, R. I.; KAPIKIAN, A. Z. An equine rotavirus (FI-14 strain) which bears both subgroup I and subgroup II specificities on its VP6. Virology, v. 157, p. 488-496, 1987.

HOSHINO, Y.; KAPIKIAN, A. Z. Rotavirus antigens. In: Rotaviruses. Ed. R. F. Ramig. Berlin, Springer - Verlag, 1994. p. 180-227.

HOSHINO, Y.; SAIF, L. J.; SERENO, M. M.; CHANOCK, R. M.; KAPIKIAN, A. Z. Infection immunity of piglets to either VP3 or VP7 outer capsid protein confers resistance to challenge with a virulent rotavirus bearing the corresponding antigen. J. Virol., v. 62, p. 744-748, 1988. 
HOULY, C. A. P.; UCHOA, M. M. M.; ZAIDAN, A. M. E.; GOMES-NETO, A.; DEOLIVEIRA, F. M.; ATHAYDE, M. A. G.; ALMEIDA, M. F. L. M.; PEREIRA, H. G. Electrophoretic study of the genome of human rotavirus from Maceio, Brazil. Brazilian $\mathbf{J}$. Med. Biol. Res., v. 19, p. 33-37, 1986.

HUANG, H.; SCHROEDER, F; ZENG, C.; ESTES, M. K.; SCHOER, J. K.; BALL, J. M. Membrane interactions of a novel viral enterotoxin: rotavirus nonstructural glycoprotein NSP4. Biochemistry, v. 40, p. 4169-4180, 2001.

INSTITUTO ADOLFO LUTZ E CENTRO DE VIGILÂNCIA EPIDEMIOLÓGICA "Professor Alexandre Vranjac". Informes técnicos institucionais: Diarréia e rotavírus. Rev. Saúde. Publ. São Paulo. v. 38, p. 844-845, 2004.

ITURRIZA GOMARA, M.; WONG, C.; BLOME, S.; DESSELBERGER, U.; GRAY, J. Rotavirus subgroup characterisation by restriction endonuclease digestion of a cDNA fragment of the VP6 gene. J. Virol Methods, v. 105, p. 99-103, 2002.

ITURRIZA-GOMARA, M.; ISHERWOOD, B.; DESSELBERGER, U.; GRAY, J. Reassortment in vivo: driving force for diversity of human rotavirus strains isolated in the United Kigdom between 1995 and 1999. J. Virol., v. 75, p. 3696-3705, 2001.

ITURRIZA-GÓMARA, M.; WONG, C.; BLOME, S.; DESSELBERGER, U.; GRAY, J. Molecular characterization of VP6 genes of human rotavirus isolates: correlation of genogroups with subgroups and evidence of independent segregation. J. Virol., v. 76, p. 6596-6601, 2002.

JAIN, V.; DAS, B. K.; BHAN, M. K.; GLASS, R. I.; GENTSCH, J. R. The Indian strains surveillance collaborating laboratories. Great diversity of group A rotavirus strains and high prevalence of mixed rotavirus infection in India. J. Clin. Microbiol., v. 39, p. 35243529, 2001.

JAMES, V. L. A.; LAMBDEN, P. R.; CAUL, E. O.; CLARKE, I. N. . Enzyme-linked immunosorbent assay based on recombinant human group $C$ rotavirus inner capsid protein (VP6) to detect human group $\mathrm{C}$ rotaviruses in fecal samples. J. Clin. Microbiol., v. 36, p. 3178-3181, 1998.

JAYARAM H.; ESTES, M. K.; PRASAD, B. V. Emerging themes in rotavirus cell entry, genome organization, transcription and replication. Virus Res., v. 101, p. 67-81, 2004.

JIANG B.; WANG Y.; GLASS, R. I.; FANG, Z. Y. The evolution of human group B rotaviruses: correction and an update. J. Clin. Virol., v. 34, p. 158-159, 2005.

JOURDAN, N.; BRUNET, J. P.; SAPIN, C.; BLAIS, A.; COTTE-LAFFITTE, J.; FORESTIER, F.; QUERO, A. M.; TRUGNAN, G.; SERVIN, A. L. Rotavirus infection reduces sucrase-isomaltase espression in human intestinal epithelial cels by perturbing protein trangeting and organization of microvillar cytoskeleton. J. Virol., v. 72, p. 72287236, 1998.

KANE, E. M.; TURCIOS, R. M.; ARVAY, M. L.; GARCIA, S.; BRESEE, J. S.; GLASS, R. I. The epidemiology of rotavirus diarrhea in Latin America. Anticipating rotavirus vaccines. Rev. Panam. Salud. Publica., v. 16, p. 371-377, 2004. 
KANG, G. Rotavirus vaccines. Indian. J. Med. Microbiol., v. 24, p. 252-257, 2006.

KAPIKIAN, A. Z.; WYATT, R. G.; DOLIN, R.; THORNHILL, T. S.; KALICA, A. R.; CHANOCK, R. M. Visualization by immune electron microscopy of a $27 \mathrm{~nm}$ particle associated with acute infections nonbacterial gastroenteritis. J. Virol., v. 10, p. 10751081, 1972.

KELKAR, S. D.; ZADE, J. K. Group B rotaviruses similar to strain CAL-1, have been circulating in Western India since 1993. Epidemiol. Infect., v. 132, p. 745-749, 2004.

KOBAYASHI, N.; NAIK, T. N.; KUSUHARA, Y.; KRISHNAN, T; SEN, A.; BHATTACHARYA, S. K.; TANIGUCHI, K.; ALAM, M. M.; URASAWA, T.; URASAWA, S. Sequence analysis of genes encoding structural and nonstructural proteins of a human group B rotavirus detected in Calcutta, India. J. Med. Virol., v. 64, p. 583-588, 2001.

LANDAETA, M. E.; DOVE, W.; VINH, H.; CUNLIFFE, N. A.; CAMPBELL, J.; PARRY, C. M.; FARRAA, J. J.; HART, C. A. Characterization of rotavirus causing diarrhoea invietnamesse children. Ann. Trop. Parasitol, v. 97, p. 53-59, 2003.

LAWTON, J. A.; ZENG, C. Q. Y.; MUKHERJEE, S. K.; COHEN, J.;. ESTES, M. K.; PRASAD, B. V. V. Three-dimensional structural analysis of recombinant rotavirus-like particles with intact and amino-terminal-deleted VP2: implications for the architecture of the VP2 capside layer. J. Virol., v. 71, p. 7353-7360, 1997.

LEITE, J. P.; ALFIERI, A. A.; WOODS, P.; GLASS, R. I.; GENTSCH, J. R. . Rotavirus G and $P$ types circulating in Brazil: characterization by RT-PCR, probe hybridization, and sequence analysis. Arch Virol., v. 141, p. 2365-2374, 1996.

LIGHT, J. S.; HODES, H. L. Studies on epidemic diarrhea of the newborn: isolation pf a filtrable agent causing diarrhea in calves. Am. J. Public Health, v. 33, p. 1451-1454, 1943.

LIJIMA, Y.; IWAMOTO, T.; NUKUZUMA, S.; OHISHI, H.; HAYASHI, K.; KOBAYASHI, N. An outbreak of rotavirus infection among adults in an institution for rehabilitation: longterm residence in a closed community as a risk factor for rotavirus illness. Scand. J. Infect. Dis., v. 38, p. 490-496, 2006.

LINHARES, A. C.; BRESEE, J. S. Rotavirus vaccines and vaccination in Latin America. Pan Am J Public Health, v. 8, p. 305-331, 2000.

LINHARES, A. C.; GABBAY, Y. B.; MASCARENHAS, J. D. P.; FREITAS, R. B.; FLEWETT, T. H.; BEARDS G. M. Epidemiology of rotavirus subgroups and serotypes in Bélem, Brazil: a three-year study. Ann. Inst. Pasteur. Virol. v. 139, p. 89-99, 1988.

LINHARES, A. C.; MASCARENHAS, J. D.; GUSMÃO, R. H.; GABBAY, Y. B.; FIALHO, A. M.; LEITE, J. P. Neonatal rotavirus infection in Bélem, northern Brazil: nosocomial transmission of a P[6] G2 strain. J. Med. Virol., v. 67, p. 418-426, 2002.

LiNhARES, A. C.; PINHEIRO, F. P.; SChMETZ, C.; MULleR, G.; PETERS, D. Duovírus (rotavírus) em Belém do Pará, Brasil. Rev. Inst. Med. Trop., São Paulo, v. 19, p. $278279,1977$. 
LINHARES, A.C. Epidemiologia das infecções por rotavírus no Brasil e os desafios para o seu controle. Cad. Saúde. Pública, v. 16, p. 629-646, 2000.

LIPRANDI, F.; LOPEZ, G. R.; HIDALGO, M.; LUDERT, J. E.; MATTION, N. Monoclonal antibodies to the VP6 of porcine subgroup I rotaviruses reactive with subgroup I and non-subgroup I non- subgroup II strains. J. Gen. Virol., v. 71, p. 1395-1398, 1990.

LIU, M.; OFFIT, P. A.; ESTES, M. K. Identification of the simian rotavirus SA11 genome segment 3 product. Virology, v. 163, p. 26-32, 1988.

LOGAN, C.; O'LEARY, J. J.; O'SULLIVAN, N. Real-Time Reverse Transcription-PCR for Detection of Rotavirus and Adenovirus as Causative Agents of Acute Viral Gastroenteritis in Children. J. Clin. Microbiol., v. 44, p. 3189-3195, 2006.

LOURENÇO, M. H.; NICOLAS, J. C.; COHEN, J.; SCHERRER, R.; BRICOUT, F. Study of human rotavirus genome by electrophoresis: attempt of classification among strains isolated in France. Ann. Inst. Pasteur/Virol., v. 132, p. 161-173, 1981.

LYNCH M.; BRESEE, J. S.; GENTSCH, J. R.; GLASS, R. I. Rotavirus vaccines. Curr Opin Infect Dis., v. 13, p. 495-502, 2000.

LYNCH, M.; SHIEH, W. J.; BRESEE, J. S.; TATTI, K. M.; GENTSCH, J. R.; JONES, T.; JIANG, B.; HUMMELMAN, E.; ZIMMERMAN, C. M.; ZAKI, S. R.; GLASS, R. I. Intussusception after administration of the rhesus tetravalent rotavirusvaccine (Rotashield): the search for a pathogenic mechanism. Pediatrics., v. 117, p. e827-32, 2006.

MARTELLA, V.; CIARLET, M.; BASELGA, R.; ARISTA, S.; ELIA, G.; LORUSSO, E.; BANYAI, K.; TERIO, V.; MADIO, A.; RUGGERI, F. M.; FALCONE, E.; CAMERO, M.; DECARO, N.; BUONAVOGLIA, C. Sequence analysis of the VP7 and VP4 genes identifies a novel VP7 gene allele of porcine rotaviruses, sharing a common evolutionary origin with human G2 rotaviruses. Virology., v. 337, p. 111-123, 2005.

MARTELLA, V.; CIARLET, M.; LAVAZZA, A.; CAMARDA, A.; LORUSSO, E.; TERIO, V.; RICCI, D.; CARIOLA, F.; GENTILE, M.; CAVALLI, A.; CAMERO, M.; DECARO, N.; BUONAVOGLIA, C. Lapine rotaviruses of the genotype $P[22]$ are widespread in Italian rabbitries. Vet Microbiol., v. 111, p. 117-24, 2005.

MASCARENHAS, J. D. P., GUSMÃO, R. H. P.; GABBAY, Y. B.; MONTEIRO, T. A. F.; GOMES, B. R.; LINHARES A. C. Concomitant rotavirus serotypes 1 and 4 infections a diarrheic child from Bélem, Brazil. Rev. Inst. Med. Trop. São Paulo. 38 (4): 249-252, 1996.

MASCARENHAS, J. O. P.; LINHARES, A. C.; GABBAY, Y. B.; DE FREITAS, R. B.; MENDES, E.; LOPES, S.; ARIAS, C. F. Naturally occurring serotype 2/subgroup II rotavirus reassortants in northern Brazil. Virus Res., v. 14, p. 235-240, 1989.

MASON, B. B.; GRAHAM, D. Y.; ESTES, M. K. Biochemical mapping of the simian rotavirus SA11 genome. J. Virol., v. 46, p. 413-23, 1983. 
MATTHEWS, R. E. F. Classification and nomenclature of viruses. Third report of the International Committee on Taxonomy of Viruses, Basel:Karger, 1979.

MATTION, N. M.; COHEN, J.; APONTE, C.; ESTES, M. K. Characterization of an oligomerization domain and RNA-binding properties on rotavirus nonstructural protein NS34. Virology., v. 190,, p. 68-83, 1992.

MATTION, N. M.; MITCHELL, D. B.; BOTH, G. W.; ESTES MK. Expression of rotavirus proteins encoded by alternative open reading frames of genome segment 11 . Virology., v. 181, p. 295-304, 1991.

MAUNULA, L.; VON BONSDORFF, C. H. Frequent reassortments may explain the genetic heterogeneityof rotaviruses: analysis of finnish rotavirus strains. J. Virol., v. 76, p. 11793-11800, 2002.

MAUNULA, L.; VON BONSDORFF, C. H. . Short sequences define genetic lineages: phylogenetic analysis of group A rotaviruses based on partial sequences of genome segments 4 and 9. J. Gen. Virol., v. 79, p. 321-332, 1998.

MCCRAE, M. A. Nucleic acid-based analyses of non-group A rotavirus. In: Novel diarrhoea viruses. Chinchester, UK, John. Wiley \& Sons, 1987. p. 24-48.

MEBUS, C. A.; UNDERDAHL, N. R.; RHODES, M. B.;TWIEHAUS, M. J. Calf diarrhea (scours) reproduced with a virus from a field outbreak. Nebraska Agric. Exp. St. Bul. v. 233, p. 1-16, 1969.

MINISTÉRIO DA SAÚDE. Informação sobre o Programa Nacional de Vacinação. disponível em: http://portal.saude.gov.br/saude/ . Acesso em: 25 abril 2007.

MIR, K. D.; PARR, R. D.; SCHROEDER, F.; BALL, J. M. Rotavirus NSP4 interacts with both the amino- and carboxyl-termini of caveolin-1. Virus Research. 2007, In press.

MONTENEGRO, F. M.; CORREIA, J. B.; RODRIGUES, F. A.; DOVE, W.; NAKAGOMI, T.; NAKAGOMI, O.; CUEVAS, L. E.; CUNLIFFE, N. A.; HART, C. A. Anticipating rotavirus vaccines in Brazil: detection and molecular characterization of emerging rotavirus serotypes G8 and G9 among children with diarrhea in Recife, Brazil. J. Med. Virol., v. 79, p. 335-340, 2007.

MULLER, H.; JOHNE, R. Rotaviruses: diversity and zoonotic potential--a brief review. Berl Munch Tierarztl Wochenschr., v. 120, p. 108-112, 2007.

MURPHY, T. V.; GARGIULLO, P. M.; MASSOUDI, M. S.; NELSON, D. B.; JUMAAN, A. O.; OKORO, C. A.; ZANARDI, L. R.; SETIA, S.; FAIR, E.; LEBARON, C. W.; WHARTON, M.; LIVENGOOD, J. R. Intussusception among infants given an oral rotavirus vaccine. N Engl J. Med ., v. 344, p. 564-572, 2001.

MWENDA, J. M.; PEENZE, I.; OMOLLO, E.; GALO, M.; STEELE, A. D. Human group C rotaviruses identified in Kenya. East Afr Med J., v. 80, p. 73-76, 2003. 
NAKAGOMI, O.; ISEGAWA, Y.; HOSHINO, Y.; ABOUDY, Y.; SHIF, I.; SILBERSTEIN, I.; NAKAGOMI, T.; UEDA, S.; SEARS, J.; FLORES, J. A new serotype of the outer capsid protein VP4 shared by an unusual human rotavirus strain Ro1845 and canine rotaviruses. J. Gen. Virol., v. 74, p. 2771-2774, 1993.

NAKAGOMI, $T$. Rotavirus infection and intussusception:a view from retrospect. Microbiol. Immunol., v. 44, p. 619-628, 2000.

NAKAGOMI, T.; MATSUDA, Y.; OHSHIMA, A.; MOCHIZUKI, M.; NAKAGOMI, O. Characterization of a canine rotavirus strain by neutralization and molecular hybridization assays. Arch. Virol., v. 106, p. 145-150, 1989.

NAKATA, S.; ESTES M. K.; GRAHAM, D. Y.; LOOSLE, R.; TAO, H.; WANG, S. H.; SAIF, L. J.; MELNICK, J. L. Antigenic characterization and ELISA detection of adult diarrhea rotaviruses. J. Infect. Dis., v. 154, p. 448-455, 1986.

NILSSON, M.; SVENUNGSSON, B.; HEDLUND, K. O.; UHNOO, I.; LAGERGREN, A.; AKRE, T.; SVENSSON, L. Incidence and genetic diversity of group $C$ rotavirus among adults. J. Infect. Dis., v. 182, p. 678-684, 2000.

OFFIT, P. A. Host factors associated with protection against rotavirus disease: the skies are clearing. J. Infect. Dis., v. 174 (suppl 1), p. S59-S64, 1996.

OFFIT, P. A.; BLAVAT, $G$. Identification of the two rotavirus genes determining neutralization specificities. J. Virol., v. 57, p. 376-378, 1986.

O'RYAN, M.; PEREZ-SCHAEL, I.; MAMANI, N.; PENA, A.; SALINAS, B.; GONZALEZ, G.; GONZALEZ, F.; MATSON, D. O.; Gomez, J. . Rotavirus - associated medical visits and hospitalization in South America: a prospective study at three large sentinel hospitals. Pediatic. Infect. Dis. J., v. 20, p. 685-693, 2001.

O'RYAN, M.; PEREZ-SCHAEL, I.; MAMANI, N.; PENA, A.; SALINAS, B.; GONZALEZ, G.; GONZALEZ, F.; MATSON, D. O.; GOMEZ, J. Rotavirus-associated medical visits and hospitalizations in South America: a prospective study at three large sentinel hospitals. Pediatric Infec. Dis. J., v. 20, p. 685-693, 2001.

PALOMBO, E. A . Genetic analysis of Group A rotaviruses: Evidence for interspecies transmission of rotavirus genes. Virus Genes, v. 24, p. 11-20, 2002.

PALOMBO, E. A.; MASENDYCZ, P. J.; BUGG, H. C.; BOGDANOVIC-SAKRAN, N.; BARNES, G. L.; BISHOP, R. F. Emergence of serotype G9 human rotaviruses in Australia. J. Clin. Microbiol., v. 38, p. 1305-1306, 2000.

PANG, X. L.; LEE, B.; BOROUMAND, N.; LEBLANC, B.; PREIKSAITIS, J. K.; YU, C. C. Increased detection of rotavirus using a real time reverse transcription-polymerase chain reaction (RT-PCR) assay in stool specimens from children with diarrhea. J. Med. Virol., v. 72, p. 496-501, 2004.

PARASHAR U. D.; HUMMELMAN E. G.; BRESEE J. S.; MILLER M. A.; GLASS R. I. Global illness and deaths caused by rotavirus disease in children. Emerg. Infect. Dis., v. 9, p. 565-572, 2003. 
PARRA, G. I.; BOK, K.; MARTINEZ, V.; RUSSOMANDO, G.; GÓMEZ, J. Molecular characterization and genetic variation of the VP7 gene of human rotaviruses isolated in Paraguay. J. Med. Virol., v. 77, p. 579-586, 2005.

PARRE, V.; BOK, K.; FERNANDEZ, F.; GOMEZ, J. Molecular characterization of the first isolation of rotavirus in guanacos (Lama guanicoe). Arch Virol., v. 149, p. 24652471, 2004.

PARWANI, A. V.; HUSSEIN, H. A.; ROSEN, B. I.; LUCCHELLI, A.; NAVARRO, L.; SAIF, L. J. Characterization of field strains of group $A$ bovine rotaviruses by using polymerase chain reaction-generated $\mathrm{G}$ and $\mathrm{P}$ type-specific cDNA probes. J. Clin. Microbiol., v. 31, p. 2010-2015, 1993.

PATTON, J. T.; CHNAIDERMAN, J.; SPENCER, E. Open reading frame in rotavirus mRNA specifically promotes synthesis of double-stranded RNA: template size also affects replication efficiency. Virology, v. 264, p. 167-180, 1999.

PATTON, J. T.; SPENCER E. Genome replication and packaging of segmented doublestranded RNA viruses. Virology, v. 277, p. 217-225, 2000.

PATTON, J. T.; VASQUEZ-DEL CARPIO, R.; SPENCER E. Replication and transcription of the rotavirus genome. Curr Pharm Des., v. 10 p. 3769-3777, 2004.

PAUL, P. S.; LYOO, Y. S. Immunogens of rotaviruses. Vet Microbiol., v.37, p. 299-317, 1993.

PEREIRA, H. G.; AZEREDO, R. S.; LEITE, J. P. G.; ANDRADE, Z. P.; CASTRO, L. . A combined enzyme immunoassay for rotavirus and adenovirus. J. Virol. Meth., v. 10, p. 21-28, 1985.

PEREIRA, H. G.; AZEREDO, R. S.; LEITE, J. P. G.; CANDEIAS, J. A. N.; RÁCZ, M. L.; LINHARES, A. C.; GABBAY, Y. B.; TRABULSI, L. R. Electrophoretic study of the genome of human rotaviruses from Rio de Janeiro, Sao Paulo and Pará, Brazil. J. Hyg., Camb., v. 90, p. 117-125, 1983.

PEREZ, J. F.; RUIIZ, M.; CHEMELLO, M. E; MICHELANGELI F. Characterization of a membrane calcium pathway induced by rotavirus infection in cultured cells. J. Virol., v. 73 p. 2481-2490, 1999.

PEREZ-SCHAEL, I.; GUNTINAS, M. J.; PEREZ, M.; PAGONE, V.; ROJAS, A. M.; GONZALEZ, R.; CUNTO, W.; HOSHINO, Y.; KAPIKIAN, A. Z. . Efficacy of the rhesus rotavirus-based quadrivalent vaccine in infants and young children in Venezuela. $\mathbf{N}$ Engl J. Med ., v. 337, p. 1181-1187, 1997.

PETER, G.; MYERS, M. G.; National Vaccine Advisory Committee; National Vaccine Program Office. Intussusception, rotavirus, and oral vaccines: summary of a workshop. Pediatrics., V. 110, p. e67, 2002. 
PHAN, T. G.; NISHIMURA, S.; OKAME, M.; NGUYEN, T. A.; KHAMRIN, P.; OKITSU, S.; MANEEKARN, N.; USHIJIMA, H. Virus diversity and an outbreak of group $\mathrm{C}$ rotavirus among infants and children with diarrhea in Maizuru city, Japan during 2002-2003. J. Med. Virol., v. 74, p. 173-179, 2004.

PIETRUCHINSKI, E; BENATI, F; LAURETTI, F.; KISIELIUS, J.; UEDA, M.; VOLOTAO, E. M.; SOARES, C. C.; HOSHINO, Y.; LINHARES, R. E.; NOZAWA, C.; SANTOS, N. Rotavirus diarrhea in children and adults in a southern city of Brazil in 2003: Distribution of G/P types and finding of a rare G12 strain. J. Med. Virol., v. 78, p. 1241-1249, 2006.

PISANELLI, G.; MARTELLA, V.; PAGNINI, U.; DE MARTINO, L.; LORUSSO, E.; IOVANE, G.; BUONAVOGLIA, C. Distribution of G (VP7) and P (VP4) genotypes in buffalo group A rotaviruses isolated in Southern Italy. Vet Microbiol., v. 110, p. 1-6, 2005.

PRASAD, B. V. V.; BURNS, J. W.; MARIETTA, E.; ESTES, M. K.; CHIU, W. Localization of VP4 neutralization sites in rotavirus by three-dimensional cryo-electron microscopy. Nature v. 343, p. 476-479, 1990.

PRASAD, B. V. V.; CHIU, W. Structure of rotaviruses. In: Rotaviruses, edited by R. F. Ramig, Berlin:Springer-Verlag, p. 9-29, 1994.

PRASAD, B. V. V.; ROTHNAGEL, R.; ZENG, C. Q. Y.; JAKANA, J.; LAWTON, J. A.; CHIU, W.; ESTES, M. K. Visualization of ordered genomic RNA and location of transcriptonal complexes in rotavirus. Nature, v. 382, p. 471-473, 1996.

QIAN, Y.; GREEN, K. Y. Human rotavirus strain 69M has a unique VP4 as determined by amino acid sequence analysis. Virology, v.182, p. 407-412, 1991.

RÁCZ, M. L.; CANDEIAS, J. A. N.; TRABULSI, L. R.; MURAHOWSKY, J. . Diarrheal diseases in Brazil: clinical features of rotavirus- associated gastroenteritis in children. Eur. J. Epidemiol., v. 4, p. 382-385, 1988.

RÁCZ, M. L.; KROEFF, S. S.; MUNFORD, V.; CARUZO, T. A. R.; DURIGON, E. L.; HAYASHI, Y.; GOUVEA, V.; PALOMBO, E. A. Molecular characterization of porcine rotaviruses from the southern region of Brazil: characterization of an atypical genotype G(9) strain. J. Clin. Microbiol., v. 38, p. 2443-2446, 2000.

RÁCZ, M. L.; KROEFF, S. S.; MUNFORD, V.; CARUZO, T. A. R.; DURIGON, E. L.; HAYASHI, Y.; GOUVEA, V.; PALOMBO, E. A . Molecular characterization of porcine rotaviruses from the southern region of Brazil: characterization of an atypical genotype G9 strain. J. Clin. Microbiol., v. 38, p. 2443-2446, 2000.

RÁCZ, M. L.; MUNFORD, V.; FERNANDES, M. J. B.; KROEFF, S. S.; KOTAIT, I. Identification, propagation and subgroup characterization of an equine rotavirus isolated in Sao Paulo, Brazil. Rev. Microbiol. São Paulo., v. 24, p. 161-165, 1993.

RAHMAN, M.; BANIK, S.; FARUQUE, A. S. G.; TANIGUCHI, K.; SACK, D. A.; VAN RANST, M.; AZIM, T. Detection and Characterization of Human Group C Rotaviruses in Bangladesh. J. Clin. Microbiol., v. 43, p. 4460-4465, 2005. 
RAHMAN, M.; BANIK, S.; FARUQUE, A. S.; TANIGUCHI, K.; SACK, D. A.; VAN RANST, M.; AZIM, T. Detection and characterization of human group $C$ rotaviruses in Bangladesh. J. Clin. Microbiol., v. 43, p. 4460-4465, 2005.

RAMACHANDRAN, M.; DAS, B. K.; VIJ, A.; KUMAR, R.; BHAMBAL, S. S.; KESARI, N.; RAWAT, H.; BAHL, L.; THAKUR, S.; WOODS, P. A.; GLASS, R. I.; BHAN, M. K.; GENTSCH J. R. Unusual diversity of human rotavirus $G$ and $P$ genotypes in India. $\mathbf{J}$. Clin. Microbiol. v. 34, p. 436-439, 1996.

RAMIG, R. F. Pathogenesis of intestinal and systemic rotavirus infection. J. Virol., v. 78, p. 10213-10220, 2004.

RAMIG, R. F. Pathogenesis of intestinal and systemic rotavirus infection. J. Virol., v. 78, p. 10213-10220, 2004.

REIDY, N.; LENNON, G.; FANNING, S.; POWER, E.; O'SHEA, H. Molecular characterization and analysis of bovine rotavirus strains circulating in Ireland 2002-2004. Vet Microbiol., v. 31, p 242-247, 2006.

RENNELS, M. B., PARASHAR; U. D., HOLMAN; R. C; LE, C. T; CHANG, H. G; GLASS, R. I. Lack of an apparent association between intussusception and wild or vaccine rotavirus infection. Pediatr. Infect. Dis. J., v. 17, p. 924-925, 1998.

RENNELS, M. B.; GLASS, R. I.; DENNEHY, P. H.; BERNSTEIN, D. I.; PICHICHERO, M. E.; ZITO, E. T.; MACK, M. E.; DAVIDSON, B. L.; KAPIKIAN, A. Z. Safety and efficacy of high-dose rhesus-human reassortant rotavirus vaccines--report of the National Multicenter Trial. United States Rotavirus Vaccine Efficacy Group. Pediatrics, v. 97, p. 7-13, 1996.

ROSA E SILVA, M. L., CARVALHO, I. P.; GOUVEA, V. 1998-1999 rotavirus seasons in Juiz de Fora, Minas Gerais, Brazil: Detection of Unusual G3P[4] Epidemic Strain. J. Clin. Microbiol., v. 40, p. 2837-2842, 2002.

ROSA E SILVA, M. L.; NAVECA, F. G.; PIRES DE CARVALHO, I. Epidemiological aspects of rotavirus infections in Minas Gerais, Brazil. Braz. J. Infect. Dis., v. 5, p. 215222, 2001.

ROSETO, A.; CAVALIERI, F.; GUILLEMIN, M. C.; DIANOUX, L.; SITBON, M.; LEMA, F.; PERIES. Replication of an isolate of human rotavirus on human cells cultured in vitro:observation by electron microscopy. C R Seances Acad. Sci. III, v. 292, p. 187-90, 1981.

RUBILAR-ABREU, E.; HEDLUND, K. O.; SVENSSON, L.; MITTELHOLZER,C. Serotype G9 rotavirus infections in adults in Sweden. J. Clin. Microbiol., v. 43, p. 1374-1376, 2005.

SAIF, L. J.; JIANG, B. Nongroup A rotaviruses of humans and animals. In: Rotaviruses, edited by R. F. Ramig, Berlin:Springer-Verlag, 1994, p. 340-371.

SAIF, L. J.; JIANG, B. Nongroup A rotaviruses of humans and animals. in: Rotaviruses. Ed. R. F. Ramig. Berlin, Springer - Verlag, 1994. p. 340-71. 
SANCHEZ-FAUQUIER, A.; ROMAN, E.; COLOMINA, J.; WILHELMI, I.; GLASS, R. I.; JIANG, B. First detection of group $C$ rotavirus in children with acute diarrhea in Spain. Arch Virol. v. 148, p. 399-404, 2003.

SANTOS, N.; LIMA, R. C. C.; PEREIRA, C. F. A.; GOUVEA, V. Detecção de rotavírus atípicos em crianças com diarréia no Rio de Janeiro. News Lab., v. 32, p. 78-86, 1999a.

SANTOS, N.; LIMA, R. C.; NOZAWA, C. M.; LINHARES, R. E.; GOUVEA, V. Detection of porcine rotavirus type $\mathrm{G} 9$ and of a mixture of types $\mathrm{G} 1$ and $\mathrm{G} 5$ associated with Walike VP4 specificity: evidence for natural human-porcine genetic reassortment. J. Clin. Microbiol., v.37, p. 2734-2736, 1999.

SANTOS, N.; LIMA, R. C.; PEREIRA, C. F.; GOUVEA, V. Detection of rotavirus types G8 and G10 among Brazilian children with diarrhea. J. Clin. Microbiol. 1998 Sep;36(9):2727-9. Cox MJ, James VL, Azevedo RS, Massad E, Medley GF. Infection with group $\mathrm{C}$ rotavirus in a suburban community in Brazil. Trop. Med. Int. Health., v. 3, p. 891-895, 1998.

SANTOS, N.; SOARES, C. C.; VOLOTÃO, E. M.; ALBUQUERQUE M. C.; HOSHINO Y. Surveillance of rotavirus strains in Rio de Janeiro, Brazil, from 1997 to 1999. J. Clin. Microbiol., v. 41, p. 3399-3402, 2003.

SANTOS, N.; VOLOTÃO, E. M.; SOARES, C. C.; ALBUQUERQUE, M. C. M.; SILVA, F. M.; CARVALHO, T. R. B.; PEREIRA, C. F. A.; CHIZHIKOV, V.; HOSHINO, Y. . Rotavirus strains bearding genotype $\mathrm{G} 9$ or $\mathrm{P}[9]$ recovered from Brazilian children with diarrhea from 1997 to 1999. J. Clin. Microbiol., v. 39, p. 1157-1160, 2001.

SANTOS, N.; VOLOTÃO, E. M.; SOARES, C. C.; ALBUQUERQUE, M. C. M.; SILVA, F. M.; CHIZHIKOV, V.; HOSHINO, Y. VP7 gene polymorphism of serotype G9 rotavirus strains and its impact on G genotype determination by PCR. Virus Res., v. 90, p. 1-14, 2002.

SCHNACK, F. J.; FONTANA, L. M.; BARBOSA, P. R.; Silva, L. S.; Baillargeon, C. M.; Barichello, T.; Povoa, M. M.; Cavasini, C. E.; Machado, R. L. Enteropathogens associated with diarrheal disease in infants ( $<5$ years old) in a population sample in Greater Metropolitan Criciúma, Santa Catarina State, Brazil. Cad. Saúde Pública., v. 19, p. 1205-1208, 2003.

SCHNAGL, R. D.; BONIFACE, K.; CARDWELL, P.; MCCARTHY, D.; ONDRACEK, C.; COULSON, B.; ERLICH, J.; MOREY, F. Incidence of group $\mathrm{C}$ human rotavirus in central Australia and sequence variation of the VP7 and VP4 genes. J. Clin. Microbiol., v. 42, p. 2127-2133, 2004.

SHAW, A. L.; ROTHNAGEL, R.; CHEN, D.; RAMIG, R. F.; CHIU, W.; PRASAD, B. V. V. 3-dimensional visualization of the rotavirus hemagglutinin structure. Cell, v. 74, p. 693701, 1993.

SHINOZAKI, K.; OKADA, M.; NAGASHIMA, S.; KAIHO, I.; TANIGUCHI, K. Characterization of human rotavirus strains with $\mathrm{G} 12$ and $P[9]$ detected in Japan. $\mathbf{J}$. Med. Virol., v. 73, p. 612-616, 2004. 
SILVESTRI, L. S.; TARAPOREWALA, Z. F.; PATTON, J. T. Rotavirus replication: plussense templates for double-stranded RNA synthesis are made in viroplasms. J. Virol., v. 78 p. 7763-7774, 2004.

SOUZA, D. F.; KISIELIUS, J. J.; UEDA, M.; GABBAY, Y. B.; CARMONA, R. C.; TIMENETSKY, M. C.; MASCARENHAS, J. D.; TAKIMOTO, S.; TANAKA, H. An outbreak of group $C$ rotavirus gastroenteritis among adults living in Valentim Gentil, São Paulo State, Brazil. J. Diarrhoeal. Dis. Res. v. 16, p. 59-65, 1998.

STEELE, A. D.; IVANOFF, B. Rotavirus strains circulating in Africa during 1996-1999: emergence of G9 strains and P[6] strains. Vaccine, v. 17;21, p. 361-367, 2003.

STEELE; A. D.; V. L. A. JAMES. Seroepidemiology of human group C rotavirus in South Africa. J. Clin. Microbiol., v. 37, p. 4142-4144, 1999.

STEWIEN, K. E.; MEHNERT, D. U.; HARSI, C. M.; STEWIEN, E. T. M.; CANDEIAS, J. M. G.; TANAKA, K. Serotype and eletropherotypes of human rotavirus detected in the city of São Luís (MA), Brazil. Brazilian J. Med. Biol. Res., v. 27, p. 1355-1361, 1994.

STEYER, A.; POLJSAK-PRIJATELJ, M.; BUFON, T.; SEDMAK, M.; VIDMAR, L.; MIJOVSKI, J. Z.; MARIN, J. First detection of group $C$ rotavirus in patients with gastroenteritis in Slovenia. J. Med. Virol., v. 78 p. 1250-1255, 2006.

SUZUKI, H.; CHEN, G. M.; HUNG, T.; BEARDS, G. M.; BROWN, D. W. G.; FLEWETT, T. H. . Effects of two negative staining methods on the chinese atypical rotavirus. Arch. Virol., v. 94, p. 305-308, 1987.

TANIGUCHI, K.; URASAWA, T.; MORITA, Y.; GREENBERG, H. B.; URASAWA, S. Direct serotyping of human rotavirus in stools by an enzyme-linked immunosorbent assay using serotype 1, 2, 3, and 4 specific monoclonal antibodies to VP7. J. Infect. Dis., v. 155, p. 1159-1166, 1987.

TARAPOREWALA, Z. F.; PATTON, J. T. Nonstructural proteins involved in genome packaging and replication of rotaviruses and other members of the Reoviridae. Virus Res., v. 101, p. 57-66, 2004.

TEIXEIRA, J. M.; CAMARA, G. N.; PIMENTEL, P. F.; FERREIRA, M. N.; FERREIRA, M. S.; ALFIERI, A. A.; GENTSCH, J. R.; LEITE, J. P. Human group C rotavirus in children with diarrhea in the Federal District, Brazil. Braz. J. Med. Biol. Res. v. 31, p. 1397-403, 1998.

The Universal Virus Database. ICTVdB -, version 4. .http://www. ncbi. nlm. nih. gov/ICTVdb/ICTVdB/ Microscopia eletônica de rotavírus disponível em http://www. ncbi. nlm. nih. gov/ICTVdb/ICTVdB/00. 060. 0. 03. 001. htm Acesso em : 20 abr. 2007.

THEIL, K. W.; MCCLOSKEY, C. M . Molecular epidemiology and subgroup determination of bovine group A rotaviruses associated with diarrhea in dairy and beef calves. J. Clin. Microbiol., v. 27, p. 126-131, 1989. 
TIMENETSKY, M. C.; KISIELIUS, J. J.; GRISI, S. J. F. E.; ESCOBAR, A. M. U.; UEDA, M.; TANAKA, H. Rotavírus, adenovirus, astrovirus, calicivirus e "small round virus particles" em fezes de crianças, com e sem diarréia aguda, no período de 1987 a 1988, na grande São Paulo. Rev.Inst.Med.Trop.,São Paulo, v. 35, p. 275-280, 1993.

TRABELSI, A.; PEENZE, I.; PAGER, C.; JEDDI, M.; STEELE, D. Distribution of rotavirus VP7 serotypes and VP4 genotypes circulating in Sousse, Tunisia, from 1995 to 1999: emergence of natural human reassortants. J. Clin. Microbiol., v. 38, p. 3415-3419, 2000.

VAN DER HEIDE, R.; KOOPMANS, M. P. G.; SHEKARY, N.; HOUWERS, D. J.; VAN DUYNHOVEN, Y. T. H. P.; VAN DER POEL, W. H. M. Molecular characterizations of human and animal group A rotaviruses in the Netherlands. J. Clin. Microbiol., v. 43, p. 669-675, 2005.

VELAZQUES, F. R.; MATSON, D. O.; CALVA, J. J.; GUERRERO, M. L.; MORROW, A. L.; CARTER-CAMPBELL, $S$. Rotavirus infection in infants as protection against subsequent infections. N. Engl. J. Med., v. 335, p. 1022-1028, 1996.

VENKATARAM, B. V.; CRAWFORD, S.; LAWTON, J. A.; PESAVENTO, J.; HARDY, M.; ESTES, M. K. Structural studies on gastroenteritis viruses. In: Gastroenteritis viruses, edited by D. Chadwick and J. A. Goode, Chichester:John Wiley \& Sons Ltd, 2001, p. 2646.

VENKATARAM, B. V.; CRAWFORD, S.; LAWTON, J. A.; PESAVENTO, J.; HARDY, M.; ESTES, M. K . Structural studies on gastroenteritis viruses. In: Gastroenteritis viruses, edited by D. Chadwick and J. A. Goode, Chichester:John Wiley \& Sons Ltd, 2001, p. 2646.

VENKATARAMAN, S.; ALLISON, D. P.; QI, H.; MORRELL-FALVEY, J. L.; KALLEWAARD, N. L.; CROWE, J. E.; DOKTYCZ, M. J. Automated image analysis of atomic force microscopy images of rotavirus particles. Ultramicroscopy, v. 106, p. 829837, 2006.

VESIKARI, T.; CLARK, H. . F; OFFIT, P. A.; DALLAS, M. J.; DISTEFANO, D. J.; GOVEIA, M. G.; WARD, R. L.; SCHODEL, F.; KARVONEN, A.; DRUMMOND, J. E.; DINUBILE, M. J.; HEATON, P. M. Effects of the potency and composition of the multivalent human-bovine (WC3) reassortant rotavirus vaccine on efficacy, safety and immunogenicity in healthy infants. Vaccine., v. 24, p. 4821-4829, 2006.

VESIKARI,T.; MATSON, D. O.; DENNEHY, P.; VAN DAMME, P.; SANTOSHAM, M.; RODRIGUEZ, Z. DALLAS, M. J.; HEYSE, J. F.; GOVEIA, M. G.; BLACK, S. B.; SHINEFIELD, H. R.; CHRISTIE, C. D.; YLITALO, S.; ITZLER, R. F.; COIA, M. L.; ONORATO, M. T.; ADEYI, B. A.; MARSHALL, G. S.; GOTHEFORS, L.; CAMPENS, D.; KARVONEN, A.; WATT, J. P.; O'BRIEN, K. L.; DINUBILE, M. J.; CLARK, H. F.; BOSLEGO, J. W.; OFFIT, P. A.; HEATON, P. M.; Rotavirus Efficacy and Safety Trial (REST) Study Team. Safety and efficacy of a pentavalent human-bovine (WC3) reassortant rotavirus vaccine. N. Engl. J. Med., v. 5, p. 23-33, 2006. 
VESIKARI, T.; ISOLAURI, E.; DELEM, A.; D'HONDT, E.; ANDRE, F. E.; BEARDS, G. M.;. FLEWETT, T. H. Clinical efficacy of the RIT 4237 live attenuated bovine rotavirus vaccine in infants vaccinated before a rotavirus epidemic. J. Pediatr., v. 107, p. 189194, 1985.

VOLOTÃO, E. M.; SOARES, C. C.; MARANHÃO, A. G.; ROCHA, L. N.; HOSHINO, Y.; SANTOS, N. Rotavirus surveillance in the city of Rio de Janeiro-Brazil during 20002004: detection of unusual strains with G8P[4] or G10P[9] specificities. J. Med. Virol., v. 78, p. 263-272, 2006.

WARD, R. L . Mechanisms of protection against rotavirus in humans and mice. J. Infect. Dis., v. 174, p. S51-S58, 1996, suppl 1.

WARD, R. L.; NAKAGOMI, O.; KNOWLTON, D. R.; MCNEAL, M. M. Evidence for natural reassortants of human rotaviruses belonging to different genogroups. J. Virol., v. 64, p. 3219-3225, 1990.

WOODE, G. N.; BRIDGER, J.; HALL, G. A.; et al. The isolation of reovirus-like agents (rotavirus) from acute gastroenteritis of piglets. J. Med. Virol., v. 9, p. 203-209, 1975.

World Health Organization (WHO). 2000, Geneva. Report of the meeting on the Future Directions for Rotavirus Vaccine Research in Developing Countries.; 9-11, February, 2000.

YEE, E. L.; JIANG, B.; KENDALL, R. S.; HUMPHREY, C.; GLASS, R. I. Group C rotavirus in a pediatric kidney transplant patient with diarrhea. J. Clin. Virol., v. 4, p. 306-308, 2006.

YOLKEN, R. H.; KIM, H. W.; CLEM, T.; WYATT, R. G.; KALICA, A. R.; CHANOCK, R. M.; KAPIKIAN, A. Z. Enzyme-linked immunosorbent assay (ELISA) for the detection of human reovirus-like agent of infantile gastroenteritis. Lancet, v. 2, p. 263-267, 1977.

YOLKEN, R; WEE, S B; EIDEN, J; KINNEY, J; VONDERFECHT, S. Identification of a group-reactive epitope of group $\mathrm{B}$ rotaviruses recognized by monoclonal antibody and application to the development of a sensitive immunoassay for viral characterization. $\mathbf{J}$. Clin. Microbiol., v. 26, p. 1853-1858, 1988.

YOW, M. D.; MELNICK, J. L.; BLATTNER, R. J.; STEPHENSON, W. B.; ROBINSON, N. M.; BURKHARDT, M. A. The Association of Viruses and Bacteria with Infantile Diarrhea. Am. J. Epidemiol., v. 92, p. 33-39, 1970.

ZANARDI, L. R.; HABER, P.; MOOTREY, G. T.; NIU, M. T.; WHARTON, M. Intussusception among recipients of rotavirus vaccine: reports to the vaccine adverse event reporting system. Pediatrics,. v. 107, p. E97, 2001

ZENG, C. Q. Y.; LABBÉ, M.; COHEN, J.; PRASAD, B. V. V.; CHEN, D.; RAMIG, R. F.; ESTES, M. K. Characterization of Rotavirus VP2 Particles. Virology, v. 201, p. 55-65, 1994. 